\title{
The arborescent Linopteris obliqua plant (Medullosales, Pennsylvanian)
}

\author{
ERWIN L. ZODROW, YANAKI G. TENCHOV \& CHRISTOPHER J. CLEAL
}

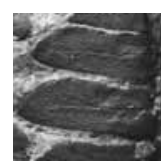

\begin{abstract}
The foliar morphospecies Linopteris obliqua (Bunbury) Zeiller, 1899 was originally based on isolated pinnules from Middle Pennsylvanian (upper Westphalian) strata in the Sydney Coalfield in Nova Scotia, Canada. However, new finds from the type area, including segments of a cauline axis and some fronds, attached juvenile croziers, an attached ovule, and associated pre-pollen organ, allow for a more complete understanding of the whole Linopteris obliqua plant. It was arborescent, $9 \mathrm{~m}$ to $10 \mathrm{~m}$ tall, with fronds $\mathrm{ca} 7 \mathrm{~m}$ long. Ovules of the Hexagonocarpus-type were attached directly to the petiole near the base of the frond, and pre-pollen was produced by Potoniea-type structures. The plant produced seeds and pollen at different times to avoid self-pollination. Ovule production was periodic and accompanied by mass pinnule abscission. The venation, especially the areolate-vein geometry, is relatively invariable within the plant species, and thus provides the typus (blueprint) for distinguishing other linopterid species, especially when combined with two-dimensional probability surfaces, and traditional pinnule morphology. However, the venation must be viewed on the abaxial surface of the pinnules if it is to be reliably interpreted. The mode of vein reticulation is shown to be quite distinct from the anastomosis-pattern seen in the other medullosalean taxa, and is another character that separates the Potonieaceae from the rest of the order. $\bullet$ Key words: Pennsylvanian potonieacean linopterid tree, monoescious, reconstruction.
\end{abstract}

Zodrow, E.L., Tenchov, Y.G. \& CleAL, C.J. 2007. The arborescent Linopteris obliqua plant (Medullosales, Pennsylvanian). Bulletin of Geosciences 82(1), 51-84 (34 figures, 5 tables). Czech Geological Survey, Prague. ISSN 1214-1119. Manuscript received December 6, 2006; accepted in revised version March 5, 2007; issued March 30, 2007. - DOI 10.3140/bull.geosci.2007.01.51

Erwin L.ZZodrow, 503 Coxheath Road,Sydney, Nova Scotia,CanadaB1R 1S1; Erwin_Zodrov@cbu.ca・YanakiG.Tenchov, Geological Institute, Bulgarian Academy of Sciences, G. Bonchev Street, Block 24, 1113 Sofia, Bulgaria $\bullet$ Christopher J. Cleal, Department of Biodiversity and Systematic Biology, National Museum Wales, Cathays Park, CardiffCF10 3NP, UK

Potonieaceae (also variously known as the Parispermaceae or Rachivestitaceae) is a widespread family of medullosalean pteridosperms that has been reported in tropical and northern temperate fossil floras ranging from late Viséan to Kasimovian in age. Much of our knowledge of these plants was summarized by Laveine et al. (1993), who argued that the family originated in China, and progressively migrated westwards towards Euramerica during Serpukhovian and Bashkirian times. Much of the data and the whole-plant reconstruction presented by Laveine et al. (1993) were based on an assemblage of exceptionally-preserved fossils from late Viséan deposits in China. However, most other occurrences of fossils of this group of plants are small fragments, with even the fronds usually disaggregating into their component pinnules and the pollen organs into their component pollen-sac clusters (Laveine et al. 1991). We therefore have little evidence to corroborate whether the reconstruction proposed by Laveine et al. (1993) for the Chinese Viséan representatives of these plants could also be applied to Moscovian Euramerica examples.

In this paper, we document new exceptionally-preserved finds of a Linopteris plant (i.e. a representative of the Potoniaceae bearing foliage with anastomosed veins) from late Moscovian (early Cantabrian) deposits of the Sydney Coalfield, Cape Breton, Canada (Fig. 1). These new fossils include well-preserved samples of foliage, ovules, pollen organs, and some of the cauline parts of the plant that have allowed us to reappraise the whole-plant reconstruction and reproductive biology. We also examine the effects of taphonomy on the foliage, and discuss how these influence our interpretation of it. In order to identify the new specimens, we compare them with the types of Linopteris obliqua (Bunbury) Zeiller, 1899, which also originated from the Sydney Coalfield. Finally, we address some of the consequences for the nomenclature of the fossils and of the whole-plant concept that arises from our work.

\section{Materials}

The new material described in this paper came from six pieces of waste rock in the small open-pit coal mine opera- 


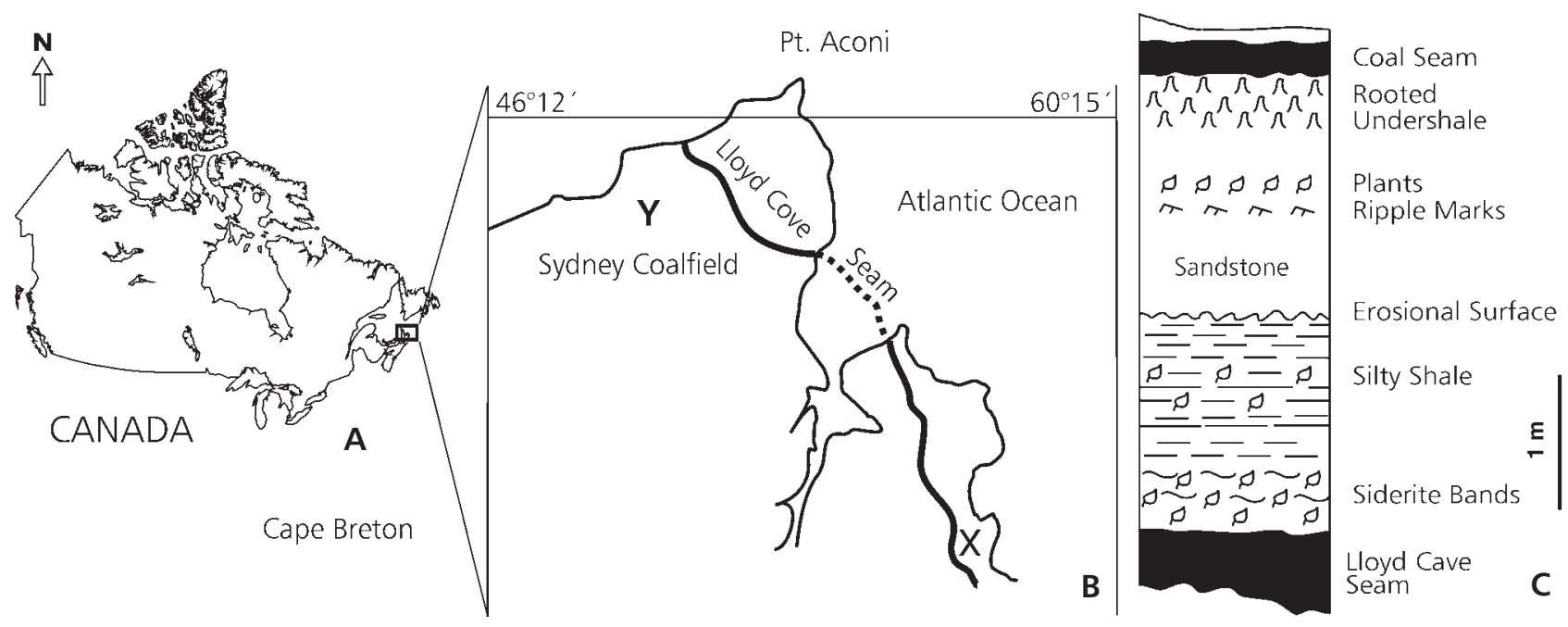

Figure 1. A - Canadian study area. $\bullet$ B - younger part of Sydney Coalfield, Nova Scotia. $\bullet$ C - local stratigraphic column at Brogan's open-pit coal mine at X; Y Prince Mine (Stubbart Seam), both mining operations are closed (2004, 2001, respectively).

ted by Tom Brogan and Sons on Cape Breton Island, Nova Scotia (Fig. 1A, B). These rocks could be tracked back to their origin in the 2-m thick overbank deposit that comprises the fossiliferous roof rocks of the $c a$ 1-m thick Lloyd Cove Seam, which is early Cantabrian (late Moscovian) in age (Zodrow \& Cleal 1985), Fig. 1C. The rocks are classified as grey, silty shale, moderately fissile, with interspersed thin sideritic bands and smaller nodules (see Zodrow 1983). Associated medium-grained muscovitic sandstone also contained some foliar remains. The largest of these silty-shale slabs is $1.7 \mathrm{~m}$ by $1.3 \mathrm{~m}$ and $0.46 \mathrm{~m}$ thick, accessioned as 05-Lst\#0, and it entombed the majority of the data necessary for reconstructing the Linopteris obliqua plant.

The fossil plants are mostly preserved as adpressions (sensu Shute \& Cleal 1986), although a few of the sideritic nodules contained linopterid pinnules preserved by authigenic mineralization (sensu Schopf 1975) - the first record for this mode of preservation in Canadian Carboniferous macrofloras. Included in the copious collections are specimens of medullosalean axes of varying sizes and of two differing topographies, and many isolated ovules (see Zodrow 2002 for a preliminary report on this material). Except for fronds of Alethopteris (Zodrow 2007), virtually no other pteridospermous species were found in the sample area.

Additional material originated from the Stubbart Seam (Prince Mine: Y Fig. 1B, now closed), ca $100 \mathrm{~m}$ above the type Harbour Seam (see Zodrow \& Cleal 1985).

All of the new specimens (accession numbers 04-Z18 to 04-Z29, 04-GW-1, and slab 05-Lst\#0 that yielded specimens 05-Lst\#1 to \#39), slide-mounted cuticles, and negatives are deposited with the Palaeobotanical Collections at the University College of Cape Breton, Sydney, Nova Scotia, for eventual transfer to the national collections at Ottawa, Ontario. Accession numbers, e.g., 980-540, refer to the year 1980 and the $540^{\text {th }}$ shale slab collected during that year. Figures are stored on TIFF files, and camera-lucida drawings are kept as originals. Authenticated L. obliqua samples from the type Harbour Seam are available on request from the senior author (ELZ).

\section{Methods}

The specimens were examined and photographed under oblique light, without coating, immersion or any other means of enhancing contrast. In particular, for observing details of the areolate venation, the direction and angle of incident light had to be varied to avoid misinterpreting closed and intricately interconnected areolae as being open-ended (e.g., Zodrow \& McCandlish 1978, text-figs 6, 8). Indeed, even under higher magnification $(\times 20$ to $\times 25)$, fine details were missed because of improper lighting. Certain pinnules were enlarged to $450-\mathrm{mm}$ length by means of cameralucida equipment to study cross-over areolate venation.

A few L. obliqua pinnules were macerated using traditional techniques (e.g., Cleal \& Zodrow 1989) but only yielded fragmentary cuticles (see also comments by Barthel 1962). However, by isolating coalified pinnules from the matrix without the use of hydrofluoric acid it was possible to examine both surfaces, and to compare these with the impressions in the matrix.

Basic terms for describing frond/petiole features follow Zodrow \& Cleal (1988, text-fig. 2) and Laveine (1997). Venation pattern, one of the most important taxonomic characters in linopterid foliage, is described using the technique employed by Zodrow \& McCandlish (1978). Areolae (vein-meshes) are counted on the concave pinnule side along a straight line erected at right angle to the midvein and at the central part of the pinnule (Fig. 2). Maximal 
areolate length and width dimensions are consistently measured on areola "1", and the shortest ones on "9", respectively. A similar counting technique was used by Bell (1938) for L. obliqua, and by Bocheński (1960) and Tenchov (2004) for Lonchopteris Brongniart. Our measurements were made at $\times 20$ magnification with a zoom-stereo binocular microscope, using intensified, beam-focused fibre-optic illumination, achieving an accuracy of $\pm 0.05 \mathrm{~mm}$.

In hexagonal areolae, the triangular termini are referred to as "hats" (h, see Fig. 3A: inset). Areolae at the midvein may show elongate "tails" instead of a hat that point to the pinnule base (Fig. 3A: a).

The line-of-areola is drawn through points in the hats of the successively shorter areolae from the midvein to the margin (Fig. 3A). The obliquity of the line-of-areola relative to the pinnule margin is variable in a pinnule, i.e. being orthogonal in the pinnule apex and base. Not realized prior to this study is that the number of areolae along a line at right-angles to the midvein is equal or similar to the number of areolae in the line-of-areolae, although Bocheński (1960) commented on such relationship in his study on lonchopterid venation.

Degaging work, combined with oriented sectioning, was used to probe a continuation of exposed coalified layers of hexagonocarpalean casts $(05$-Lst\#38, 39) into the shale matrix in which they were preserved.

\section{Description}

\section{Pinnule morphology}

In the specimens from Brogan's pit (Table 1), the pinnules are stalked with an asymmetric cordate base, longitudinally arched, and margins are invariable curled; length ranges from $4 \mathrm{~mm}$ to $20 \mathrm{~mm}$ and width from $4.5 \mathrm{~mm}$ to $10 \mathrm{~mm}$. Pinnule shapes are round, linguaeform, straightsubtriangular, or slightly falcate-squat falcate, depending on position of attachment along the rachis (see Figs 7, 8, 17); pinnules that are more distal are typically linear, slightly falcate (Fig. 4). Lateral margins are nonparallel in shorter and curvi-parallel in longer pinnules.

The abaxial midvein occupies $80 \%$ of the pinnule length, except in the shorter forms where it is relatively shorter. Venation is anastomosed, with the lines-of-areolae changing from being relatively straight in proximal pinnules to being slightly curved in distal pinnules (Fig. 4). Tailed, elongate areolae lie lengthwise (parallel) with the midvein (Fig. 5). Adjacent to these are elongate areolae of variable shape, including hexagonal and septangular meshes (Fig. 6A-F), and then, towards the pinnule-margin, 5,4 , or 3 -sided areolae occur that gradually decrease in size. Areolae at the pinnule margin are consistently elongate, open-ended.

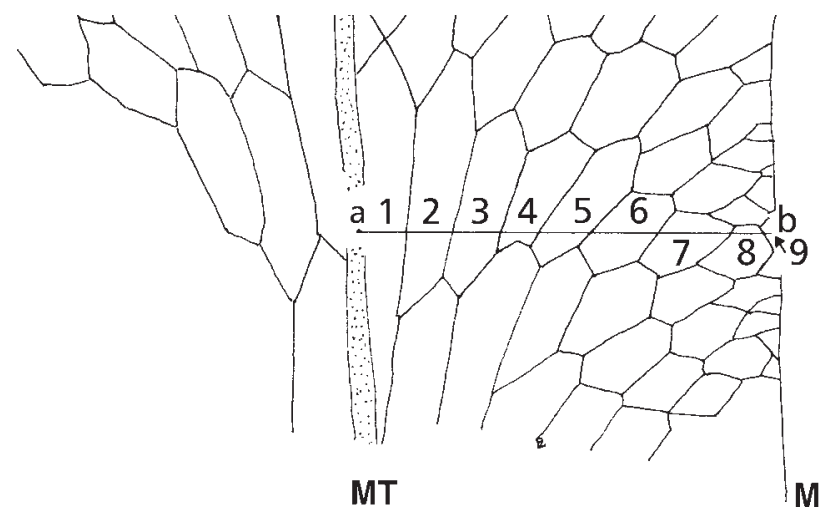

Figure 2. Sampling methodology of areolae in Linopteris obliqua (Bunbury) emend. Near the middle part of the midvein (MT) a line " $a-b$ " at right angle to it is erected to subtend at the concave margin (M). Areolae are counted, e.g., "1 to 9", which intersect with that line. On samples, areolate dimensions for " 1 " and "9" are recorded in Table 1 . The number of areolae intersecting that line on the convex side are also recorded for comparison. Modified after Zodrow \& McCandlish (1978, text-fig. 5).

The number of areolae is generally six, excepting in intercalated and proximal pinnules where it is smaller because of limiting laminate space, and areolae (see Fig. 2) range in length from $1.2 \mathrm{~mm}$ to $2.7 \mathrm{~mm}$, and in width from $0.35 \mathrm{~mm}$ to $0.50 \mathrm{~mm}$ (Table 1 ). Areolae are characterized by densely-distributed punctae.

Morphometric data (Table 1) demonstrate that in 04-Z20b-19-18: (1) the number of areolae is fairly constant over the range of pinnule length-widths, and (2) areolawidth is fairly constant over the range of pinnule lengths (Fig. 7), i.e. the lateral venation pattern is fairly invariant in the sample population. However, in some specimens the measurements of the lengths, widths, and number of areolae are biased because of arching of the pinnules and their curled margins. A bias estimate of about $1 \mathrm{~mm}$ length translates into less than $7 \%$ error for the longest pinnules, and 1 areola at the margin. Pinnule shape and size are clearly dependent on position in the ultimate pinna (Fig. 4).

Specimens from the Stubbart Seam (Prince Mine, Fig. 1), although evidently conspecific with the Brogan's pit material, show some differences in pinnule morphology (see Figs 9, 30). The pinnules attached to the ultimate rachises are $26 \mathrm{~mm}$ long and $18 \mathrm{~mm}$ wide, parallelmargined, with bluntly pointed asymmetric apex, and 8 to 10 elongate-hexagonal areolae. The areolae, 1.9 to $2.2 \mathrm{~mm}$ long and 0.35 to $0.4 \mathrm{~mm}$ wide, lie lengthwise strictly parallel to the midvein, without forming a rosette-like structure at the pinnule base. The intercalated pinnules are $11 \mathrm{~mm}$ long and $6 \mathrm{~mm}$ wide, linguaeform rather than round in outline, and have at the base paired areolae across the midvein, $2.7 \mathrm{~mm}$ long and $0.5 \mathrm{~mm}$ wide.

In summary, it is clear that there is considerable degree of polymorphism in pinnule form in this species, and the morphological designation "typical pinnule" is meaning- 

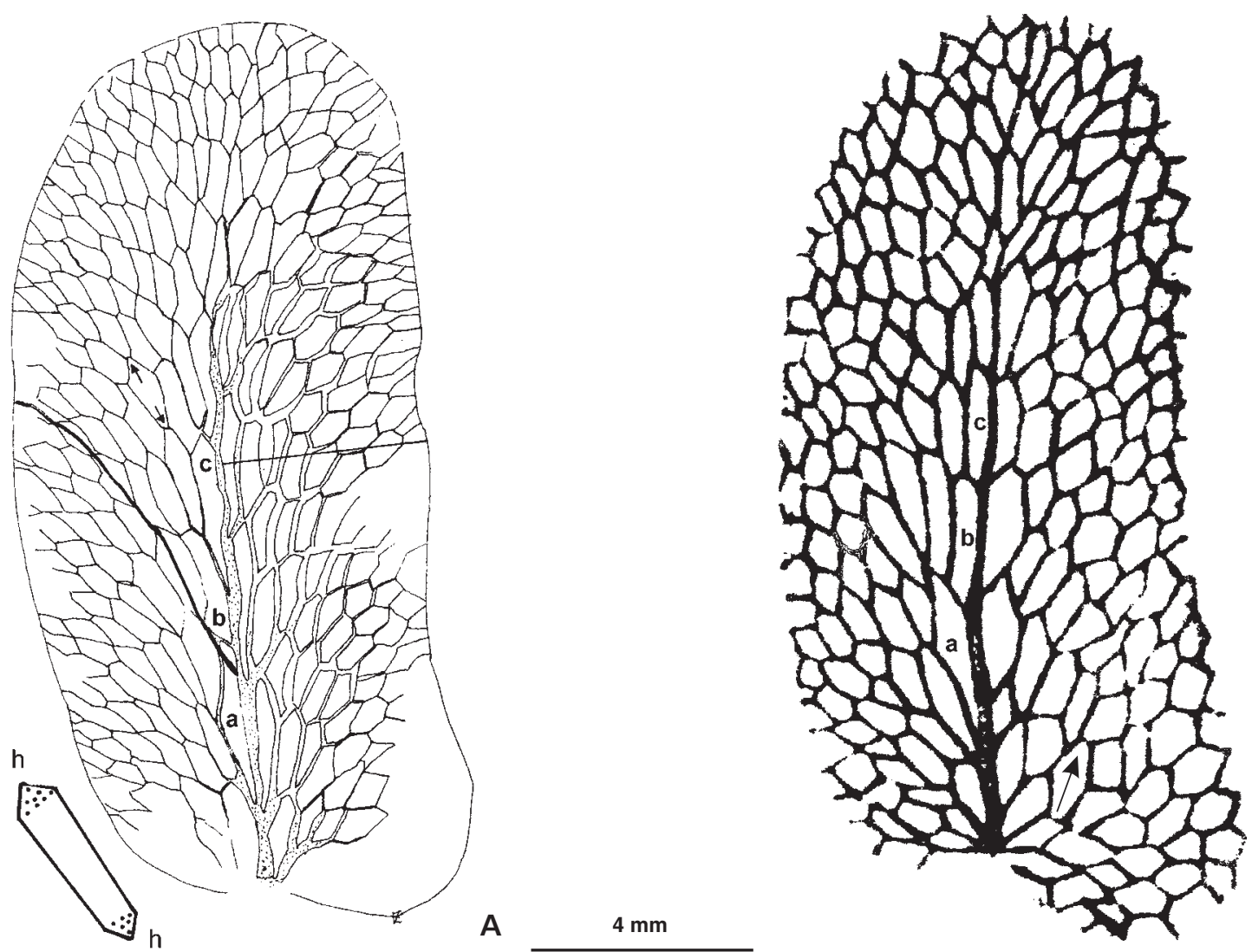

B

Figure 3. Linopteris obliqua (Bunbury) emend. Lectotype 186, adaxial surface; Sydney Coalfield, Cape Breton, Nova Scotia. • A - camera lucida hand-drawing of the lectotype 186. A double-hatted (stippled h-h) areola is shown. The heavy curved line exemplifies a line-of-areola. Areolae are counted along the straight line midvein to margin at "c", see Fig. 2 "a-b" (Table 1). Small arrows point to crossover connections which cause the formation of "three-sided" hats. • B - lithograph by Bunbury (1847, fig. 2B) of the same specimen. "a- c" corresponding areolate areas.

less. Rather, we prefer to refer to the relative frequency of the different pinnule morphotypes.

Moreover, strictly elongate-hexagonal areolae are not the most frequently occurring, as compared with pentagonal, tetragonal, or even trigonal areolae. Some, however, are even septangular (see Bunbury's figs 2B, 3A, B, 6G), which is not referenced in the literature on linopterid taxonomy.

\section{Penultimate pinnae}

A number of bipinnate segments were found in the Brogan's pit assemblage the largest is $230 \mathrm{~mm}$ long with a 4-mm wide rachis (Fig. 7). All rachises are densely punctate and striate. Although partly eroded, the penultimate rachis shows sub-oppositely attached ultimate pinnae, between which occur intercalated pinnules. The intercalated pinnules are $4 \mathrm{~mm}$ to $5 \mathrm{~mm}$ long, and vary from linguaeform to sub-circular shapes. The ultimate pinnae are curved and fan-out, preserved for a maximum length of $150 \mathrm{~mm}$ and width of $40 \mathrm{~mm}$, and variably ovate-oblong in outline. The distal parts of adjacent pinnae occur at different levels in the rock matrix, separated from each other by several mm of intervening sediment.
Two other fragments of penultimate pinnae were found, where the rachises are $5 \mathrm{~mm}$ to $6 \mathrm{~mm}$ wide, and preserved for a length of $30 \mathrm{~mm}$ and $70 \mathrm{~mm}$, respectively. Attached ultimate pinnae reach a length of $190 \mathrm{~mm}$ (Fig. 8). Rachises are striate and densely interspersed with punctae. The ultimate pinnae are linear in outline, but taper proximally, show areolate geometry (Fig. 5), and morphometrics (Table 1) comparable to the structure in Fig. 7. In all of these three specimens, the pinnules are attached to the upper part of the ultimate rachis, which together with their arched nature, would result in the ultimate pinnae having a "winged" cross section.

Similar penultimate linopterid pinnae were found at the Stubbart Seam (Prince Mine, Fig. 1B: Y), except that the penultimate rachises appear fluted and show no evidence of being punctate (Fig. 9).

\section{Antepenultimate pinnae}

Two detached, apparently tripinnate rachises, with parallel, longitudinal striae and densely punctate (Table 2), were found lying on top of each other entombed in the largest 
Table 1. Morphometric data of Linopteris obliqua (Bunbury) emend. Measurements in mm. Abbreviations: $\mathrm{n}$ - number of samples, and number keyed to Figs $4,7,8$, no - not obtainable because of local erosion, * - for definition see Fig. 2.

\begin{tabular}{|c|c|c|c|c|c|c|c|c|c|}
\hline \multicolumn{3}{|c|}{ Areola: at midvein * } & \multicolumn{2}{|c|}{ Near concave pinnule margin } & \multicolumn{2}{|c|}{ No. of areolae } & \multicolumn{3}{|c|}{ Pinnule } \\
\hline $\mathbf{n}$ & Length & Width & Length & Width & Convex & Concave * & Length & Width & $\mathbf{L} / \mathbf{W}$ \\
\hline \multicolumn{10}{|c|}{ Lectotype 186; abaxial, Fig. 25} \\
\hline 1 & 2.5 & 0.30 & 0.75 & 0.40 & 9 & $8-9$ & 16 & 7 & 2.28 \\
\hline \multicolumn{10}{|c|}{ Brogan's open-pit mine } \\
\hline \multicolumn{10}{|c|}{ 04-Z20b, abaxial, Fig. 7} \\
\hline 2 & 1.2 & 0.40 & no & no & $6 ?$ & 7 & 14 & 5 & 2.80 \\
\hline 3 & 2.6 & 0.50 & 0.85 & 0.40 & 6 & 6 & 17 & 5.5 & 3.09 \\
\hline 4 & 1.3 & 0.40 & 0.65 & 0.30 & 6 & 6 & 15 & 5 & 3.00 \\
\hline 5 & 2.7 & 0.50 & 0.60 & 0.25 & 5 & 6 & 16.5 & 5.5 & 3.00 \\
\hline 6 & 2.0 & 0.35 & 1.0 & 0.40 & $5 ?$ & 6 & 15 & 5 & 3.00 \\
\hline 7 & 2.2 & 0.40 & 0.75 & 0.25 & 6 & 6 & 16 & 5 & 3.20 \\
\hline 8 & 1.8 & 0.35 & 0.95 & 0.35 & 5 & 5 & 10 & 5 & 2.00 \\
\hline 9 & no & no & no & no & no & no & 4 & 5 & 0.80 \\
\hline 10 & 1.7 & 0.50 & no & no & no & 6 & 11.5 & 6 & 1.91 \\
\hline 11 & 2.0 & 0.35 & no & no & no & 7 & 15.5 & 6 & 2.58 \\
\hline 12 & 2.4 & 0.40 & no & no & no & 7 & 17.5 & 6.5 & 2.46 \\
\hline 13 & no & no & no & no & no & $5 ?$ & 15 & 4.5 & 3.33 \\
\hline 14 & 1.7 & 0.40 & no & no & $6 ?$ & 7 & 14 & 6.5 & 2.15 \\
\hline \multicolumn{10}{|c|}{ 04-Z19, abaxial } \\
\hline 15 & 1.7 & 0.35 & no & no & no & 6 & 11 & 6 & 1.83 \\
\hline 16 & no & no & no & no & $5 ?$ & $6 ?$ & 19 & 7 & 2.71 \\
\hline 17 & no & no & no & no & $6 ?$ & no & 16 & 7 & 2.28 \\
\hline \multicolumn{10}{|c|}{ 04-Z18, abaxial } \\
\hline 18 & 2.0 & 0.35 & no & no & 7 & 7 & 16 & 6 & 2.66 \\
\hline 19 & 1.5 & 0.35 & no & no & no & 6 & 9 & 6 & 1.50 \\
\hline \multicolumn{10}{|c|}{ 04-Z25a, abaxial, siderite-preserved, Fig. 24} \\
\hline 20 & $1.5 ?$ & $0.75 ?$ & no & no & no & $6 ?$ & 20 & 10 & 2.00 \\
\hline \multicolumn{10}{|c|}{ Harbour Seam } \\
\hline \multicolumn{10}{|c|}{ 982-201, adaxial, Fig. 31B } \\
\hline 21 & 2.0 & 0.50 & 0.40 & 0.30 & 10 & 10 & 27 & 10 & 2.70 \\
\hline \multicolumn{10}{|c|}{ Range (excluding type 186) } \\
\hline & $1.2-2.7$ & $0.35-0.75 ?$ & $0.40-1.0$ & $0.25-0.40$ & $5(6)-10$ & $5(6)-10$ & $4-27$ & $5-10$ & $0.30-3.33$ \\
\hline \multicolumn{10}{|c|}{ Average (excluding type lectotype 186 ) } \\
\hline & 1.9 & 0.43 & - & - & - & - & 15 & 6 & 2.60 \\
\hline
\end{tabular}

shale slab (Fig. 10). The longer tripinnate rachis is preserved for a length of $1.08 \mathrm{~m}$. It is curved and tapers from a width of $22 \mathrm{~mm}$ at the base to $14 \mathrm{~mm}$ to $15 \mathrm{~mm}$ near the top (Fig. 10A). Alternately attached (secondary) rachises show flared bases which are photographically documented for the trunk in Fig. 19. The secondary rachises occur at intervals decreasing distally from $310 \mathrm{~mm}$ to $120 \mathrm{~mm}$; the proximal rachises are $7 \mathrm{~mm}$, and the more distal $5 \mathrm{~mm}$ wide. None of the secondary rachises shows evidence for preserved bases of higher-order rachises that could bear lamina. The segment is assumed to have been originally tripinnate, based a comparison with the previously described tripinnate structure. Fig. 10B represents the shorter of the two which is preserved for a length of $0.81 \mathrm{~m}$. The lowest- order rachis is straight, and $22 \mathrm{~mm}$ wide in its most proximal part, tapering to $17 \mathrm{~mm}$ distally. Secondary rachises with a flared base are alternately attached at distances that vary from $47 \mathrm{~mm}$ to $294 \mathrm{~mm}$, approaching opposition. Two of these secondary rachises each bear the bases of higherorder rachises.

These two specimens are assumed to be parts of antepenultimate frond segments, based on their width compared to the secondary rachises shown in Fig. 19, and the basal width of the highest-order rachises (arrowed in Fig. 10B), compared with those of the ultimate rachises shown in Fig. 7. The wider spacing of the rachises in the curved specimen Fig. 10A suggests that it originated from a more proximal position in the frond compared to the straighter specimen. 


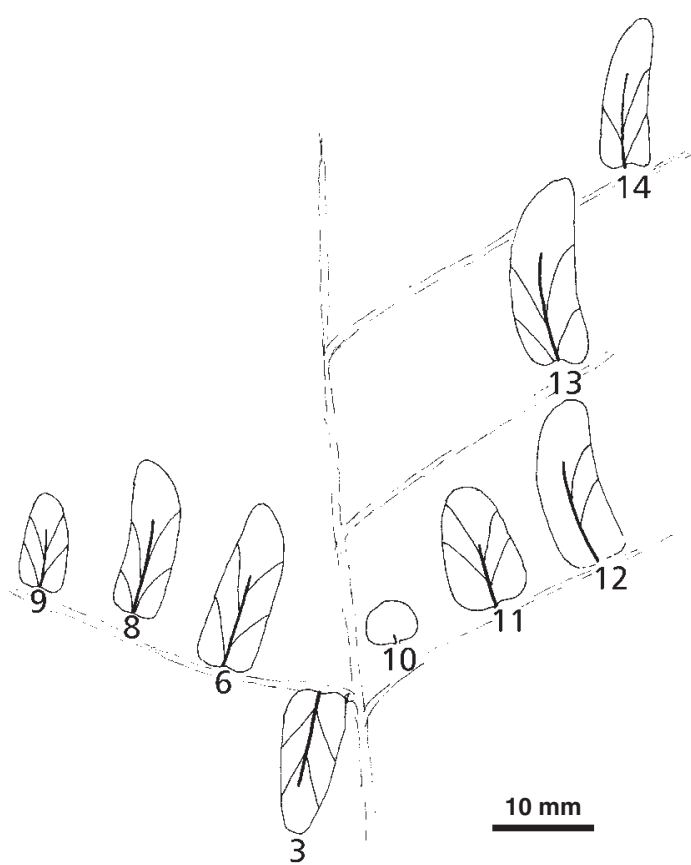

Figure 4. Linopteris obliqua (Bunbury) emend., specimen 04-Z20b, Lloyd Cove Seam, Sydney Coalfield, Cape Breton, Nova Scotia; summary of pinnule shapes together with lines-of-areola. Numbers " 3 to 14 " are keyed to Fig. 7, and to Table 1. Rachial outline is faintly indicated.

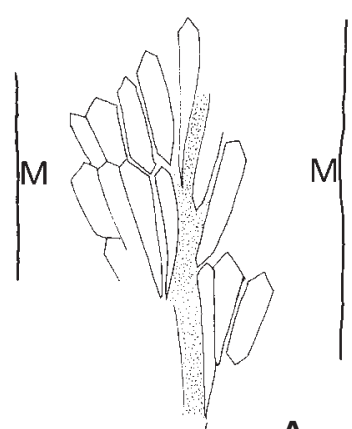

A

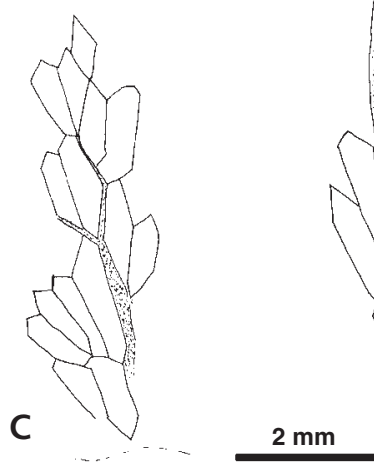

Figure 5. Linopteris obliqua (Bunbury) emend., Lloyd Cove Seam, Sydney Coalfield, Cape Breton, Nova Scotia; areolate structure at midveins. - A - more frequent form (specimen 04-Z20b) and pinnule "7" (see Fig. 7). • B - frequent form (specimen 04-Z20b) pinnule "12" (see Fig. 7). $\bullet \mathrm{C}-$ linguaeform pinnule ( $8 \mathrm{~mm}$ long), specimen $04-\mathrm{Z} 18$. $・ \mathrm{D}-$ frequent form, specimen 04-Z18. Stippled areas represent the midvein, and $\mathrm{M}$ is the pinnule margin.
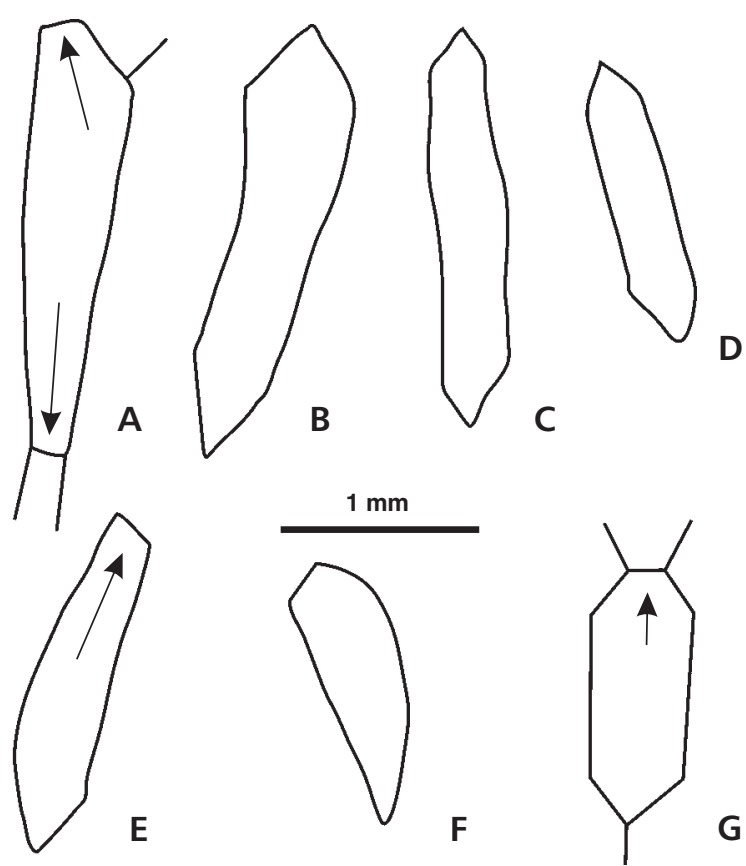

Figure 6. Linopteris obliqua (Bunbury) emend., specimen 04-Z20b, Lloyd Cove Seam, Sydney Coalfield, Cape Breton, Nova Scotia. • A-F illustrating size and shape variation in hexagonal areolae at the midvein (i.e. "1" in Fig. 2). • G-cross-over connection observed near pinnule margin and apex. Arrows point to the cross-over connections.

\section{Trifurcating axes}

Associated with the penultimate pinnae at Brogan's pit are abundant segments of axes up to $100-\mathrm{mm}$ wide. As is the case with the rachises of the penultimate pinnae, they are covered with dense longitudinal ridges, striae, and abundant coarse punctae.

One of these axes, preserved on a large $(1 \mathrm{~m} \times 0.6 \mathrm{~m} \times$ $0.4 \mathrm{~m}$ ) silty-shale slab, was originally part of a quadripinnate frond-segment. The main axis was originally preserved for a length of $c a 0.8 \mathrm{~m}$, but after preparation this was reduced to only $0.57 \mathrm{~m}$ (Figs $11-13$ ). The main axis "I" (petiole) Fig. 12A is trifurcating at "T" (Fig. 11), being inclined to the fracture plane at $\mathrm{ca} 10^{\circ}$ that shows rachis "II". "I" is $45 \mathrm{~mm}$ wide, straight, and with slightly concave margins, and the two lateral rachises ("II") are 19 and $20 \mathrm{~mm}$ wide, respectively, straight, and parallel-sided, oppositely placed, and the angle of separation is $100^{\circ}$. These secondary rachises ("II") bear punctate tertiary rachises (e.g., "III" in Fig. 12) which are 9 mm wide and lie at near to right-angles to the secondary rachises. These tertiary rachises in turn show the bases of what we assume are quaternary rachises (e.g., arrowed at "IV" on Fig. 12A).

A piece, probably split-off from a main axis (embedded in the same block in Fig. 13) shows what may be a laminate structure, $20 \mathrm{~mm}$ long and $30 \mathrm{~mm}$ wide (Fig. 14).

Another axis $1.7 \mathrm{~m}$ long (Fig. 15A and B), with parallel, longitudinal striae and densely distributed punctae 


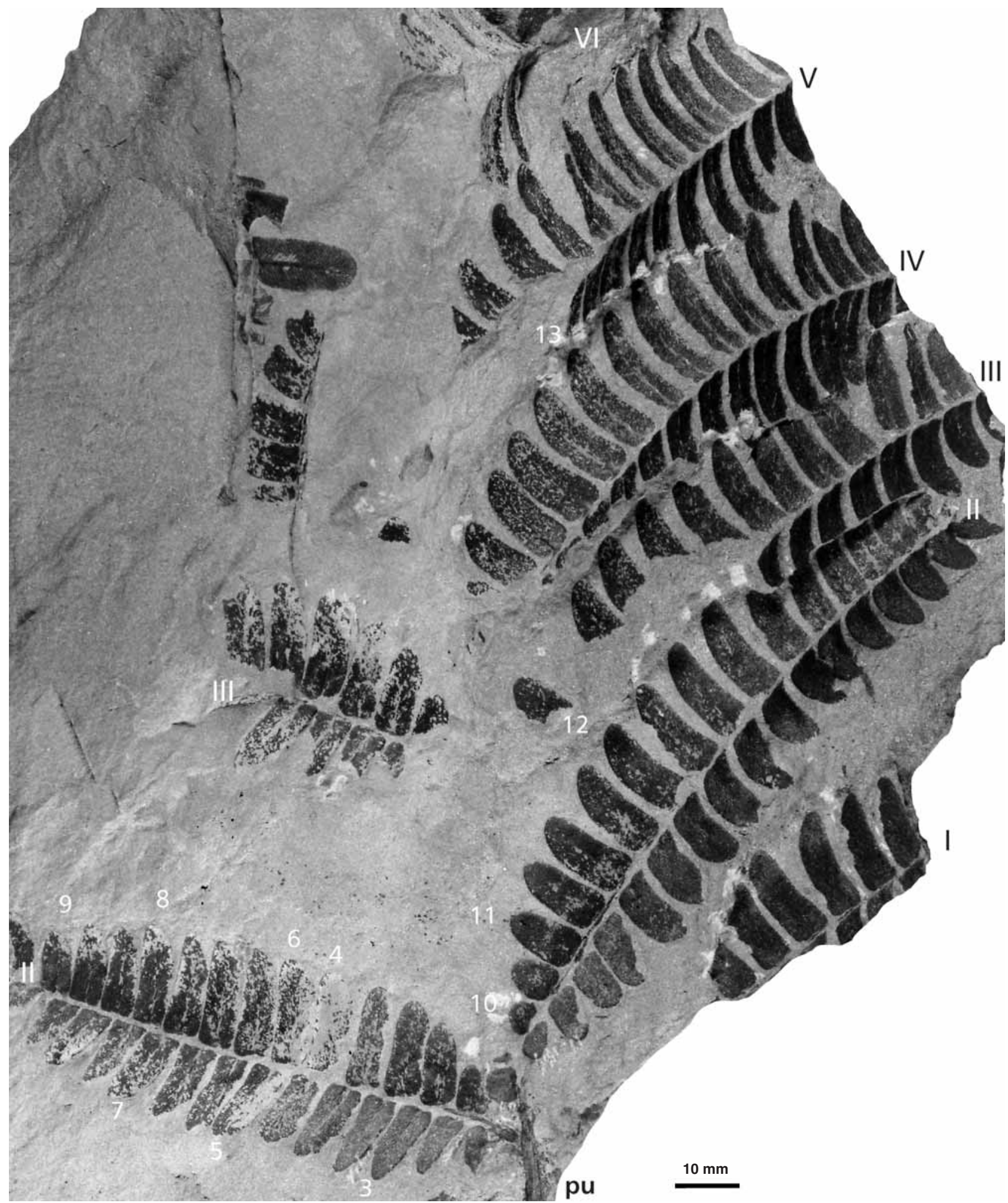

Figure 7. Linopteris obliqua (Bunbury) emend., specimen 04-Z20b, Lloyd Cove Seam, Sydney Coalfield, Cape Breton, Nova Scotia; interpreted penultimate rachis "pu" enhanced by hand with India ink. "I to VI" successive superposition of ultimate pinnae, each separated by several mm of sediments; numbers " 3 to 14 " are keyed to Table 1, and " $3,6,8,9,10$ to 14 " and to Fig. 4. 


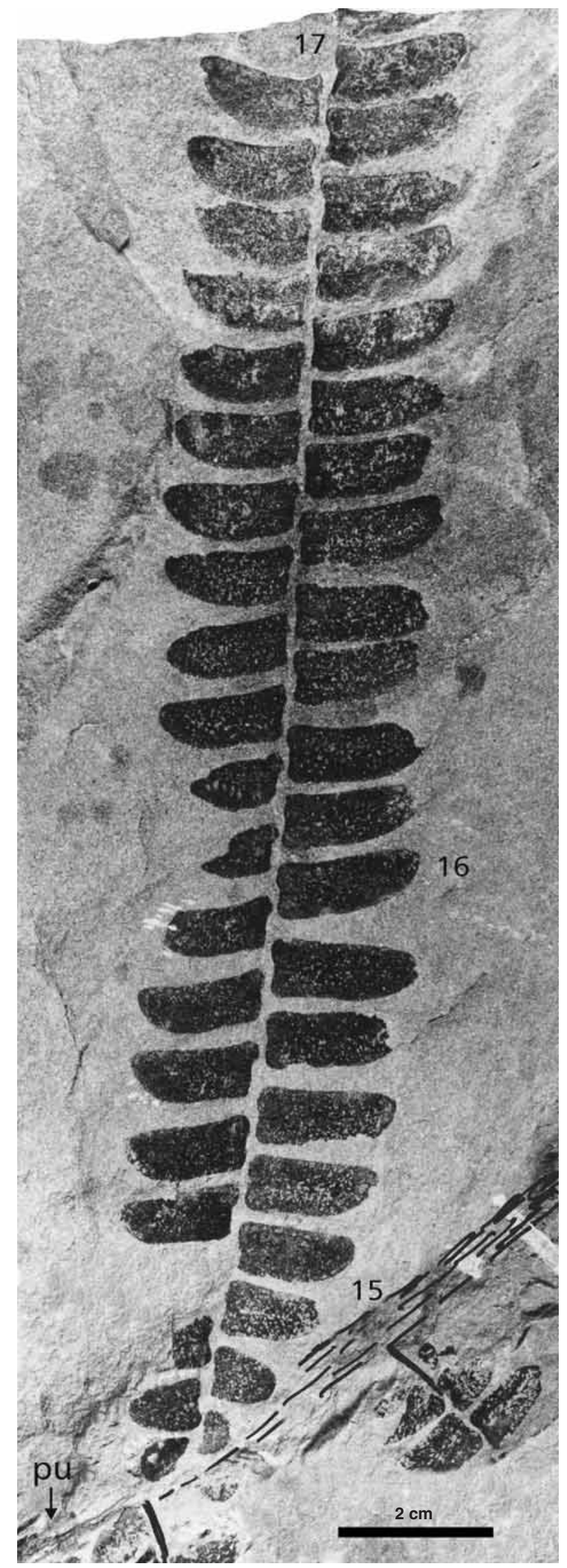

(Table 2) shows a sub-trifurcation similar to that seen in Figs 11-13. The axis tapers distally from a width of 65 $\mathrm{mm}$ to $45 \mathrm{~mm}$, and the trifurcation occurs towards the distal end ( $c$ a $1.22 \mathrm{~m}$ from the base). Careful field degaging along the axis revealed no attached rachises or laminate structures.

\section{Juvenile foliage}

Fig. 16 documents a $c a 0.2 \mathrm{~m}$ long axial-branching system that is associated with the other specimens from Brogan's pit. All axes are coarsely punctate and densely striate (Table 2). The main axis is approximately $25 \mathrm{~mm}$ wide in its most proximal part, and on its left-hand side there is attached an $11 \mathrm{~mm}$ wide subsidiary axis. Above this branch, the main axis continues at a reduced width (15 to $16 \mathrm{~mm}$ ). About $50 \mathrm{~mm}$ further along the main axis, another subsidiary axis, 8 to $9 \mathrm{~mm}$ wide, occurs on the left-hand side, and this overlies the more-proximal subsidiary axis. Judging from the displacement of the line of the main axis at the arrowed-point shown on Fig. 16, the possibility of a subsidiary axis exists on the right-hand side.

The more distal of the two preserved subsidiary axes is twisted, and shows two attached unfurling juvenile pinnae, with one (the more proximal) being adpressed upon the other. The completely exposed juvenile pinna is ca $80 \mathrm{~mm}$ long with an intact, curved terminal part. The rachises bear a profusion of short, stocky spines, $c a 600 \mu \mathrm{m}$ to $1,000 \mu \mathrm{m}$ in length (Fig. 16). The juvenile pinna has between eight and ten unfurling subsidiary pinnae (the exact number is difficult to ascertain as they are closely packed in the distal part of the structure). Each of these is $10 \mathrm{~mm}$ to $12 \mathrm{~mm}$ long and on its concave side bears the basal parts of striate pinnules, with midveins attached to the rachis (e.g., Fig. 18); punctae could not be observed. Completely individualized pinnules are not evident, but it appears that at this developmental stage they were slender, $3 \mathrm{~mm}$ to $4 \mathrm{~mm}$ long and already longitudinally arched. A few fully-developed areolae are preserved, complete with hats, $350 \mu \mathrm{m}$ long and $55 \mu \mathrm{m}$ wide (Fig. 18). Less developed areolae are $c a 100 \mu \mathrm{m}$ long and $60 \mu \mathrm{m}$ to $66 \mu \mathrm{m}$ wide, slender-elongate and without the hexagonal habit. Generally, the areolae decrease in size distally from the midvein, and also change shape away from elongate-hexagonal to more isodiametric. Whether the areolae are openended at the margin or not could not be ascertained.

Figure 8. Linopteris obliqua (Bunbury) emend., specimen 04-Z19, Lloyd Cove Seam, Sydney Coalfield, Cape Breton, Nova Scotia; an attached $190 \mathrm{~mm}$ long, near-complete elongate-ovate shaped ultimate pinna. Penultimate-pinna rachis "pu" is emphasized by hand India inking. See Fig. 17 for details of intercalated pinnules on the penultimate-pinna rachis. Numbers " 15 to 17 " are keyed to Table 1. 


\section{Punctate axes}

Table 2 presents a general overview of data on the punctae seen on axes of different widths, but it is not a statistical analyses with probability-circumscribed inferences. We can only say that these three structures (Figs 10, 15, 16, 19), and indeed all axes uncovered in the largest shale slab 05-Lst\#0, and some from elsewhere in the sample area, have a surface characterized by longitudinal ridges or striations that are mutually parallel, and invariably interspersed with punctae shown in negative relief that may interrupt the striae. Punctae are of variable dimension and shape. In any particular axis, they may vary in diameter from $<0.1 \mathrm{~mm}$ to $2.5 \mathrm{~mm}$, with the smallest being invariable round and the larger ones variably round to oval. It appears that a correlation exists between the variability of the largest puntae per axis and the diameter of the axes, where the trunk shows the largest punctae.

In summary, it is reasonable to assume that (1) the shared topographical features point to a common linopterid origin for these structures listed in Table 2, and (2) the larger punctae $(>1 \mathrm{~mm})$ represent bases of spines.

\section{Cauline axis}

A fragmentary trunk (stem) is preserved for a length of $1.16 \mathrm{~m}$ and width of $0.21 \mathrm{~m}$ in the largest shale slab (Figs 19, 20). As an adpression, it consists of a sequence of layers:

(1) an outer coalified layer showing heavy covering of bases of punctae; (2) an impression of longitudinal striations interspersed with coarse punctae; (3) wavy longitudinally-arranged impressions of cortical sclerentymatous fibrous bundles; and (4) an innermost coalified layer. This sequence is then repeated in reverse order towards the rock matrix, probably representing a compressed cross section of the trunk. The coalified layers are impregnated with sulfide minerals, mostly pyrite.

The trunk shows two organically-connected petioles, all of which are striate and coarsely punctate (Table 2). The upper petiole (\#1, Fig. 20) is preserved for a length of $0.54 \mathrm{~m}$, and a width of $80 \mathrm{~mm}$. On removing an overlying, detached 72-mm wide petiole (\#9, Fig. 20) that is traceable for $1.19 \mathrm{~m}$ across the largest silty-shale slab, the lowermost attached petiole (\#10, Fig. 20) was exposed. It is $73 \mathrm{~mm}$ wide and is seen clearly broken off at $0.20 \mathrm{~m}$ from its point of attachment, as shown by the steep angle at which it lies to the bedding plane. The base of each petiole flares out considerably to a width of 100 $\mathrm{mm}$ to $120 \mathrm{~mm}$, with fibrous strands extending from the trunk into each petiole. There is no evidence for branching rachises nor for laminate structure attached to the petioles.

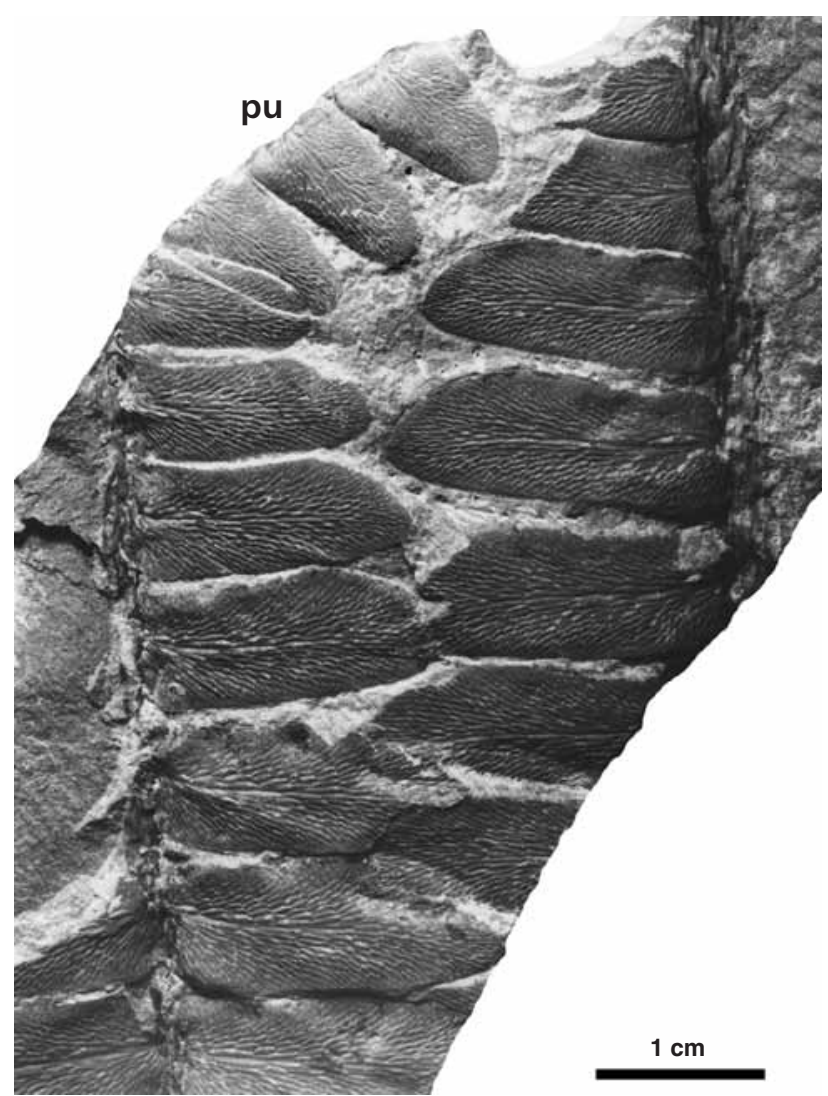

Figure 9. Linopteris obliqua (Bunbury) emend., specimen 985-212, Stubbart Seam (Prince Mine), Sydney Coalfield, Cape Breton, Nova Scotia; a fragmentary-bipinnate structure with longer pinnules, linguaeformintercalated pinnules, and fluted ultimate rachises. "pu" indicates the eroded penultimate-pinna rachis.

\section{Ovules}

On the lowermost attached petiole \#10 in Fig. 20, a thickly coalified ovule is seen in an axillary position (Fig. 21A, B). It is $24 \mathrm{~mm}$ long and $14 \mathrm{~mm}$ wide, ovate in shape, and slightly eroded on the right-hand side. Visible are three? longitudinal ribs, slightly curved upwards, which makes it possible to observe much of its flattened distal (micropylar) end which has circular structures that express the curvature in each rib (Fig. 22A). Removal of the thicker outer coalified layer exposed densely distributed punctae at its flattened end. Preserved is also a flange-like structure about the ovule. Undisputable organic attachment could not be demonstrated because of some fragmentation.

Both at the Brogan's pit (Lloyd Cove Seam), and the Harbour Seam (type seam for L. obliqua), single, detached ovules are associated with linopterid foliage, but not exclusively so (Zodrow 2002, fig. 16d). They occur either as incomplete casts (hemispheric-like, round: Figs 22B, 23A), or as incomplete molds, compressed to show $1 \mathrm{~mm}$ to 2 -mm wide flanges. The outline is ovoid-acuminate, length ranges from $17 \mathrm{~mm}$ to $24 \mathrm{~mm}$ and total width from $12 \mathrm{~mm}$ 
Table 2. Survey data of punctae on linopterid axes per $1 \mathrm{~cm}$ square unit area. Sydney Coalfield, Nova Scotia, Canada.

\begin{tabular}{|c|c|c|c|c|c|c|}
\hline \multirow{2}{*}{$\begin{array}{l}\text { Point of sampling } \\
\text { and specimens }\end{array}$} & \multirow{2}{*}{$\begin{array}{l}\text { Axial width } \\
\text { mm }\end{array}$} & \multirow[b]{2}{*}{ Axial designation } & \multicolumn{4}{|c|}{ Punctae (trichomes/spines) } \\
\hline & & & Unit area & $\begin{array}{c}\text { Size range } \\
\text { mm }\end{array}$ & $\mathbf{n}$ & Shape(s) \\
\hline \multicolumn{7}{|l|}{ Rachis (Fig. 17) } \\
\hline 04-Z19 & 5 & isolated pen ultimate rachis & $22+$ & 0.1 to $<0.1$ & 22 & round \\
\hline \multicolumn{7}{|c|}{ Juvenile frond (Fig. 16) } \\
\hline 04-GW-1 & 20 & frond rachis & 7 to 10 & 0.4 to 1.0 & 27 & elongate \\
\hline \multicolumn{7}{|c|}{ Trifurcating frond (Fig. 12) } \\
\hline \multirow[t]{4}{*}{$04-\mathrm{Z} 22 \mathrm{~b}$} & 29 & main axis, distal & 7 to 9 & 0.1 to 0.8 & 16 & round \\
\hline & 40 & proximal & 7 to 12 & 0.1 to 1.2 & 19 & round to oval \\
\hline & 20 & left branch & 15 to 23 & 0.1 to 0.7 & 38 & round \\
\hline & 20 & right branch & 21 to 23 & 0.1 to 0.5 & 44 & round \\
\hline \multicolumn{7}{|c|}{ Trunk and petioles (Figs 10, 19) } \\
\hline 05-Lst\#2 & 200 & trunk & 4 to 9 & 0.8 to 2.5 & 35 & uniformly round \\
\hline n0 05-Lst\#1 & 80 & upper petiole & 9 to 40 & 0.1 to 2.5 & 79 & round to oval \\
\hline 05-Lst\#10 & 65 & lower petiole & 6 to 13 & 0.3 to $2.0 ?$ & 19 & rounds to oval \\
\hline 05-Lst\#11 & 50 & isolated petiole & 6 to 18 & 0.1 to 2.0 & 73 & round to oval-elongate, respectively \\
\hline \multicolumn{7}{|l|}{ Rachis (Fig. 10A, B) } \\
\hline 05-Lst\#25 & 19 & isolated antepen-ultimate rachis & $22-35$ & 0.2 to 1.0 & 57 & round to oval \\
\hline 05-Lst\#27 & 7 & isolated antepen-ultimate rachis & 18 & 0.1 to 0.9 & 8 & round to oval \\
\hline
\end{tabular}

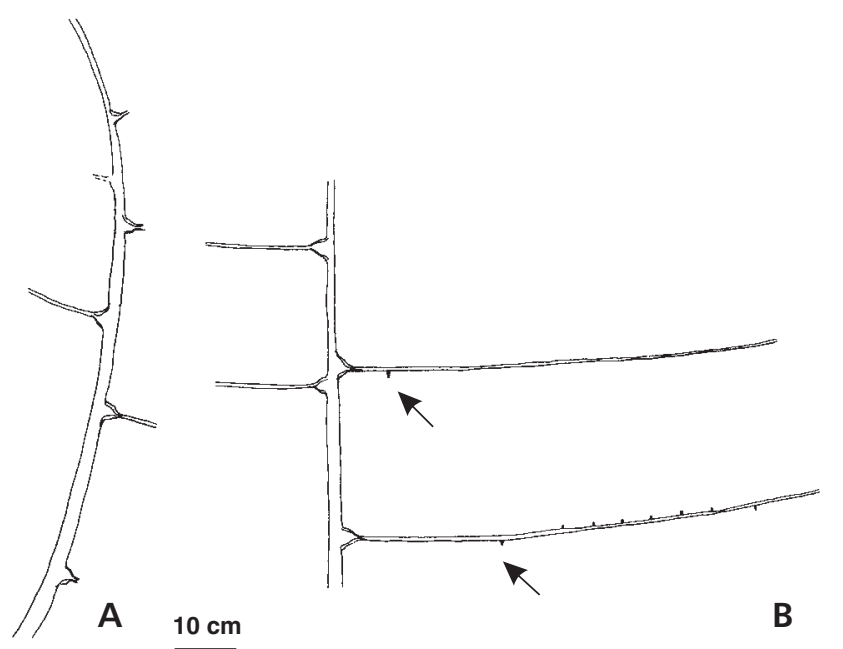

Figure 10. Detached antepenultimate rachises, on slab 05-Lst\#0. Lloyd Cove Seam, Sydney Coalfield, Nova Scotia. $\bullet$ A - naturally curved rachis with alternately attached penultimate rachises. 05-Lst\#25. $\bullet \mathrm{B}-$ straight rachis with alternately and sub-oppositely attached penultimate rachises. Arrows point to bases of ultimate rachises. 05-Lst\#27. Note swelling of rachial bases, slightly exaggerated. Based on field mapping, aided by photographs.

to $15 \mathrm{~mm}$. Surfaces are micro-reticulate. At most three major, longitudinal ribs, each 4 to $5 \mathrm{~mm}$ wide are present, and one or two faintly outlined ribs are seen confined, however, to one-half or so of the ovular length. At most two of what appears to be commissures are exposed (see Taylor 1965), summary Table 3.

Of the $\mathrm{ca} 80$ ovules collected at Brogan's pit, most of them from the largest shale slab 05-Lst\#0, one is a partial mold that unambiguously shows six-fold symmetry, which apparently has not been previously identified in compressions (Laveine et al. 1993, p. 108). The hexagonal symmetry exists both in respect to ribs and commissures, where the latter bisect the major ribs (Figs 22C, 23B). Several overprinted or juxtaposed ovules were also found (see Zodrow 2004).

Of biological significance (see later) is that in the largest shale slab (05-Lst\#0), these hexagonal-symmetric ovules co-occur in bedding planes with dense accumulation of only L. obliqua pinnules (Fig. 23C). Four of these successive "biodepositional" bedding planes were observed, each separated by a 40 to $45 \mathrm{~mm}$ thick afossiliferous silty shale band.

\section{Pollen organs}

In contrast to the abundant ovules, pollen organs are exceedingly scarce, but a few small fragments were found in the largest shale slab (05-Lst\#0). These show the pollen-sac structure characteristic of the morphogenus Potoniea Zeiller. Significantly, the pollen organs were preserved in a separate layer within the largest shale slab from the biodepositional foliage-ovules layers.

\section{Taphonomy}

Two main taphonomic influences have been identified that acted on the linopterid foliage to alter its appearance from how it looked in life. For adpressions, it is to do with the 

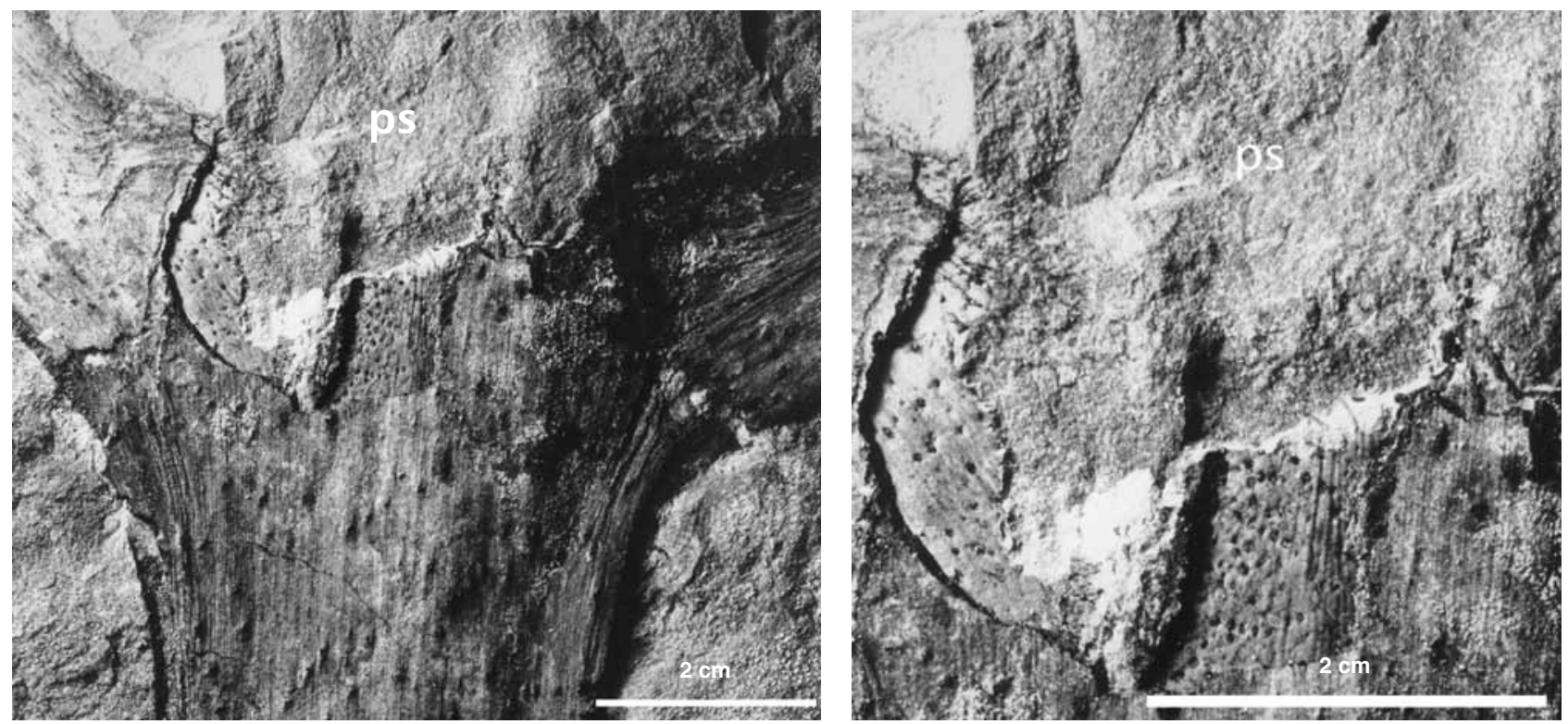

Figure 11. Field photograph, Lloyd Cove Seam, Sydney Coalfield, Cape Breton, Nova Scotia; detail of pseudocounter part of Fig. 13. Note the buried prolongation at "ps", and strong punctate, and longitudinal striate topography. The right fork appears preserved (now exposed) below the bedding plane that contains the left fork. Illumination is from the left.

texture and composition (especially clay mineralogy and its varied diagenesis) of the clastic rocks. For the authigenic mineralization, it was the crystallization pressure of precipitating siderite during diagenesis in a reducing environment.

\section{Effect on adpressions}

Taphonomic loss/gain information (see summary: Wilson 1988) was determined by studying adaxial and abaxial topographies of compressions, and the impressions that they leave in the rock when the coalified tissue is removed. Two sets of specimens were studied. The first was from the Lloyd Cove Seam, preserved in the silty shale mainly composed of mica/illite/kaolinite, with 22 weight-percent detrital quartz that is maximally $80 \mu \mathrm{m}$ in diameter (Zodrow et al. 2000). The compressed pinnules, $15 \mathrm{~mm}$ long and $5 \mathrm{~mm}$ wide, are $20 \mu \mathrm{m}$ to $25 \mu \mathrm{m}$ thick, and could physically be lifted intact from the rock matrix. This allowed both compression surfaces to be observed, as well as the impression left by the abaxial surface of the coalified tissue. The second set of specimens was found associated with the Stubbart Seam (Fig. 1B-Y) in shale composed of mica/illite/ and 16 weight-percent quartz that is maximally $8 \mu \mathrm{m}$ in diameter (Zodrow \& Mastalerz 2001). These specimens showed the abaxial surface of the compression. It was physically impossible to detach the coalified tissue in this second set of specimens, and so it was removed by maceration with Schulze's solution. This procedure invariably fragmented the compressions beyond recognition, but re- vealed the underlying impression caused by the adaxial surface of the compression.

On the adaxial surface of the coalified tissue, the venation was represented by indistinct positive relief, but was much more clearly defined on the impression of that surface. A midvein was traceable to at most the lower half on the compression, but was shorter on the impression. Punctae were not recognizable on the compression, but the impressions showed intercostal punctae, and very faint punctae on the midvein that appeared smaller than those visible on the corresponding compressions.

Abaxial coalified surfaces showed the venation in strong positive relief, including a flexuous stout midvein that is traceable to $\mathrm{ca} 80 \%$ of the pinnule length. Thereafter, the midvein branched into subsidiary veins. In the Stubbart Seam specimens, the abaxial surface of the compression showed (in positive relief) individual strands of the lateral veins connecting adjacent areolae, and pseudoanastomotic connections (see Zodrow \& Vasey 1986, figs 9A and 9D, respectively). The impressions of the abaxial coalified surface, as expected, only showed faint negative-reticulate relief that included the midvein. Punctae are recognizable on the abaxial coalified surface.

In general, topographies on the sample compressions from the Stubbart Seam ( $8 \mu \mathrm{m}$ quartz) are much more clearly defined in higher negative relief, compared with the adaxial sample impressions from the Lloyd Cove Seam $(80 \mu \mathrm{m}$ quartz). This is in part a function of grain size of the entombing sediments (the finer the sediments, the better the topographical detail). It also is probably a consequence of the adaxial surface of the pinnule in life 
Table 3. Comparison of ovules associated with Linopteris Presl. Measurements in mm.

\begin{tabular}{|c|c|c|c|c|c|c|c|}
\hline & Width & Width flange & Total width & Length & Shape & In between ribs & Surface texture \\
\hline \multicolumn{8}{|c|}{ Sydney, Nova Scotia, Canada } \\
\hline \multicolumn{8}{|c|}{ Hexagonocarpus Renault associated with Linopteris obliqua } \\
\hline & $10-13$ & 2 & $12-15$ & $17-20$ & ovoid ecuminate & $1-2$, only $1 / 2$ ovular length & Micro-reticulation \\
\hline 05-Lst\#10 & 14 & $1 ?$ & $15 ?$ & 24 & ovoid & Maybe? & Not known \\
\hline \multicolumn{8}{|l|}{ France } \\
\hline \multicolumn{8}{|c|}{ Hexagonocarpus inaequalis } \\
\hline & 13 & ? & $13 ?$ & $21-22$ & almond & Yes, not pronounced & Reticulate \\
\hline \multicolumn{8}{|c|}{ Hexapterospermum boulayi associated with Linopteris sub-brongniartii } \\
\hline & $8-10$ & $?$ & $8-10 ?$ & $14-17$ & elongate acuminate & 1 , not pronounced & Reticulate \\
\hline
\end{tabular}

showing the venation less clearly than the abaxial surface, and this is reflected in what is preserved in the corresponding impressions. From this we conclude that the venation is most unbiasedly preserved on the abaxial surface of the pinnule.

\section{Effect on iron-carbonate nodules}

Laveine (1989) reported what was then the only known occurrence of $L$. obliqua pinnules preserved together on the same slab in both siderite and in shale. The pinnules preserved in siderite were found to be ca $30 \%$ larger than the juxtaposed shale-preserved pinnules. Laveine suggested that this might be due to a differential rate of lithification (diagenesis) in the shale and siderite specimens. Because the pinnule preserved in shale had been subjected to a relatively slow process of compaction and dehydration during diagenesis, it would have shrunk. Siderite, on the other hand, precipitated much more quickly and thus preserved the pinnule before any significant shrinkage had occurred. Laveine also tentatively suggested that the siderite may have expanded slightly after precipitation, but he clearly favoured the hypothesis that the bulk of the difference in pinnule-sizes was due to shrinkage in the specimens preserved in shale.

A second occurrence of siderite-preserved L. obliqua is reported here (Fig. 24). The pinnule is "ballooned" out in size and resembles squat $L$. obliqua pinnules illustrated by Zeiller (1886, pl. 1, figs 1, 2). The reticulation pattern is distorted, but the midvein is not and shows striae and punctae that in the shale-preserved pinnules are only faintly visible and open to misinterpretation as being sedimentological in origin. This suggests that the pinnule had been caused to swell, particularly affecting the more delicate tissue where the reticulate veining occurs, but less so the more robust midvein. This swelling must have occurred after the precipitation of the siderite had occurred, but prior to the organic tissue of the pinnule becoming completely coalified.

Recent experimental work by Cleal \& Shute (paper in review) has shown that dehydration can cause shrinkage by up to $10 \%$ in Palaeozoic cuticles. Combined with the observation reported in the present paper, we can concur with the general conclusions of Laveine (1989): the difference in sizes of the pinnules preserved in shale and in siderite is partly due to shrinkage in shale and partly due to expansion in siderite (crystallization pressure). However, the evidence suggests that the bulk of the difference is due to the expansion of the siderite, and not due to the shrinkage in shale as suggested by Laveine, although this needs to be verified by a better understanding of the paragenetic relationships in the system of siderite genesis (see Krauskopf 1979, pp. 68, 69).

\section{The types of Linopteris obliqua}

Following Zodrow \& McCandlish (1978), we assume that our new foliar specimens belong to L. obliqua, the types of which originated from the Sydney Coalfield (Bunbury 1847). To try to verify this assumption, we have examined these types, which have not been described in detail before, nor have they been photographically documented.

When the senior author (ELZ) originally examined the three syntypes of this species, they were kept at the School of Botany, University of Cambridge, but they have subsequently been transferred to the Sedgwick Museum at the same University. The specimens are numbered 186, 187 and 188. Associated manuscript records show that they were collected by Richard Brown, Sr. (see also Brown 1850, p. 115), who in the 1850s was General Manager of the General Mining Association of London (GMAL). During that time, GMAL mined coal near Sydney Mines in Cape Breton, Nova Scotia (Zodrow et al. 2001, p. 68). Brown (1850, p. 126) reported that the most exploited seam then was the "Main Seam", which Bell (1938) correlated with the Harbour Seam. If so, then the syntypes are middle Asturian ('Westphalian D') in age (Zodrow \& Cleal 1985).

Specimens 186 and 187 are compressions of single pinnules, whereas 188 has impressions of several 


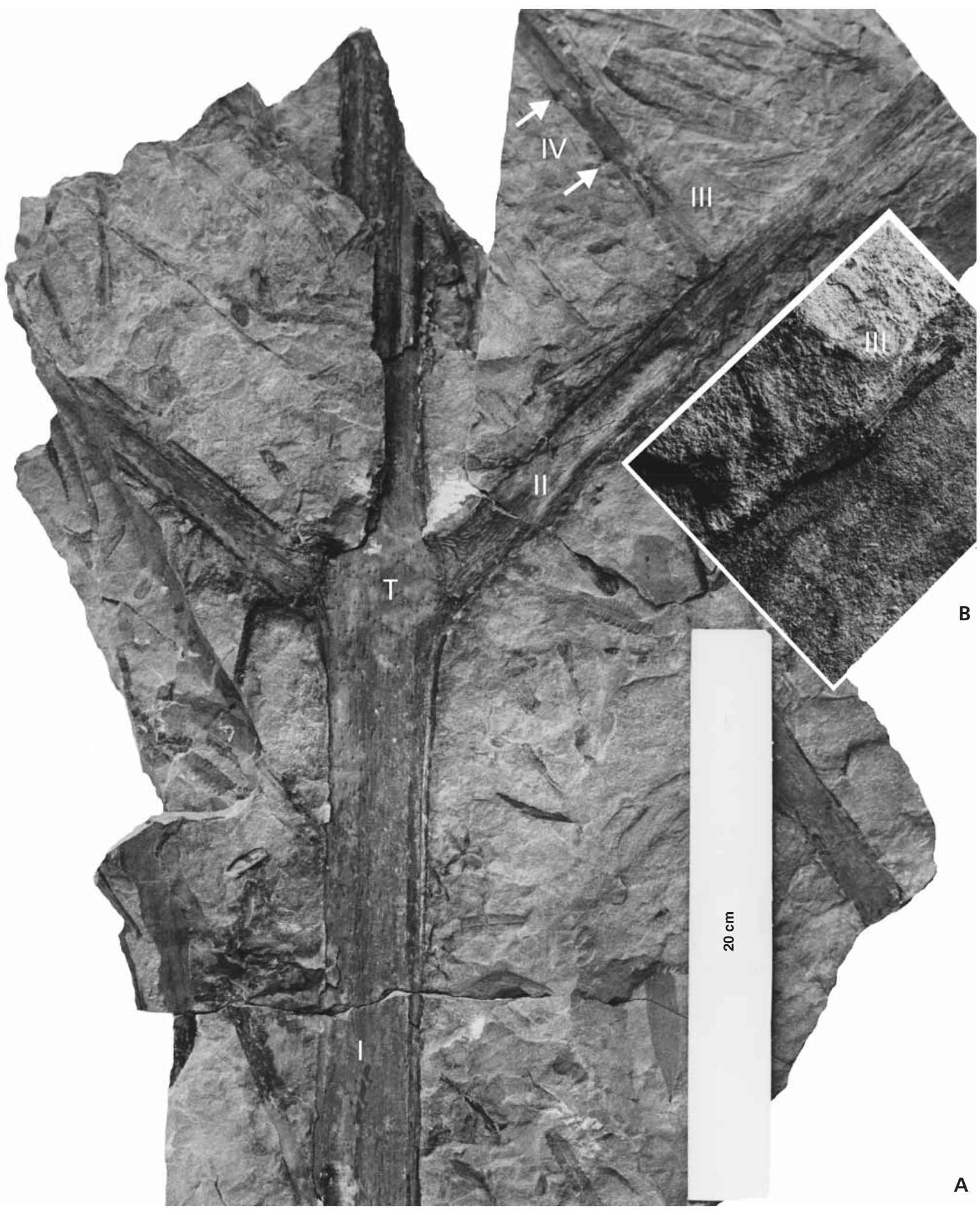

Figure 12. A - detail of axis (from Fig. 11), specimen 04-Z22b, properly prepared to expose the trifurcation at "T". Roman numerals "I to IV" correspond with the rachial order, where "I" is the referenced petiole. Arrows at "IV" point to bases, presumably pinnule-bearing. $\bullet$ Inset B $(\times 3)$ shows the area of organic attachment of axis "III" to axis "II", based on the thin coal band representing compressed axis "II". 


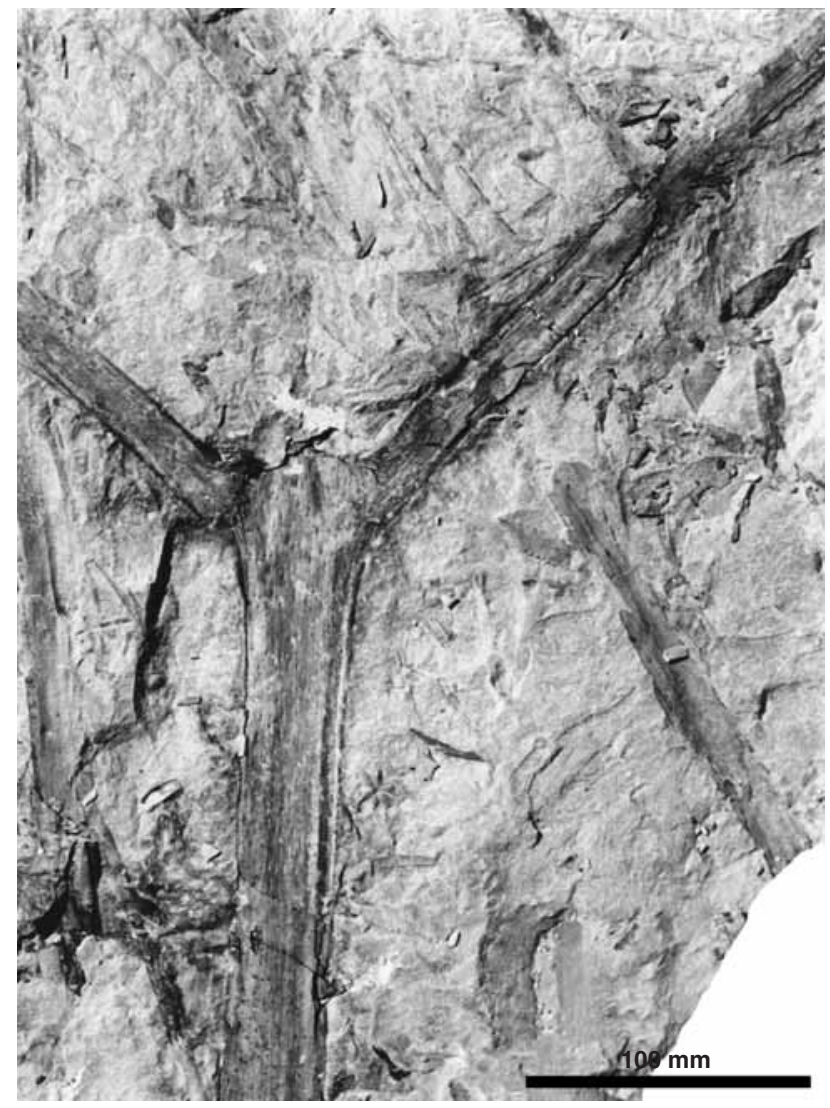

Figure 13. Field photograph, specimen 04-Z22a, Lloyd Cove Seam, Sydney Coalfield, Cape Breton, Nova Scotia; part of the pseudodichotomous axis preserved on a $c a 1 \mathrm{~m}$ by $0.60 \mathrm{~m} \times 0.40 \mathrm{~m}$ thick silty shale slab. See detail of pseudocounter part Fig. 11 and the carefully prepared trifurcate axis in Fig. 12

pinnules. The specimens are still in good condition because of the absence of destructive pyritic oxidation (Zodrow 2005). However, the coalified layer of 186 has deteriorated slightly because of localized clayey or sideritic oxidation (Zodrow 1983) in the rock matrix (the obverse is pristine). The specimens also include associated Macroneuropteris scheuchzeri (Hoffmann) Cleal et al., Lobatopteris vestita auct. non Lesquereux, lycophyte foliage, and orbicular pinnules reminiscent of odontopterids of a type often found in the Sydney Coalfield (Zodrow 1985, text-fig. 16a).

Bunbury (1847) did not designate a holotype among the specimens of this species that he had available for study. However, he figured only one of the specimens (assigned number 186) and, as this shows all the key features for identifying the species, it is designated the lectotype.

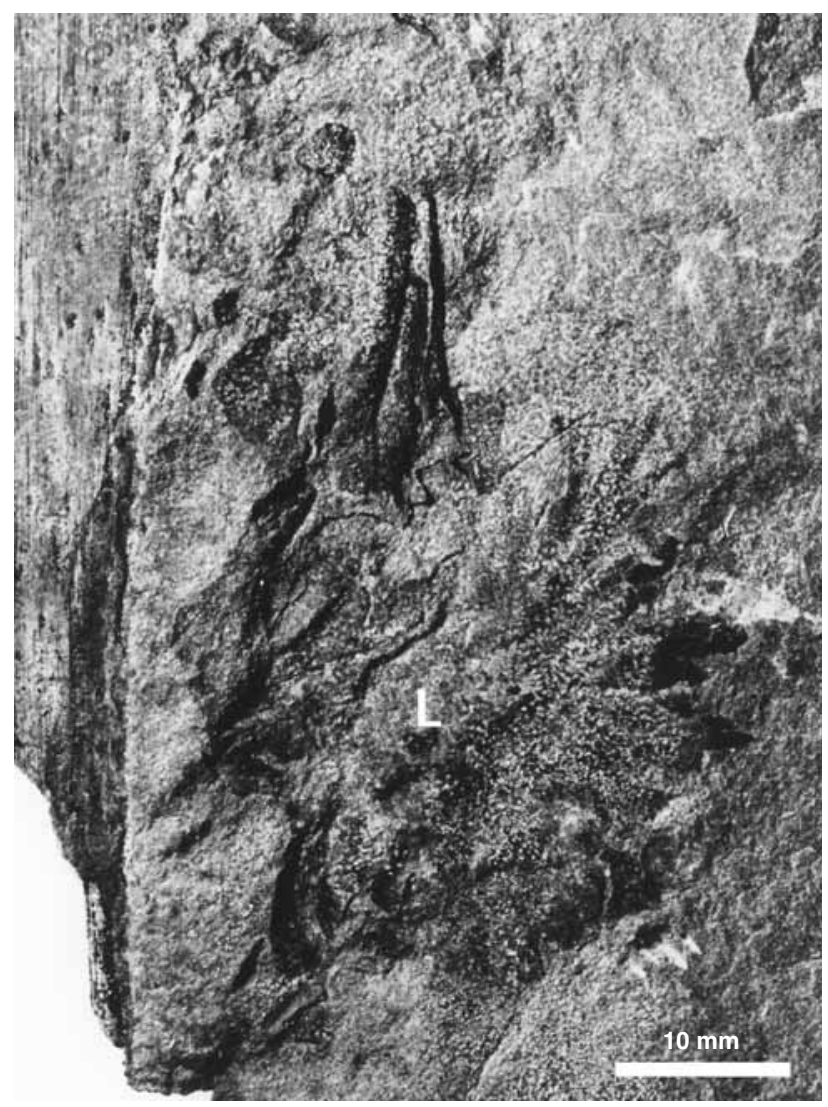

Figure 14. Petiole with possible attached laciniate structure (L), specimen 04-Z29, Lloyd Cove Seam, Sydney Coalfield, Cape Breton, Nova Scotia. From the same block as Fig. 13.

\section{Lectotype 186}

Fig. 25A shows the first published photograph of the lectotype, and Fig. 3A the first camera-lucida close-up of it, juxtaposed with a copy of the drawing published by Bunbury (1847, fig. 2B); Fig. 26 shows the pinnule outlines of all the syntypes. Lectotype 186 consists of a single pinnule that appears to be punctate, $\mathrm{ca} 16 \mathrm{~mm}$ long and $7 \mathrm{~mm}$ wide, and slightly eroded at the apex. The pinnule is laterally asymmetric, reflected both in the venation and the presence of an auricle only on the right-hand side.

The right-hand (concave) side of the pinnule has been slightly distorted. Consequently, the venation on this side looks different from that on the left-hand side: areolae on the right-hand side tend to be curved and somewhat twisted (including the hats), the midvein is locally curved (Fig. 3B at 'a'), the lateral veins appear thicker and diffused, and the micron-sized connecting-veins are

Figure 15. Basal sub-trifurcation of a linopterid petiole, specimen 05-Lst-\#11, Lloyd Cove Seam, Sydney Coalfield, Cape Breton, Nova Scotia. -A - $1.7 \mathrm{~m}$ long, naked petiole. Field photograph at oblique angle. Chisel is $302 \mathrm{~mm}$ long. $\bullet \mathrm{B}-$ shows a detail of the basal sub-trifurcation, X. Association with cauline structure is shown in Fig. 20. 


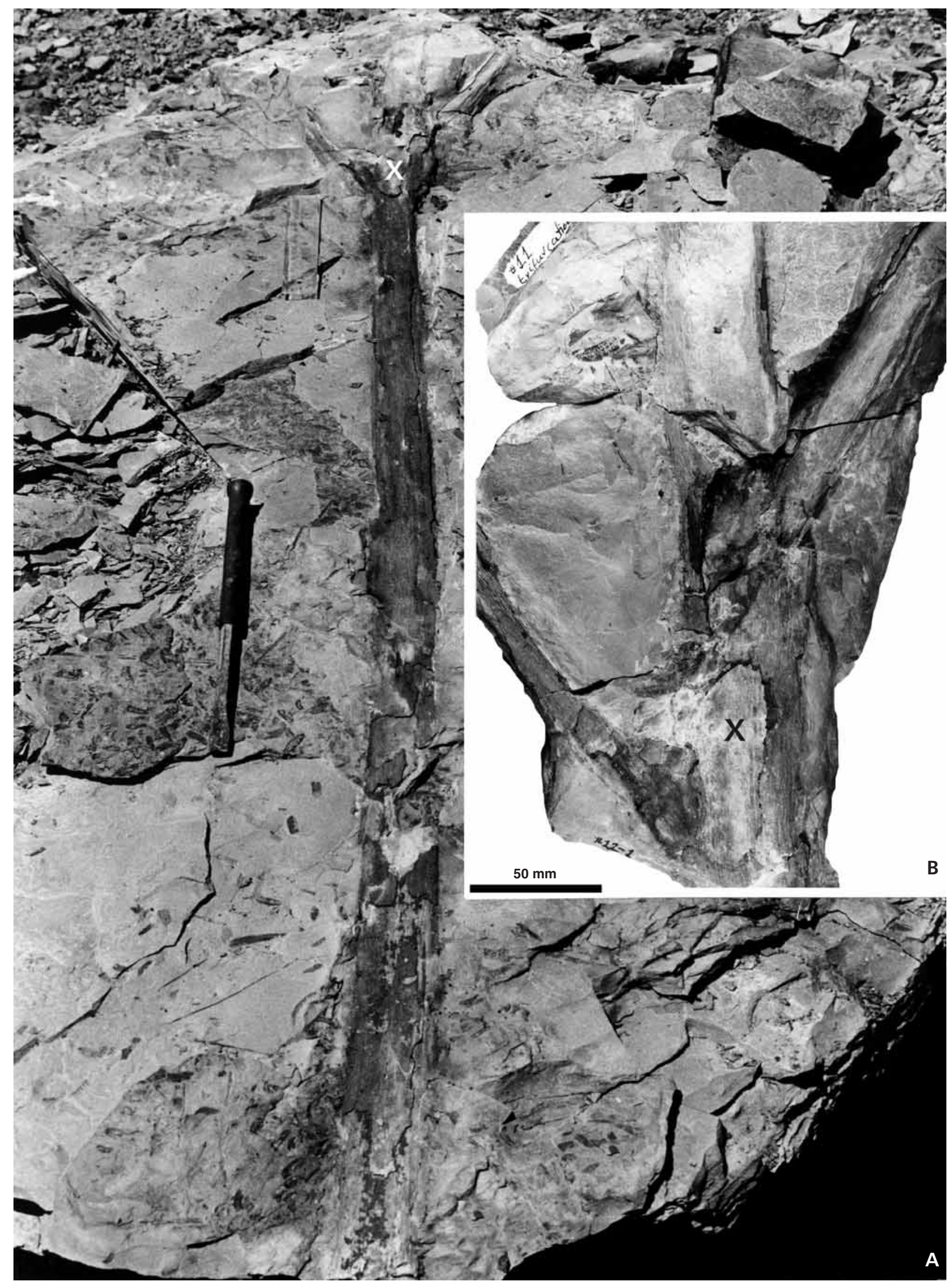


very difficult to observe. This, together with the curled margin of the pinnule, and the fact that the fossil shows the adaxial surface of the compression, probably accounts for some of the inaccuracies drawn in Bunbury's fig. 2B. This includes the erroneous number and size of the areolae in areas between the midvein and the pinnule-margin that have been drawn too isodiametrically, and the pinnule shown too wide, particularly on the lower right-hand side. However, the length of the midvein is accurately represented, as are the batteries of areolae adjacent to the left side of the midvein (compare Fig. 3A, B: a-c). Bunbury correctly showed no openended ('neuropteroid') areolae, except at the pinnule margin, but failed to note the distinctly elongate open ends of the marginal areolae.

Correctly observed by Bunbury were double-hatted areolae, where those adjacent to the midvein are aligned parallel with the midvein, and branching at the midvein that started in the lower part of the pinnule. He recognized the very short vein connectives between certain areolae (Fig. 3B, arrowed).

The camera lucida drawing, Fig. 3A, shows the flexuous midvein, probably caused by micro-distortion, defined for $80 \%$ of the pinnule length. Four to five oppositely arranged branches emerge from the midvein and proceed somewhat parallel to it, arching to reach the margin very obliquely. Areolae proximal to the midvein in the lower two-thirds of the pinnule show slender, thinning basal tails. In more distal positions, the areolae change to being six-sided, having mostly curvilinear-parallel sides, and are terminated on top and bottom by hats. Occasionally, septangular areolae are present (Fig. 3A arrows). When undistorted, the angle of the hat is $30^{\circ}$ to $45^{\circ}$, seldom much below the lower value. The more proximal areolae on the left-hand pinnule side form the most regularly-elongate hexagonal outline, with sides that are comparatively straight and near-parallel. Then, approaching the margin, the areolae become pentagonal, tetragonal or even trigonal, the frequency of micron-sized crossover vein connections increases as a result of shorter bifurcations (see Fig. 27B), and at the margin areolae are consistently, elongate open-ended. Vein density per $10 \mathrm{~mm}$ /pinnule margin is ca 45. The number of areolae on the concave side, 8 or 9 (see Fig. 3A: line c to the margin), is approximately equal to the number of successive areolae along the veins (line-of areolae). Areola "1" (as in Fig. 2) is $2.5 \mathrm{~mm}$ long and areola "9" is $0.3 \mathrm{~mm}$ wide (Table 1). Thereafter areolae decrease in size towards the margin (as factually depicted in Bunbury's fig. 2B).

The pinnule is laterally asymmetric: the size, geometry and often the number of areolae are different on either side of the midvein (usually fewer on the convex-side); and there is an auricle on the right-hand side, not mirrored on the left-hand side. The lines-of-areolae (Fig. 26A) cannot be used for the asymmetry-argument because of bias due to micro-distortion.

\section{Paratypes 187 and 188}

These specimens are also illustrated here for the first time. Specimen 187 (Figs 25B, 26B) shows the abaxial surface of a compression, $22 \mathrm{~mm}$ long and $5 \mathrm{~mm}$ wide, with possible punctae within the areolae. The number of areolae is 7 or 8 , and areolate dimensions are $1.6 \mathrm{~mm}$ length and $0.3 \mathrm{~mm}$ width, decreasing in size towards the margin. The obliquity of the line-of-areole is slight.

The small slab 188 preserves several pinnules as adaxial impressions. The longest three pinnules (incomplete length $23 \mathrm{~mm}$, width $6 \mathrm{~mm}$ ) were originally part of a fragmentary ultimate pinna, but the pinnule-bases and the ultimate rachis have been removed by erosion. The number of areolae is 8 or 9 , and areolate dimensions are $1.9 \mathrm{~mm}$ length and $0.3 \mathrm{~mm}$ width. An intact pinnule on the 188 slab, preserved as an adaxial impression (Figs 25C, 26C), is $13 \mathrm{~mm}$ long and $6 \mathrm{~mm}$ wide. Because of its smaller size, it is only slightly falcate, and the lines-of-areola are nearly straight, as normally occurs in the smaller pinnules. The number of areolae does not exceed five, and areolate dimensions are $1.2 \mathrm{~mm}$ length and $0.2 \mathrm{~mm}$ width. Fig. 28 shows the areolate architecture at the midvein of Bunbury's three Cape Breton specimens.

\section{Comparison with new specimens}

The overall form and venation of the pinnules in the specimen figured in Fig. 7, as well as in the other specimens discussed, are very similar to those seen in the lectotype 186 (although not as it was originally illustrated in Bunbury 1847 , fig. 2B) (Table 1 ). This includes pinnule size, average dimensions of the areolae, similar curvature of the lines-of- areolae, identical architecture of the areolae at the midvein, and within limits of counting bias due to curved pinnule margins identical number of areolae. Bunbury's single-pinnule lectotype could have originated from a position proximal to an antepenultimate rachis in this larger specimen. Of the total number of pinnules therein ( $c a \mathrm{n}=$ 130: Fig. 7 ), 7 to 10 pinnules ( $c a 5 \%$ to $7 \%$ ) compare morphologically with the lectotype. In contrast, in larger accumulation of L. obliqua pinnules, forms larger than $17 \mathrm{~mm}$ are not abundant. For example, in a $100 \mathrm{~mm}^{2}$ area on a $c a$ $600 \mathrm{~mm}^{2}$ silty shale slab from the Lloyd Cove Seam, of the 100 detached L. obliqua pinnules counted over $90 \%$ were of the lectotype form, and did not exceeded $17 \mathrm{~mm}$ in length. It is clear that in the Sydney Coalfield sample bias exists in collections. 


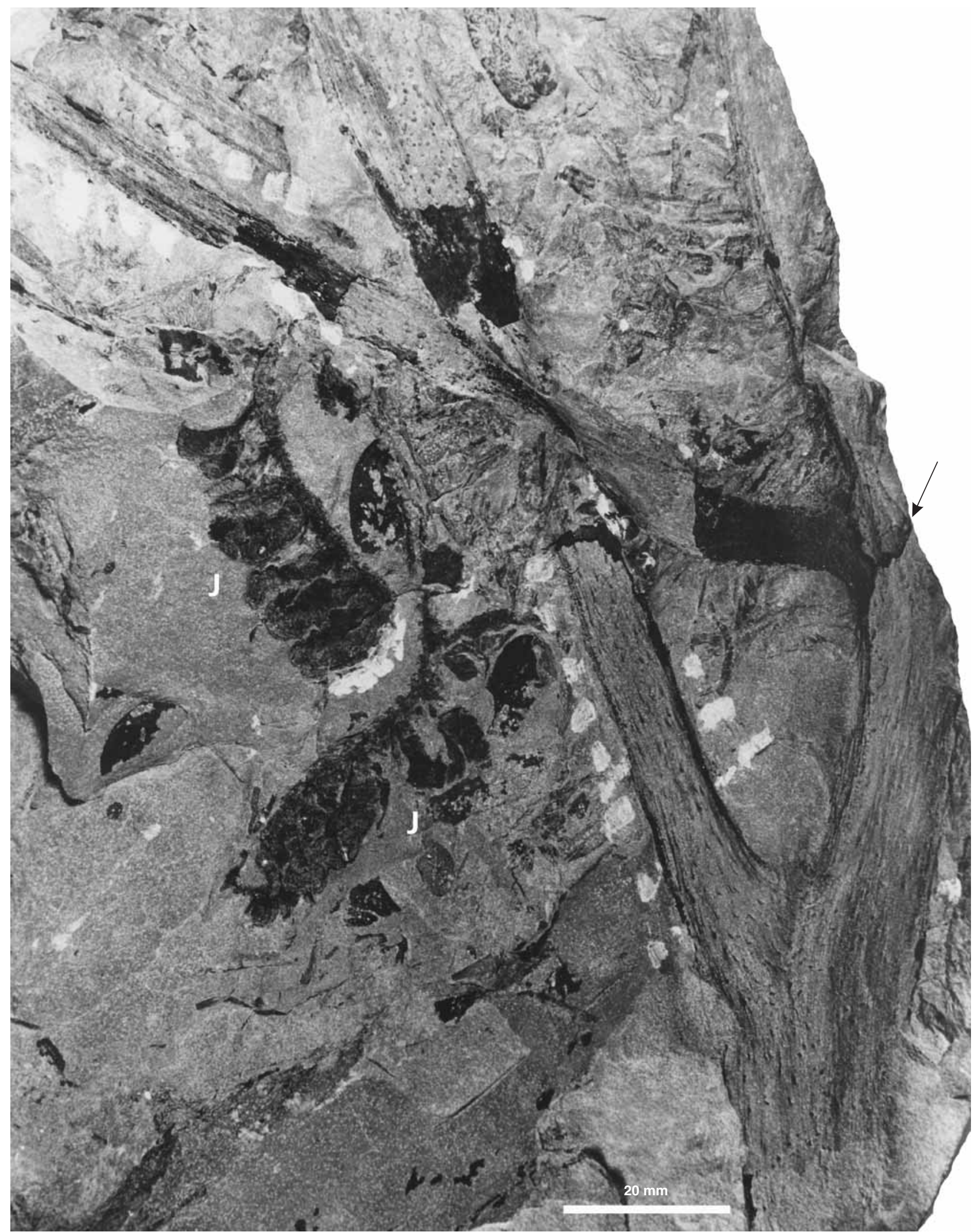

Figure 16. Juvenile frond segment of Linopteris obliqua (Bunbury) emend., specimen 04-GW-1; two attached unfurling linopterid pinnae (“J”). Lloyd Cove Seam, Sydney Coalfield, Sydney Coalfield, Cape Breton, Nova Scotia. Arrow points to a possible branching rachis. 


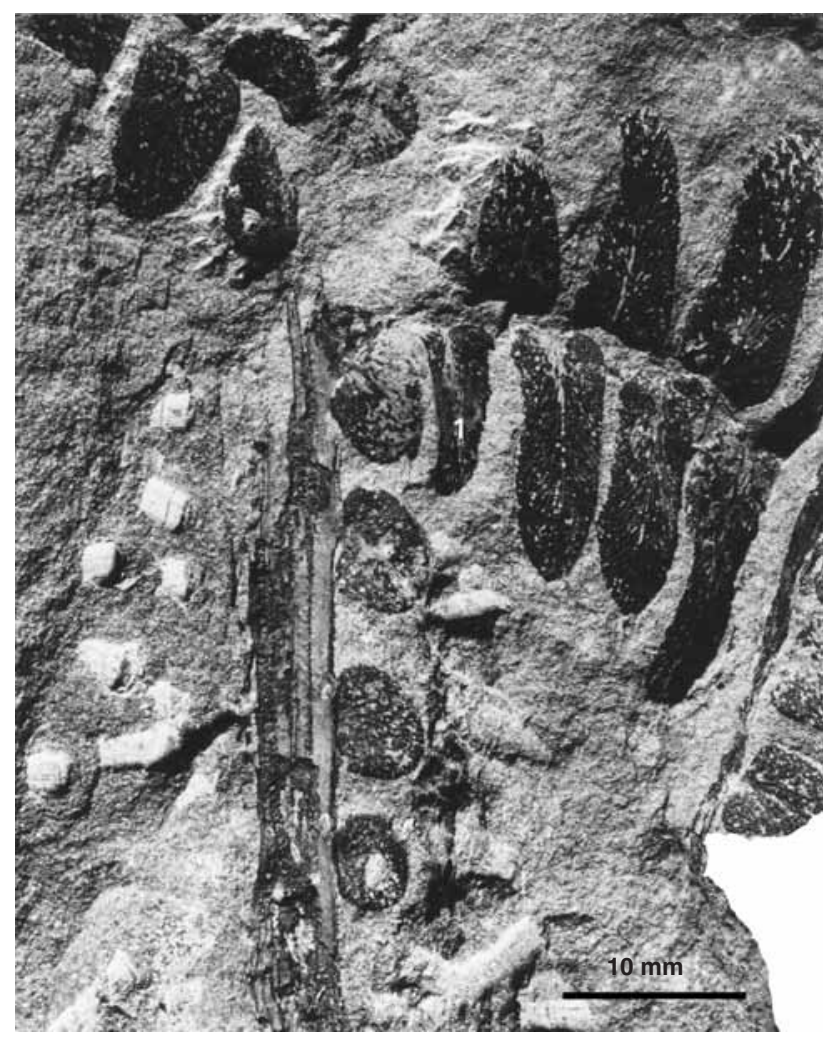

Figure 17. Linopteris obliqua (Bunbury) emend., specimen 04-Z19, Lloyd Cove Seam, Sydney Coalfield, Cape Breton, Nova Scotia; detail of a series of four intercalated pinnules exhibiting transitional morphology from linguaeform opposite ("1") to following round pinnules in decreasing size. Expected intercalated pinnules on the left-hand side of the penultimate rachis are not preserved.

\section{Morphological interpretation}

\section{Pinnule-growth pattern}

A scattergram of pinnule length/width measurements (Fig. 29) suggests an empirical growth curve with length somewhat dependent on width. This is in marked contrast to other medullosalean neuropteroids, where lateral and apical growths are correlated (Zodrow \& Cleal 1998, text-fig. 21B). This is further justification, therefore, for Gothan's (1941) separation of the paripterid/linopterid complex from the other, imparipinnate neuropteroids.

\section{Pinnule abscission}

Bell (1938) and Zodrow \& McCandlish (1978) have noted previously that massive accumulations of isolated L. obliqua pinnules occur repeatedly in the Sydney Coalfield, in the range of L. obliqua from the Harbour to Lloyd Cove Seams (Zodrow \& McCandlish 1978). Such a pattern may be interpreted as a type of event stratigraphy sensu Seilacher (1982), which almost certainly reflects periodic mass-pinnule abscission.

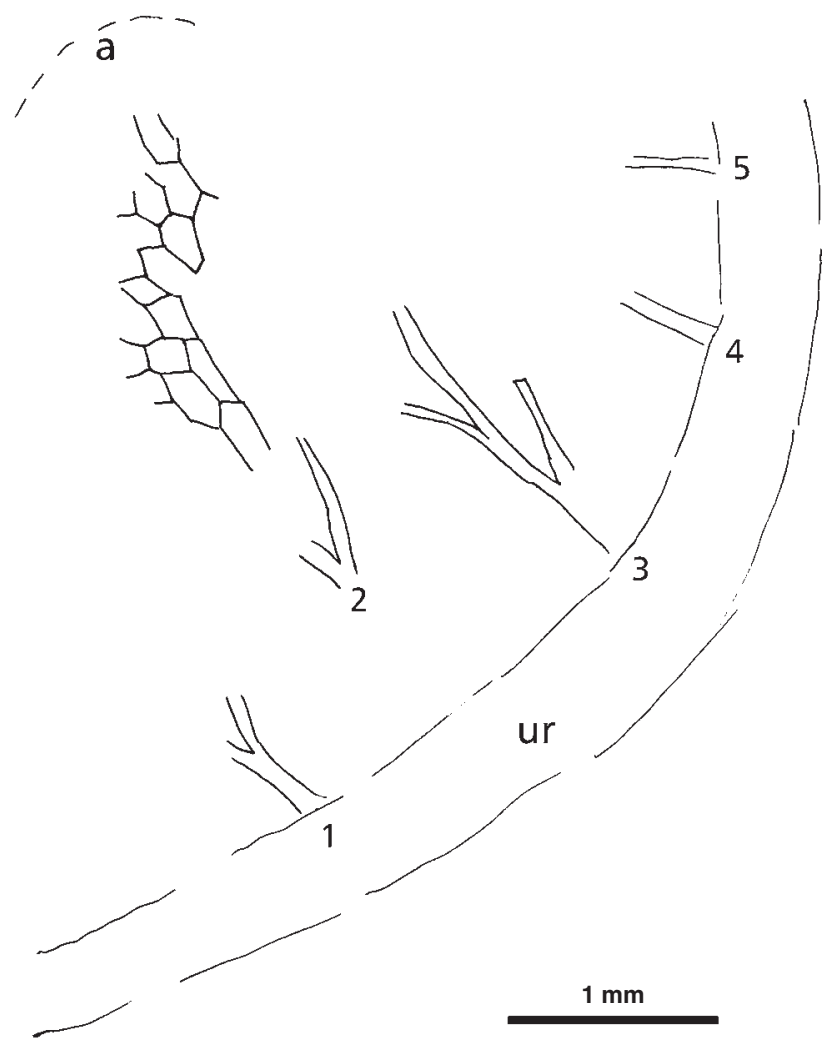

Figure 18. Linopteris obliqua (Bunbury) emend., specimen 04GW-1, Lloyd Cove Seam, Sydney Coalfield, Cape Breton, Nova Scotia; detail of the juvenile pinnules (midvein base "1 to 5") attached to the rachis "ur", except that at "2" the base connection is eroded; "a" the approximate pinnule apex. Areolae are partly preserved in pinnule with midvein "2". Camera-lucida hand drawing.

Various factors can cause leaf abscission in tropical plants, including leaf-senescence, fruiting, and ecological stress (e.g., Addicott 1982). In the case of the abscised linopterid pinnules, it is possible that it was a response to external ecological stress. Linopterid (and paripterid) pinnules had relatively thin cuticles (e.g., Barthel 1962) which may have made them more vulnerable to environmental stress. It has been suggested that these coastal Variscan Foreland plains were subjected to monsoonal climatic changes (Gibling \& Bird 1994), and in modern-day tropical plants relatively small-scale ecological changes can result in sudden leaf fall (Richards 1952).

However, in this case we are not dealing with the shedding of entire leaves, which is rarely seen in any of the known Pennsylvanian-aged tropical plants (the only well-documented example is Eremopteris - Delevoryas \& Taylor 1969). Rather, we are dealing with the mass shedding of the photosynthetic pinnules, presumably leaving the rachial "skeleton" of the leaf intact. Pinnules could presumably grow back later, suggesting that the defoliation process was a temporary and possibly a periodic process. An explanation may lie in the co-association of the pinnules with the larger numbers of ovules. In several mod- 


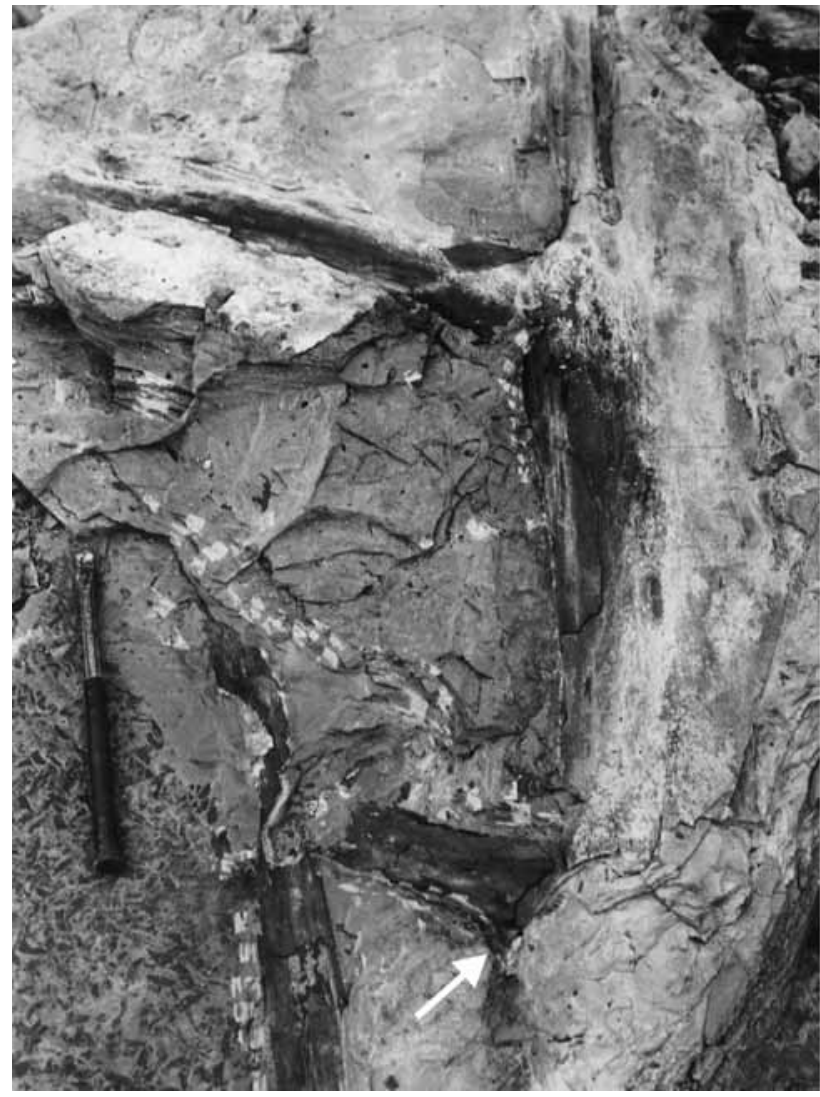

Figure 19. Linopterid trunk, branching, specimen 05-Lst\#2. Lloyd Cove Seam, Sydney Coalfield, Nova Scotia; field photograph prior to any preparatory work. Minimum width of the trunk is $21 \mathrm{~cm}$. Arrow points to connected ovulate-like structure (see Fig. 21). The chisel is $302 \mathrm{~mm}$ long and lies on one of the four biodepositional bedding planes comprised of pinnules of L. obliqua which is a few $\mathrm{cm}$ below the bedding plane that contains the trunk.

ern-day tropical plants, it has been shown that leaf fall is correlated with fruit production, as the trees temporarily divert resources away from vegetative growth to reproduction (e.g., Singh \& Kushwara 2006). The seeds of the linopterid plant were of substantial size and to produce them in the numbers that we have seen at Brogan's pit would have represented a significant resource-investment for the plant. It would seem reasonable, therefore, for the linopterid plant briefly to shed its photosynthetic pinnules to concentrate on seed-production.

\section{Frond architecture}

The present data suggest a frond at least $7 \mathrm{~m}$ long. We arrived at our estimate by interpreting the 1.7 -m long axis in Fig. 15 as being petiolate because of the tapering width that compares with that of the axes found attached to the cauline specimen (Fig. 19), and lack of attached rachises or laminate structures along its entire length. If correct, this would indicate a minimal length for a petiole. Moreover,

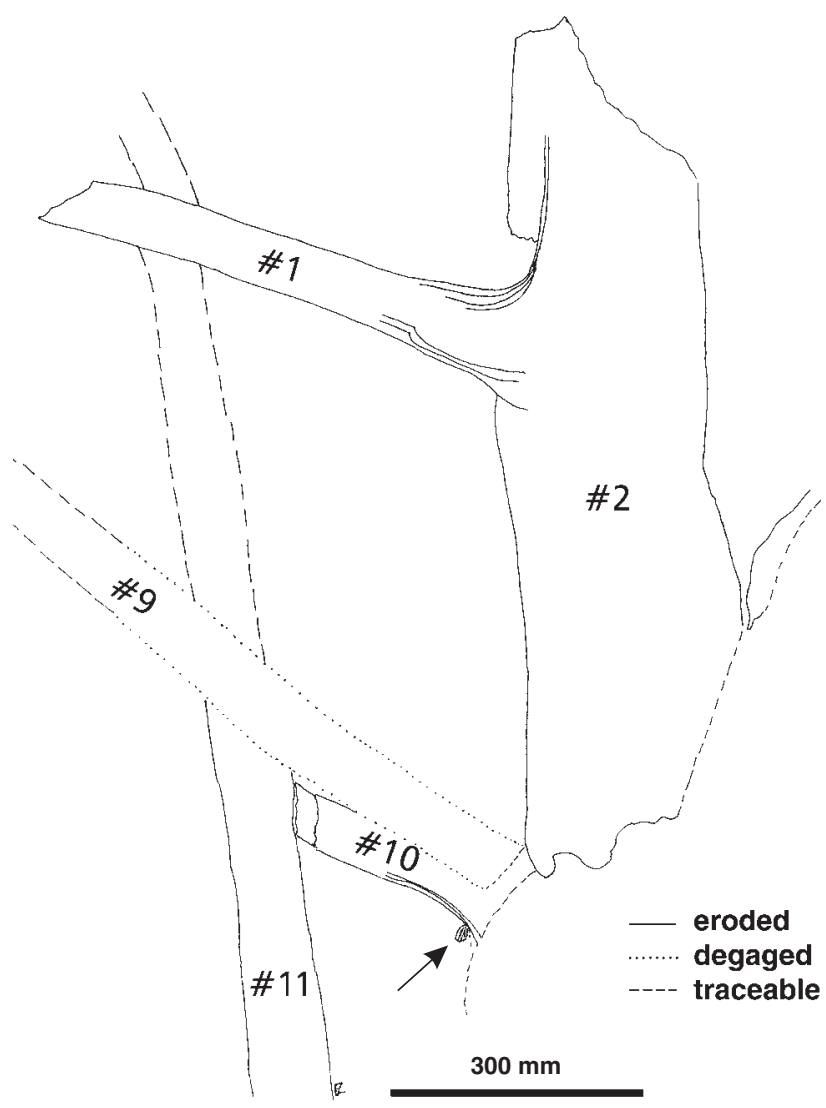

Figure 20. Cauline and rachial structures on slab 05-Lst\#0, Lloyd Cove Seam, Sydney Coalfield, Cape Breton, Nova Scotia; see Fig. 19. Succession of fossil structures uncovered (top to bottom): trunk \#2 (05-Lst\#2) with petioles \#1, \#9, \#10, and \#11, although separation is measured only in several $\mathrm{mm}$ of sediments. Documented and hand drawn in the field, assisted by photographs.

the axis in Fig. 12 only shows one trifurcation that occurs along an 0.80-m length of a primary rachis. Wnuk \& Pfefferkorn (1984, fig. 14) indicated that the fully-developed linopterid frond produced four to five pairs of secondary pinnae along the primary rachis, and estimated the full length of the frond at $c a 3.5 \mathrm{~m}$ (in agreement with Stidd et al. 1975). We regard this as too conservative, and our estimate of 7-m is more compatible with the frond as reconstructed by Laveine et al. (1993, text-fig. 11) which is $6 \mathrm{~m}$ long and $3 \mathrm{~m}$ wide.

Our evidence appears to corroborate the 'pseudo-pinnate' model for the Linopteris frond as developed by Laveine et al. (1993; see also Laveine 1997). In this model, the frond is not produced through the progressive differentiation of pinnules into pinnae, as occurs in many ferns, but is the result of a series of rachial bifurcations. As a consequence, all rachises within the frond are essentially homologous and bear pinnules. Also as a consequence, there are no pinnatifid pinnules within the frond, representing the transition from ultimate pinnules to pinna. Both points can be seen in our material. 


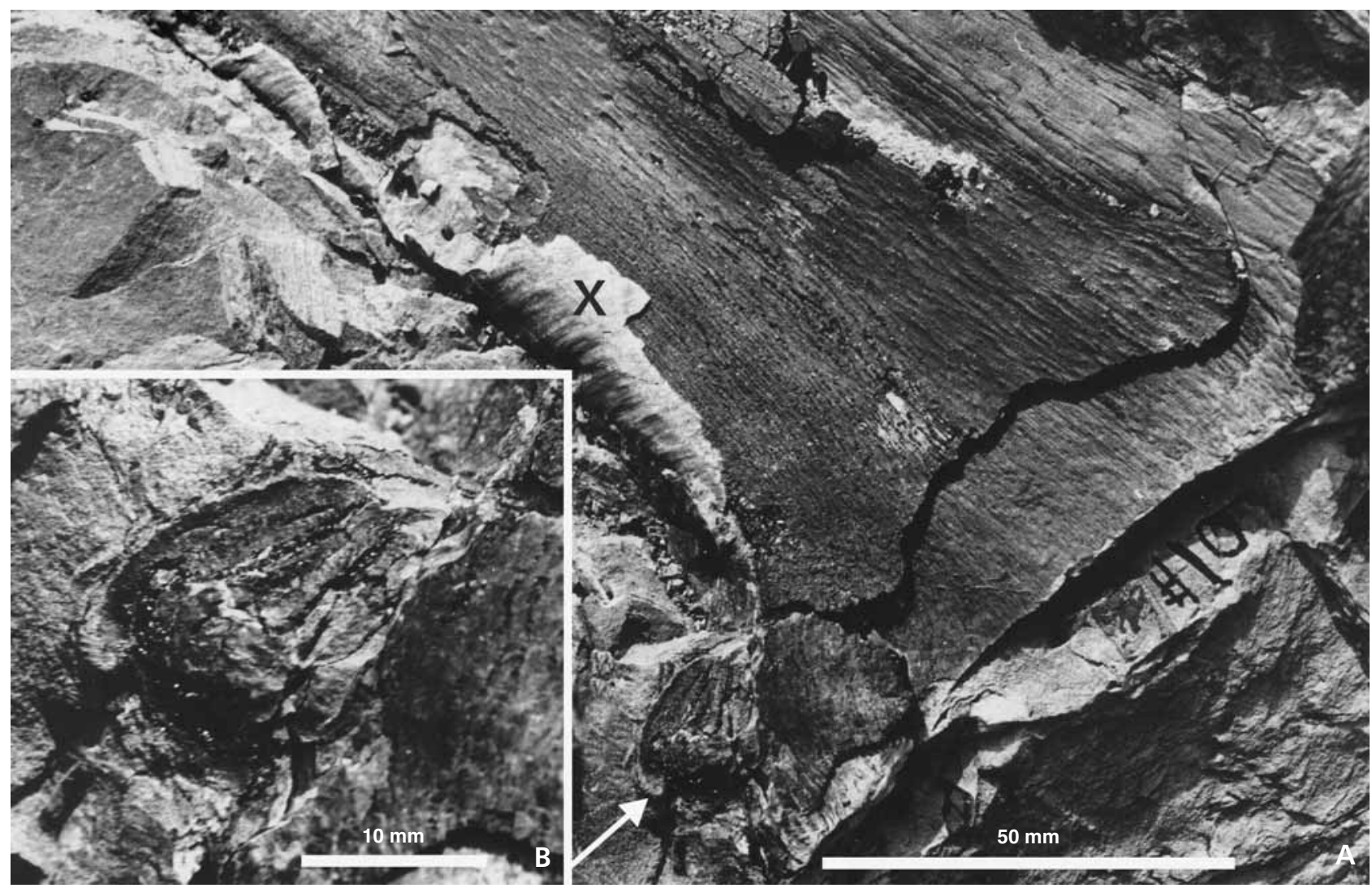

Figure 21. Hexagonocarpus Renault. Lloyd Cove Seam, Sydney Coalfield, Cape Breton, Nova Scotia. • A - arrow points to the ovule at the lower petiole-trunk juncture (05-Lst \#10-05-Lst\#2, respectively). Field photograph. X, crater splash in muddy sediment, is regarded stratigraphically the bottom of the shale slab. $\bullet \mathrm{B}$ - enlargement of the ovular structure, noting that the distal part appears the broadest.

We also have evidence to support the view of Laveine et al. (1993) that secondary rachises are alternately arranged in the distal part of the frond, but may converge to being apparently oppositely arranged in the proximal part of the frond (Figs 10B, 11-13). However, where this apparently opposite arrangement is found, the resulting trifurcation is often not in a single plane, giving this part of the frond a certain degree of three-dimensionality. Other evidence of three-dimensionality within the frond is shown in Fig. 7, where ultimate pinnae are fanned-out, and the laterally overlapping ultimate pinnae are significantly separated from each other by a layer of sediments.

In our view, therefore, the Linopteris frond is not a strictly planar structure as suggested by Laveine et al. (1993) and Wnuk \& Pfefferkorn (1984), but shows some evidence of three-dimensionality within its architecture. This is not surprising if we accept the pseudo-pinnate model for the Linopteris frond architecture. Although the repeating bifurcations by which the Linopteris frond was built-up occurred primarily in one plane to produce a mainly dorsi-ventral photosynthetic structure, they were presumably derived from three-dimensional branching systems, such as suggested in Zimmermann's Telome Theory (Zimmermann 1952). What we are seeing in Linopteris is the retention of some of this primitive three-dimensionality within the frond, notably in those parts where the repeated bifurcations have become telescoped to produce 'pseudo-opposite' branches and thus have imposed some constraints of space for the branching.

\section{Juvenile foliage}

We interpret the specimen shown on Fig. 16: J as representing part of a young quadrpinnate foliar segment. The only alternative explanation would be that the main axis was part of a stem, and that this bore tripinnate fronds. We find this untenable for three reasons. Firstly, our evidence suggests that the fully-developed fronds of this plant were quadripinnate which is borne out by previous reconstructions of the fronds of Potoniaceae (e.g., Laveine et al. 1993). Secondly, the subsidiary axes appear to be laterally attached to the main axis, rather than helically attached as would be expected if the latter were a stem. Thirdly, the main axis is substantially narrower than the example of the 0.21-m thick stem that we document in Fig. 19.

The general architecture and ontogeny of this juvenile frond appears to be similar to that documented for Pari- 
pteris Gothan by Cleal \& Laveine (1988). However, in the absence of attached secondary rachises on the right-hand side of the linopterid specimen, the exact rachial architecture cannot unequivocally be determined. The two preserved secondary pinnae on the left-hand side of the main pinna appear to be very closely spaced, which may indicate an incompletely developed frond. Alternatively, it is possible that the more distal of the two secondary rachises was originally attached to the right-hand side of the main rachis, and that it had been twisted around during burial; it should be noted that the more distal secondary rachis shows clear evidence of twisting along its length. In this case, however, it would suggest that the secondary pinnae were alternately attached, whereas most other evidence suggests that they were oppositely attached, producing the apparently trifurcating branches discussed previously.

\section{Epidermal hairs}

The punctae that occur on the pinnules and all orders of rachises in L. obliqua have traditionally been interpreted as hair bases. Although hair-covered abaxial, and sometimes adaxial pinnule surfaces, are well-documented in the Medullosales (e.g., Barthel 1962, Cleal \& Zodrow 1989, Zodrow \& Cleal 1998), if the L. obliqua punctae are correctly interpreted as hair bases their density would be exceptional among the Medullosales; in life, the foliar surface would have resembled a clothes brush. Such a densely hairy surface would have been an ideal defence against attacks by insects, or even foraging tetrapods. It has to be noted, though, that no actual hairs were recovered from macerations of $L$. obliqua pinnules in this or other studies, and it could be argued that the holes observed in its cuticles (e.g., Fig. 30B) represent hydathode pores. As discussed by Shute \& Cleal (2002), hydathodes can have a multitude of forms and structures, and some can be difficult to distinguish from hair bases. However, in this case, the holes are surrounded by a far more prominent collar of cuticle than normally occurs in hydathodes and, on balance, we suspect that they represent hair bases.

\section{Reproductive structures}

Ovules preserved as adpressions similar to those found at Brogan's pit have traditionally been known as Hexagonocarpus Renault. Carpentier (1911) reported similar ovules associated with Linopteris subbrongniartii Grand'Eury (see also Laveine 1967a). However, for the first time we report an ovule in probable direct attachment to a linopterid plant. Documented examples of organically-attached medullosalean ovules are extremely rare (summarized by Zodrow 2007), the present discovery being only the second known case from the Sydney Coalfield (see Zodrow \& McCandlish 1980).

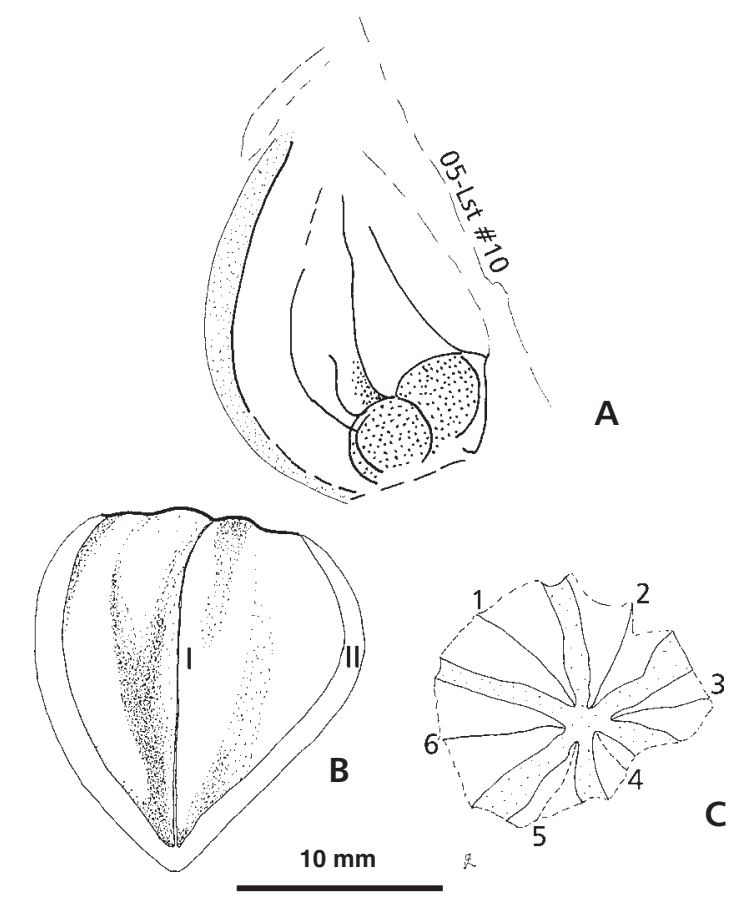

Figure 22. Hexagonocarpus Renault, Lloyd Cove Seam, Sydney Coalfield, Cape Breton, Nova Scotia. - A - axillary-associated ovule (see Fig. 21), specimen 05-Lst\#10. Peripheral flange-like structure (stippled). Camera-lucida hand drawing. • B - detached ovule 980-540 showing ribs (shaded), commissure (I), and flange-like structure (II). $\bullet \mathrm{C}-$ partial mold showing hexagonal symmetry (stippled ribs) intersected by what is interpreted as commissures, numbered " 1 to 6 ", where dashed lines indicate some erosion. Based on the specimen figured in Fig. 23B.

In comparison with Carpentier's (1911) material (Table 3), the Sydney ovules tend to be a little longer and more pyriform in shape, but Carpentier's material appears differently preserved by consistently showing three narrow longitudinal ribs (sclerotesta?). The distal end of the attached Sydney ovule (Fig. 22A) has a similar configuration and shape to Carpentier's (1911, Pl. VI, fig. 1) "face inférieure", although the latter author did not mention the positive relief. Also noticeable on some of Carpentier's material is a flange-like structure surrounding the ovules, similar to that observed in the present material (see Figs 22A, B, 23A).

The position of attachment of the Sydney ovule to the proximal part of a frond-petiole (Fig. 21) is unique among the medullosaleans; the few other known examples of attached medullosalean ovules have them connected to the distal parts of the fronds (e.g., Buisine 1961), or to branching axes whose position relative to the rest of the plant is unknown (Drinnan \& Crane 1994).

Medullosalean seeds are generally uncommon in the compression fossil record, and we know of no other published record of abundant ovules being associated with abundant vegetative remains of mainly one species. We speculate, therefore, that we are seeing here a reproductive biology characterized by brief periods of seed production.

In contrast to the abundance of the ovules, the extreme 
Table 4. Summary of morphological characteristics of selected linopterid types. Measurements in mm. Data from Tenchov et al. (2005), except that for L. obliqua (Bunbury) emend.

\begin{tabular}{|c|c|c|c|c|c|c|c|c|}
\hline \multirow{2}{*}{\multicolumn{2}{|c|}{ Form species and synonyms }} & \multicolumn{4}{|c|}{ Pinnule morphology } & \multicolumn{3}{|c|}{ Areolae } \\
\hline & & \multirow{2}{*}{$\begin{array}{c}\text { Length } \\
16\end{array}$} & \multirow{2}{*}{$\begin{array}{c}\text { Width } \\
7\end{array}$} & \multirow{2}{*}{$\begin{array}{c}\text { Margin } \\
\text { curviparallel }\end{array}$} & \multirow{2}{*}{$\begin{array}{l}\text { Shape } \\
\text { falcate }\end{array}$} & \multirow{2}{*}{$\begin{array}{c}\text { Number } \\
6-7\end{array}$} & \multirow{2}{*}{$\begin{array}{c}\text { Length/width } \\
2.0 / 0.5\end{array}$} & \multirow{2}{*}{$\begin{array}{r}\text { Shape } \\
\text { hexagonal }\end{array}$} \\
\hline (1) & L. obliqua (Bunbury) Zeiller & & & & & & & \\
\hline$(1 \mathrm{~A})$ & L. bunburi Bell & $10-11$ & $3-5$ & curviparallel & elongateovate & $4-5$ & $? ?$ & open hexagonal \\
\hline (2) & L. neuropteroides (Gutbier) Potonie & $30-35$ & $12-13$ & curviparallel & falcate & $8-12$ & $10.0 / 0.3$ & sharp elongate \\
\hline$(2 \mathrm{~A})$ & L. palentina Wagner & \multicolumn{7}{|c|}{ subjective synonym of $L$. neuropteroides } \\
\hline$(2 \mathrm{~B})$ & L. gangamopteroides de Stefani & \multicolumn{7}{|c|}{ part of the L. neuropteroides group } \\
\hline (3) & $\begin{array}{l}\text { L. neuropteroides var. minor (Potonie) } \\
\text { Bertrand }\end{array}$ & 22 & 6 & parallel & linear/falcate & $6-7$ & $5.0 / 0.25$ & hexagonal \\
\hline$(3 \mathrm{~A})$ & L. neuropteroides var. latenervosa Teixeira & \multicolumn{7}{|c|}{ synonym of L. neuropteroides var. minor } \\
\hline (3B) & L. minor var. linearis Wagner & \multicolumn{7}{|c|}{ subjective synonym of L. neuropteroides var. minor } \\
\hline$(3 \mathrm{C})$ & L. duplex Němejc & \multicolumn{7}{|c|}{ synonym of L. neuropteroides var. minor } \\
\hline (4) & L. brongniartii (Gutbier) Zeiller & $15-25$ & 12 & parallel & linear/falcate & $8 ?$ & $3.5 / 0.5$ & hexagonal \\
\hline (5) & $\begin{array}{l}\text { L. subbrongniartii (Grand'Eury) sensu } \\
\text { Zeiller }\end{array}$ & 25 & $9-12$ & $\begin{array}{l}\text { parallel } \\
\text { slightly } \\
\text { convex }\end{array}$ & falcate & $10-14$ & $6.0 / 0.4$ & subrhomboidal \\
\hline (6) & ?L. semianastomosa Tenchov & 27 & 8 & semiparallel & linguaeform & $4-5$ & $2.0 / 0.3$ & rhombic \\
\hline (7) & L. elongata Zeiller & $30-35$ & $7-8$ & parallel & elongate & $5-6$ & $6-7.0 / 0.8$ & hexagonal \\
\hline (8) & L. regniezii Laveine & $15-20$ & $5-7$ & parallel & linguaeform & $6-7$ & $3.1 / 0.5$ & rhomboid \\
\hline (9) & L. florinii Teixeira & \multicolumn{7}{|c|}{ dubious as species and based on strongly deformed pinnules } \\
\hline$(10)$ & L. weigelii (Sterzel) Daber & 70 & 25 & parallel & linguaeform & $>10$ & $9.0 / 1.0$ & $\begin{array}{l}\text { elongate } \\
\text { hexagonal }\end{array}$ \\
\hline (11) & L. havlenae Tenchov \& Popov & 30 & $7-13$ & parallel & slightly falcate & $>10$ & $8.0 / 0.3$ & elongate \\
\hline
\end{tabular}

scarcity of the Potoniea pollen-organs in Brogan's pit is noteworthy. It is the reverse situation from China, where Laveine et al. (1993) reported a great abundance of Potoniea Zeiller associated with Potonieaceae foliage, in the absence of ovules. Poor preservation is unlikely to be an explanation for the Canadian situation, as preservation is extremely fine here. It could be that the linopterid plants were dioeceous, and that the specimens found at Brogan's pit were female and those reported from China by Laveine et al. (1993) were male. However, there has been no evidence to suggest that other medullosaleans were dioeceous so this explanation is also probably unlikely. A more likely explanation is that what we are seeing are plants that produced their ovulate and pollinate structures at different times in order to avoid self-pollination, an idea which is supported by the observation that the male and female organs were preserved in different layers within the rock [compare with similar observations made by Jongmans (1952) and Retallack \& Dilcher (1988) on the reproductive biology of other Carboniferous pteridosperms].

\section{Reconstruction of the plant}

Laveine et al. (1993, text-fig. 12) reconstructed their Viséan paripterid from China as being a self-supporting plant some $12 \mathrm{~m}$ high, with a trunk just under $0.2 \mathrm{~m}$ in diameter and fronds estimated to be up to $6 \mathrm{~m}$ long. The Brogan's pit material appears to represent a plant of very similar habit, with a trunk just over $0.2 \mathrm{~m}$ in diameter in its distal part and fronds $7 \mathrm{~m}$ long. The petioles of both the Chinese and Canadian fronds have a somewhat swollen base, of a form often interpreted as indicating a climbing habit for the plant, but we agree with Laveine et al. (1993) that this is unlikely in view of the width of the trunk.

Laveine et al. (1993) suggested that the apparently slender trunk of the Linopteris-bearing tree may have been partly supported by adventitious roots, as found in other arborescent medullosaleans, but little evidence of this was found in either their study or ours. Since most examples of trunks that could be linked with Linopteris were from near the top of the tree, it is possible that the trunk may have been rather wider at ground-level, which would have given it more support. On the other hand, the trunks of a number of modern-day tree-ferns of the Cyatheaceae are of similar height and girth, and can support frond many meters long.

\section{Vein reticulation in Linopteris}

\section{Reticulation pattern as a taxonomic parameter in Linopteris Presl}

Venation is most clearly observed on the abaxial surface of linopterid pinnules, as the veins protrude from the lamina. 

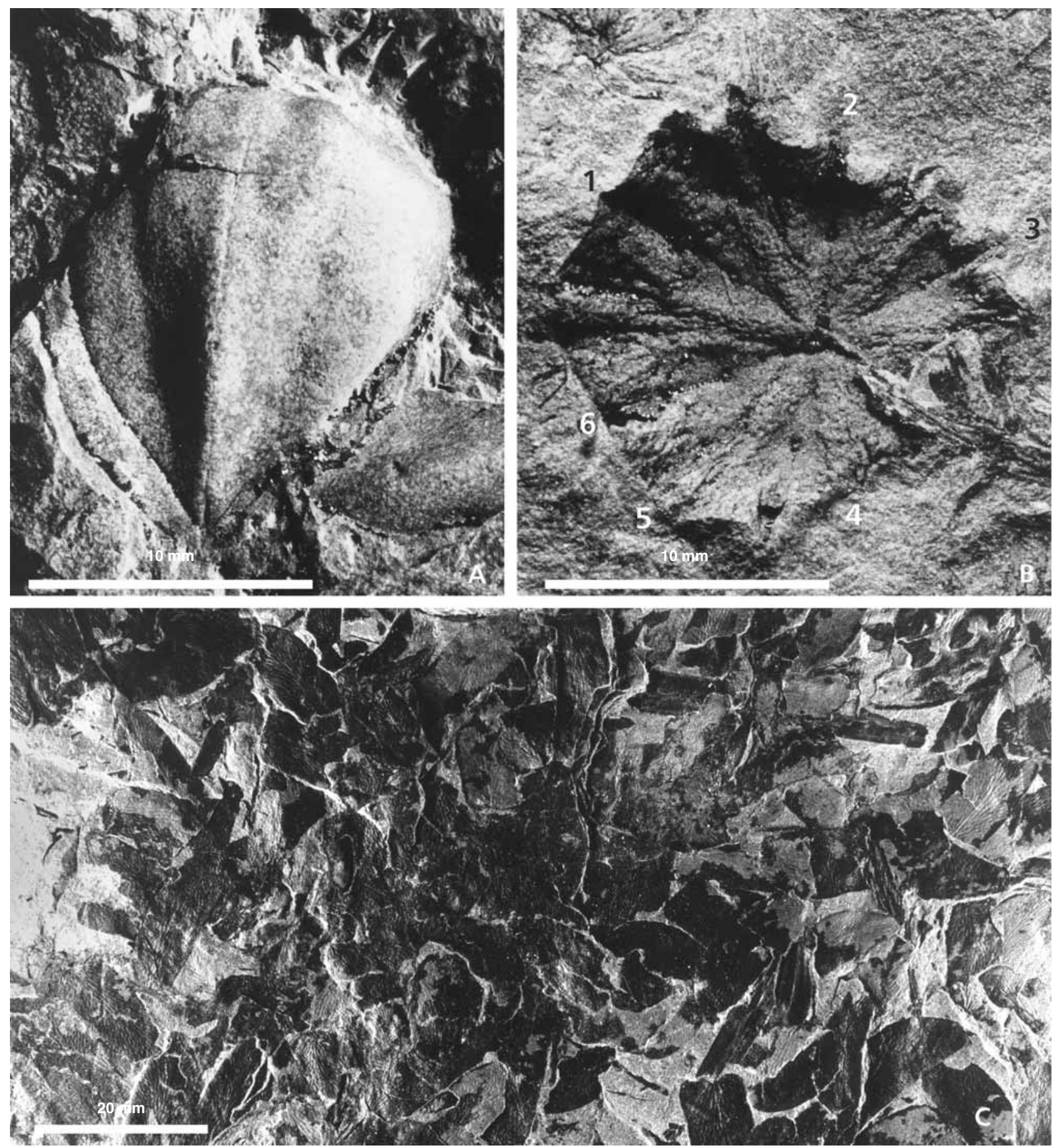

Figure 23. Lloyd Cove Seam, Sydney Coalfield, Cape Breton, Nova Scotia. • A - Hexagonocarpus Renault showing flange-like structure at the left, and broad ribs. • B - partial mold showing commissures numbered " 1 to 6", and attendant 6-fold symmetry structure emanating from the center. $\bullet \mathrm{C}-\mathrm{de}$ tail of one of the four bedding planes defined by a plethora of abscised pinnules of L. obliqua (Bunbury) emend. $1.7 \mathrm{~m} \times 1.3 \mathrm{~m}$ by $0.46 \mathrm{slabs}(05-\mathrm{Lst} \# 0$ ).

In particular, the midvein length always appears longer on the abaxial surface compared with the adaxial surface (see Figs 3A, 31 compare A to B). Any taxonomic arguments based on midvein parameters without reference to which side of the pinnule is being studied [e.g., Crookall 1959, p. 211, on the separation of L. obliqua from Linopteris neu- ropteroides (Gutbier) Potonié] can be highly misleading. Also, the tailed areolae discussed earlier can only be considered taxonomically significant if it can be shown they are not due to differential merging with a thicker lamina.

Based on a literature survey of seventeen published linopterid types and suggested synonymies (summarized in 


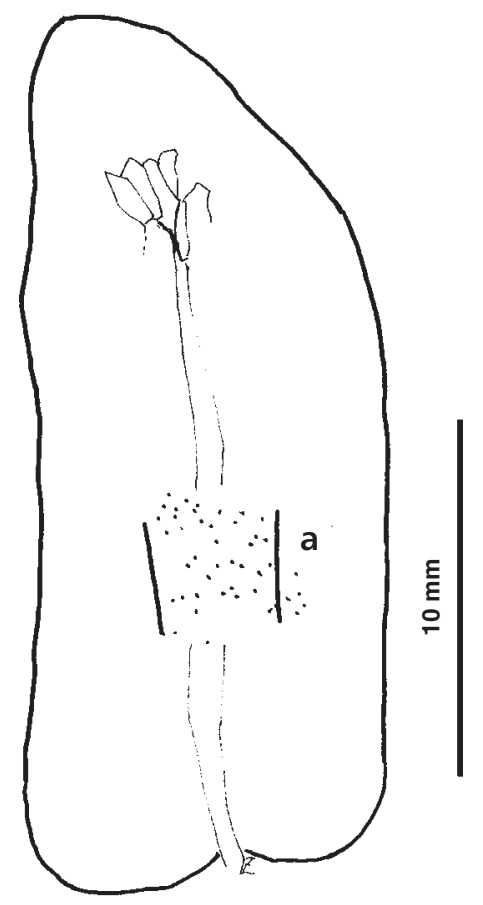

Figure 24. Linopteris obliqua (Bunbury) emend., specimen 04-Z25a, Lloyd Cove Seam, Sydney Coalfield, Cape Breton, Nova Scotia; figured is an abaxial-pinnule impression ballooned in width by siderite crystallization (concretionary genesis). Inset "a" represents a factual portion of the magnified midvein with accurately positioned punctae. Dense punctae also occur on the entire lamina.

Table 4), it is clear that there has been a tendency to rely on qualitative taxonomic parameters (e.g., pinnule and areolate shapes) that have been subjectively interpreted, and which can differ on the abaxial and adaxial surfaces of the lamina, as demonstrated in this paper. The solution clearly hinges on the ability to analyze the lateral-venation pattern that shows complex and variable reticulate patterns generally based on elongate, polygonal areolae.

We suggest that linopterid foliage can be separated based on an areolate ground plan (or typus sensu Schindewolf's 1980, p. 240) similar to Bocheński's (1960) concept of peri-rachial characters for distinguishing species of Alethopteris Sternberg and Lonchopteris Brongniart. For linopterids, the typus is extensively manifest in the areolate architecture at the midvein, and is assumed to be independent of frond position for any given Linopteris species. To illustrate this, we have chosen the typus of seven linopterid specimens, emphasized by blotting out the remaining pinnule venation for each (Fig. 32). We propose the following battery of test variables, designed to capture the geometric-dimensional attributes of the areolae near the midvein. (1) Proportion of the long-axis of the areolae that is parallel to the midvein.

(2) Length-width dimensions.

(3) Geometry of the hat.

(4) Curvature.
(5) Dimension (5a), geometric shape (5b) and curvature (5c) of areolae in the proximal part of pinnule but still in contact with the midvein.

Of these, variable (5) was already implicitly emphasized by Potonié (1904) in his description of lateral-vein development in L. neuropteroides (Gutbier) var. minor Potonié (see Fig. 27C).

A focused summary of typus attributes of seven linopterid specimens (including six types) is given in Table 5 (based on data in Fig. 32). Three form groups (A) to (C) are recognizable (A) L. obliqua-L. cf. obliqua-L. neuropteroides var. minor, (B) L. regniezii, and (C) L. neuropteroides var. major. L. brongniartii fits somewhere in between because the vein areolae are less parallel and form a rosette in the proximal part of the pinnule. L. neuropteroides (Gutbier) var. minor shown in Fig. 32F is similar to that of the larger linopterid pinnules in the Sydney Coalfield (e.g., Fig. 9). This would seem to lend some support to the general thesis of Zhang et al. (1992) and Laveine et al. (2003) that many of the presently-recognized linopterid morphospecies merely represent intraspecific variation within highly polymorphic fronds. In our view, however, their assertion that $L$. neuropteroides, L. subbrongniartii, L. obliqua and $L$. brongniartii should be interpreted as one species is taking the argument too far, at this juncture. To develop the analysis further, the type specimens themselves clearly need to be re-studied and compared directly to allow a full generic circumscription to be established, and a "a generic similarity matrix" be developed sensu Pšenička (2005); see also Darrah $(1969$, p. 83) for an analysis of the pitfalls of iconography.

Bocheński (1960, figs 1, 4) used the characteristics of vein meshes adjoining the midvein (his first-row meshes), and the vein branching-pattern in the peri-rachial (proximal) part of the pinnule, to distinguish lonchopterid species. A cursory analysis showed that, on this basis, the netted genera of Lonchopteris Brongniart, Lonchopteridium (Gothan) Guthörl emend. Zodrow \& Cleal, Linopteris Presl, and Reticulopteris Gothan are objectively separable, although they may share a common phylogeny. On the other hand, using these same criteria, it is difficult to distinguish isolated pinnules of the imparipinnate medullosalean Barthelopteris germari (Giebel) Zodrow \& Cleal (e.g., Krings \& Kerp 1998, figs 3-5) from detached pinnules of the paripterid medullosalean L. obliqua. This emphasizes the necessity of integrating frond architectural and cuticular data, coupled with statistical models (see below) to confirm form-specific linopterid determinations in a taxonomically consistent manner.

\section{Modeling vein reticulation in Linopteris}

Modeling venation pattern in Linopteris Presl may help identify more objective taxonomic parameters. Unlike other 

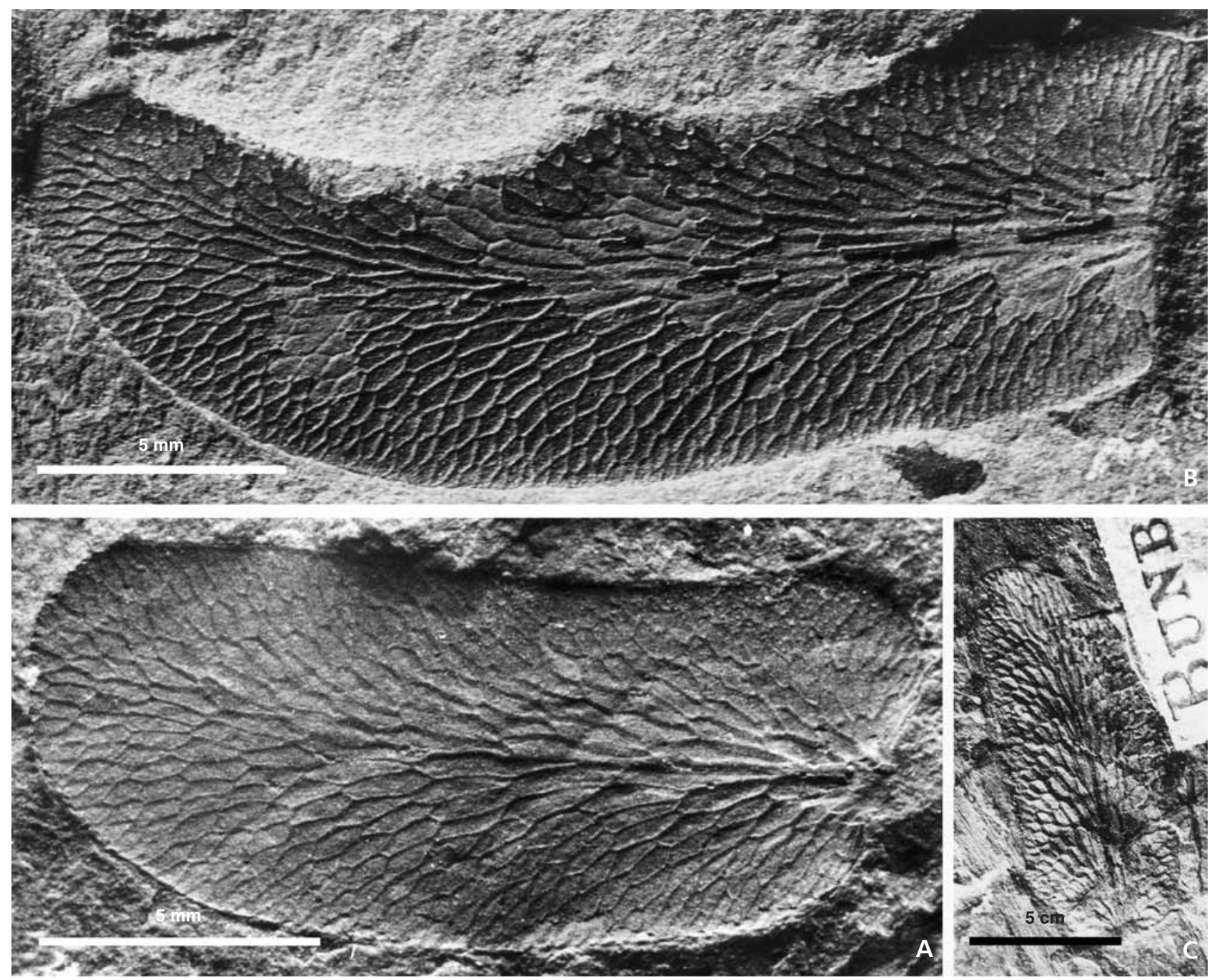

Figure 25. Bunbury's specimens, Bunbury Collection, Cambridge University. • A - Dictyopteris obliqua Bunbury; 186, Bunbury (1847, fig. 2B). Catalogued by Bunbury (1850) as Dictyopteris Gutbier, D. Brongniarti var. minor. Sydney, Cape Breton. Richard Brown, Esq. • B-C - paratypes, 187 and 188, are not figured in Bunbury (1847), but catalogued by him in 1850 as Dictyopteris Gutbier, D. Brongniarti var. minor respectively. Sydney, Cape Breton. Richard Brown, Esq. "Open-ended" areolae seen in the photographs are due to incident-light beam. In fact, they are interconnected to form closed networks.

pteridospermous groups with a one-dimensional (linear) venation pattern, Linopteris Presl venation is of two-dimensional geometry and thus ready-made for mathematical treatment. Two mathematical models merit consideration (Krumbein \& Graybill 1965). One is a deterministic model to account for the observation that areolae are most elongate near the midvein, becoming shorter thereafter in the direction of the pinnule margin. We have followed Bocheński's (1960) notation in naming rows, choosing one of the main branching systems in the lower (proximal) part of the pinnule as a starting point (Fig. 33). Let the midvein be designated the zero (0) areola, the adjacent areola 1 , and continuing outward along a lateral branching system (e.g., Fig. 27B), a series is realized 0, 1, 2, 3, 5, 8, 9 (Fig. 33) which on first approximation resembles the Fibonocci Series $0,1,1,2,3,5,8,13$ (see Smith 1958). The differences between our observed sequence and the classic Fibonocci Series can be explained by the limited laminate width and the variable pattern of bifurcations. Alternatively, the observed pattern of areolae in Fig. 33 could mathematically be simulated to reproduce the venation typus, for instance using fractal geometry (see Heggie \& Zodrow 1994 for the use of fractal geometry for modeling a Carboniferous lobatopterid-fern frond).

The second modelling approach is through probability theory: the stochastic model that assumes independent variables and random data, i.e. introduction of an uncertainty factor into the deterministic model. A highly complex model that could explain vein reticulation as a purely abstracted physical phenomenon can be represented by Markov Chains of conditional [transition] probability (Kolmogorov 1956, and references therein). 


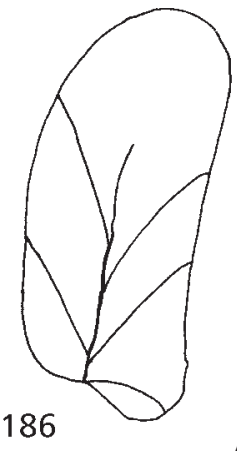

A
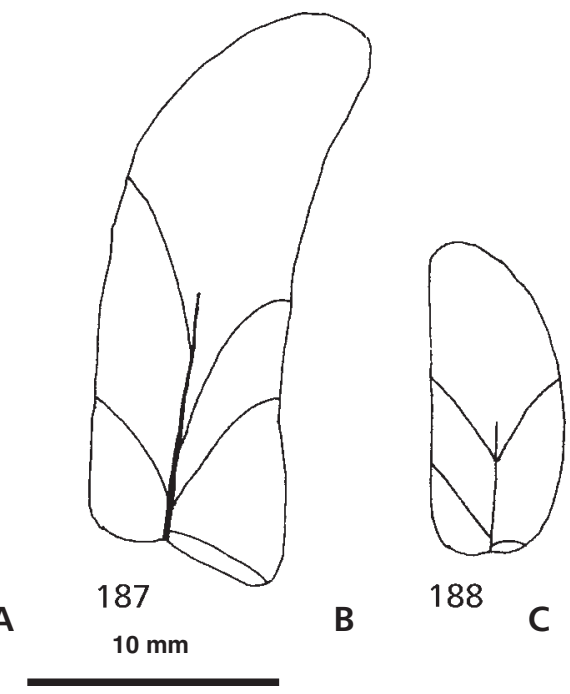

188

Figure 26. Linopteris obliqua (Bunbury) emend. Sydney Coalfield, Cape Breton, Nova Scotia; pinnule outlines with lines-of-areola in the syntypes. A - lectotype 186 . B-C - paratypes, 187 and 188 , respectively.

If explanatory interests centre on the probability-distribution phenomenon of "vein endings" (positive integers = events), i.e. premodeled by linopterid branching as in Fig. 27B, then Zodrow \& Banerjee's (1993) approach merits consideration which models the generalization of the binomial probability law to the nth degree of vein endings.

Simultaneous areolate length-width variation in the form of a two-dimensional probability surfaces (the continuous bivariate model) would à priori exclude the normal LaPlace-Gauss law because of the natural trend in areolate-length-width reduction that appears to be uniform (monotonic decreasing function) in the direction of margins. Such data derived from inherent trends have the frequency characteristic of the mode not being equal to the mean, resulting in a tailed distribution best represented by a skewed model, such as the well-understood family of exponential (lognormal) curves which on appropriate logarithmic-base transformation of variables approximates characteristics of the normal curve (Zodrow 1973).

Clearly much potential exists for statistical modelling to improve our understanding of the mathematical nature of the linopterid venation. Specifically, appealing are the concepts of the $3^{\text {rd }}$ and $4^{\text {th }}$ mathematical moments in continuous-distribution theory for being population discriminators in biometrics (Cramér 1945, p. 175). The bivariate length-width areolate model is recommended. However, a rigorous mathematical development, evaluation, and application of such techniques are beyond the scope of the present paper.

\section{Development of Potonieaceae vein-reticulation}

Reticulate venation patterns of linopterid taxa have been presented and described in the literature as depicted in
Fig. 27A, i.e. generally without reference to (1) ontogenetic development, (2) adaxial/abaxial orientation, and (3) branching pattern at the midvein (however, see Bocheński 1960 and Tenchov \& Popov 1987). In addition, the underlying assumption that reticulation is by anastomosis is based on venation characteristics determined from coalified compressions (see Bocheński 1960), and could be subject to thermal bias (organic metamorphism). Anastomosis has never been confirmed by observation in Linopteris Presl, either through cuticular analysis or coal-ball sectioning, to shed light on the nature of the lateral-vein fusion and cross-over veins, as being anastomosed.

Reticulate venation can develop in different ways [e.g., see examples found in extant ferns discussed by Wagner (1979); see also Tryon et al. (1990, p. 253, fig. 129)]. The best documented in the Medullosales is where the veins become progressively more flexuous, and adjacent veins ultimately merge by tangential anastomosis. This has been most clearly demonstrated in the Neurodontopteridaceae, with a progressive change through the Westphalian Stage of the Variscan Foreland from of the open-veined Neuropteris obliqua (Brongniart) Zeiller to the reticulate-veined Reticulopteris muensteri (Eichwald) Gothan (Josten 1962, Tenchov \& Popov 1991). Details of the tangential anastomosis of the veins have also been demonstrated in naturally macerated cuticles (Zodrow \& Vasey 1986). Bocheński (1960) argued that a similar transition could be identified in the Alethopteridaceae, but this has not been documented in such detail.

However, vein reticulation appears to have developed in a different fashion in the Potonieaceae (Tenchov \& Popov 1987). In this family, adjacent lateral veins become connected by cross-over veins (for an analogy, see Zodrow \& Vasey 1986, fig. 16A). These cross-over veins are very short, and manifest in three-sided hats that resulted also in septangular areolae (Fig. 3A, arrow, Fig. 6G), or connections between the midvein and the branches (Fig. 27B). If the cross-over veins are erased from the veining pattern in this figure, and using the main-lateral veins emitted from the midvein (recognizable by their sturdy appearance) as a guide for locating ensuing bifurcations, a zigzag lateralbranching pattern is revealed (Fig. 27B). These main-lateral veins are sub-oppositely arranged on either side of the flexuous midvein, mostly originating in the proximal part of the pinnule, and are initially relatively straight and quasi-parallel to the midvein. They extend into the apical regions of the pinnule, with only three to four of these main veins on either side of the midvein to food-supply the entire pinnule lamina (see analogous situation in Fig. 27C). The main-lateral veins bifurcate at most five times and zigzag, reaching the margin open-ended and obliquely, producing a marginal vein density of 40-45 veins per $10 \mathrm{~mm}$.

The pattern of vein reticulation in the Potonieaceae, where there is no evidence of tangential anastomosis, is 
clearly quite different from that seen in the Neurodontopteridaceae and probably the Alethopteridaceae, and is another feature that serves to separate the former from the other families within the Medullosales. Nevertheless, there is no sharp demarcation between Paripteris Gothan \& Linopteris Presl, as the former can sometimes show rare cross-over veins, the generic distinction between the openveined and reticulate-veined forms clearly being artificial (e.g., see comments by Zodrow \& Cleal 1998). For species definition, however, areolate geometry (i.e. the typus) remains an important discriminating taxonomic character.

Linear measurements suggest an estimated $10 \%$ to $20 \%$ increase in vein length is realized by reticulation, as compared with the curvilinear open venation. The observed change from Neuropteris to Reticulopteris in the Neurodontopteridaceae appears to correlate with a change to lesswet climatic conditions (Zodrow \& Cleal 1993, Cleal \& Shute 1995). The equivalent change from Paripteris Gothan to Linopteris Presl cannot so readily be interpreted, however, and reticulate veining in extant plants has been shown to result from various selection pressures that can include mechanical strength of the leaf and its response to herbivory, as well as hydraulic factors (Uhl \& Mosbrugger 1999, Roth-Nebelsick et al. 2001). At present, we have insufficient evidence to interpret these changes in the Potoniaceae.

\section{Systematics}

Although Linopteris Presl has traditionally been used as a morphogenus for foliar fossil material (e.g., Laveine 1967a), Barthel (1962) suggested that it could be re-interpreted as a natural genus for a whole plant, a view with which Laveine et al. (1993) later agreed. The evidence for interpreting Linopteris Presl as such (following the methodology of Retallack \& Dilcher 1988) appears compelling. Details of the architecture of the fronds have been worked out in some detail (Laveine 1967a, 1997; Wnuk \& Pfefferkorn 1984; Pfefferkorn et al. 1984; Laveine et al. 1993; and this study), and epidermal characteristics are known, including the type of monocyclic stomata (Barthel 1962). We now have provided evidence for an attached ovule of the type of Hexagonocarpus Renault, and there is a consistent physical association of linopterid foliage with pre-pollen organs Potoniea Zeiller (Carpentier 1911; Laveine 1967a, 1971; for summary see Laveine et al. 1993, and this study). There is even evidence that the plant was arborescent, and it is widely assumed that the stems, when anatomically-preserved, are of the Sutcliffia Scott type which bears affinity with Medullosa Cotta (see summary Laveine et al. 1989, Stidd et al. 1975), although the biological connection between them has as yet not been fully demonstrated.

Tempting therefore is a revision of the formal taxonomy of these fossil fragments as whole organisms. How-

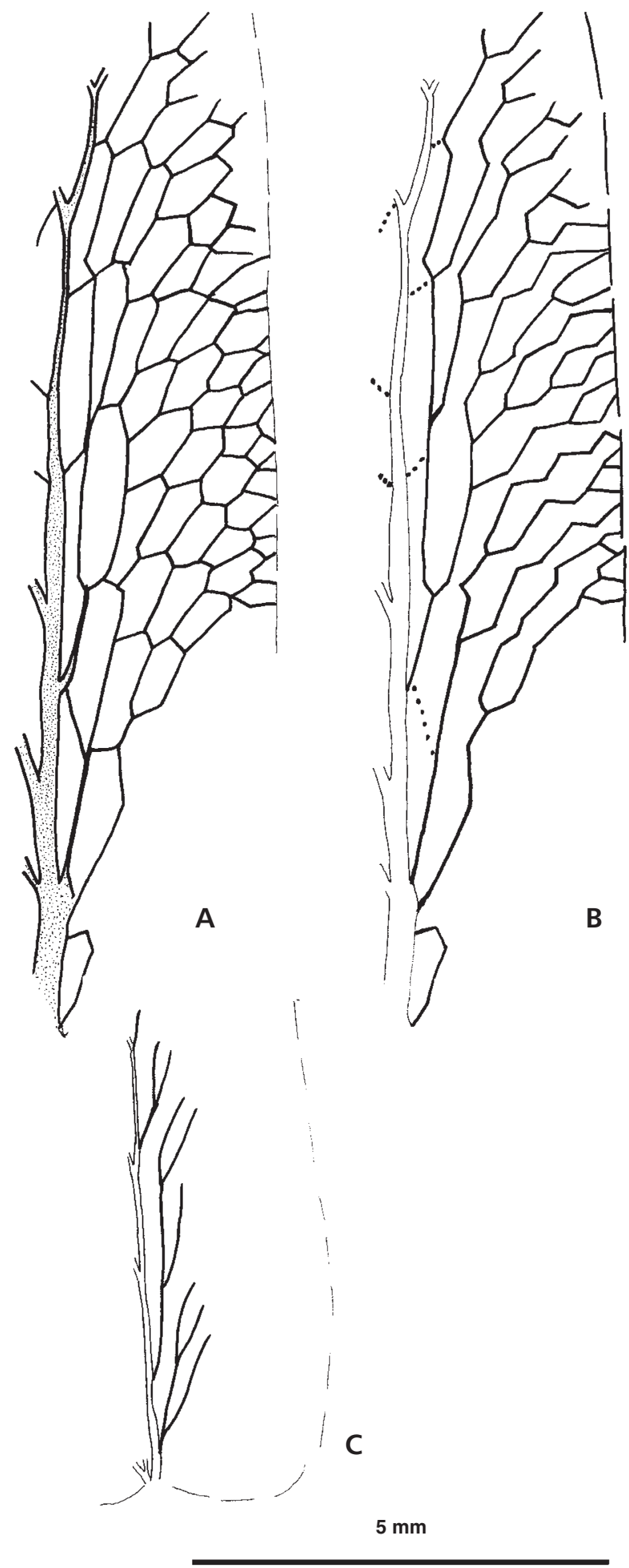

Figure 27. Modelling areolate-venation pattern in Linopteris Presl. • A-B - Linopteris obliqua (Bunbury) emend., Lloyd Cove Seam, Sydney Coalfield, Cape Breton, Nova Scotia. $\bullet$ A - following literature to depict reticulation pattern, specimen $04-\mathrm{Z} 27$. $\bullet \mathrm{B}-$ after removal of crossover connections at the midvein (...) and elsewhere of $\mathrm{A}$ to diagnose the branching pattern. $-\mathrm{C}$ - branching architecture at the midvein in Linopteris neuropteroides var. minor (Potonié 1904, Lief. II, 28) homologous to $\mathrm{B}$. 


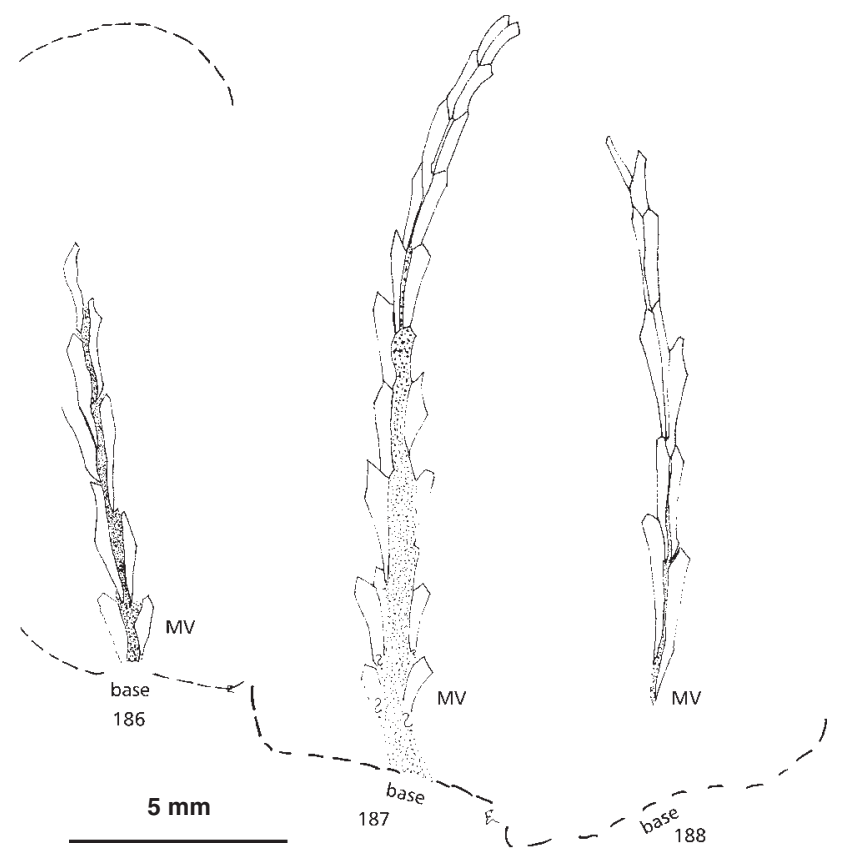

Figure 28. Linopteris obliqua (Bunbury) emend. Sydney Coalfield, Nova Scotia; areolate architecture at the midvein of the syntypes. Lectotype 186, paratypes 187 and 188. Length for 188 is incomplete. "Base" = pinnule base; MV - midvein.

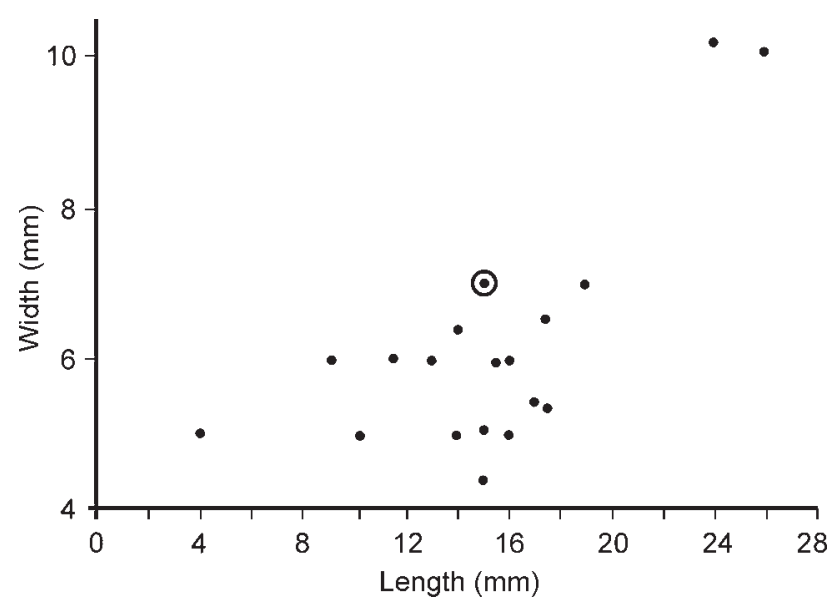

Figure 29. Scattergram, pinnule length/width of Linopteris obliqua (Bunbury) emend. (Table $1, \mathrm{n}=19$ ). The encircled point represents the lectotype 186 . Note a trend shift to the right.

ever, as soon as we look at the practicalities of doing this, nomenclatural problems arise immediately (see Chaloner 1986, for a discussion of the problems of naming whole fossil plants). We can undoubtedly have a coherent wholeplant concept to which the specific epithet obliqua can be linked. The problem arises when we consider the genus to which it should be assigned. One option might be to propose formally an emendation of the morphogenus Linopteris Presl so that its diagnosis and circumscription encompass the entire plant. However, this assumes that the type of Linopteris Presl (L. gutbieriana Presl ?L. brongniartii (Gutbier) Potonié), which is currently based purely on foliar features, can confidently be accommodated within the radius of this whole-plant concept. Also, where would this leave all of the other morphospecies currently included within Linopteris Presl but for which we have less complete evidence of the rest of the plant? Some would undoubtedly belong to the same whole-plant genus, but possibly not all. So, we would end up with the unsatisfactory situation where another morphogenus would have to be erected to accommodate morphospecies of linopterid-like foliage but which, for lack of information, cannot be included within the whole-plant genus.

Alternatively, we could opt to erect a new genus for the whole plant that bore L. obliqua foliage. There is the drawback here of introducing an additional name into the taxonomic literature, the scientific benefits of which are debatable. There is also the problem of designating the type. Although the type of a genus is often quoted as a species, in fact the International Code of Botanical Nomenclature (Greuter et al. 2000) stated that it is a specimen. Since our knowledge of these plants is based exclusively on fragments, there can be no specimen of the whole plant that could act as type. We would therefore have to choose as type a fossil that would only represent part of the plant. Although there is nothing in the Code that would invalidate such a choice, there are clearly potential difficulties in this approach.

One of them is the philosophical issue of whether formal taxonomic nomenclature should be used for something that is not real. Although the evidence for the reconstruction might be strong, in almost all circumstances the reconstructed plant will be a construct in the mind of the beholding palaeobotanist. Only if we find the fossilized remains of a complete plant will the reconstruction become a reality, and even then an incomplete one due to the loss of most soft tissues and cellular detail.

At the end of the day, we have to ask if the taxonomic benefits that would be accrued through developing such a whole plant genus outweigh the nomenclatural and philosophical problems that would result. Since we are for the most part using this nomenclature for naming the fossilized fragments of the plants, then the answer must probably be "no". Only in generalized discussions on plant ecology would a name be needed for the whole plant. To surmount, for example, a comparable problem, Crane (1984) used the informal name 'Nyssidium plant' to describe the whole angiosperm plant bearing Nyssidium fruit and Trochodendroides leaves, and we believe that a similar approach is best in the case dealt with in the present paper. So, we will continue to regard the formal taxon Linopteris obliqua (Bunbury) as a foliar morphospecies (including details of frond architecture and epidermal structure: see Diagnosis), and refer to the whole plant informally as the Linopteris obliqua plant. 

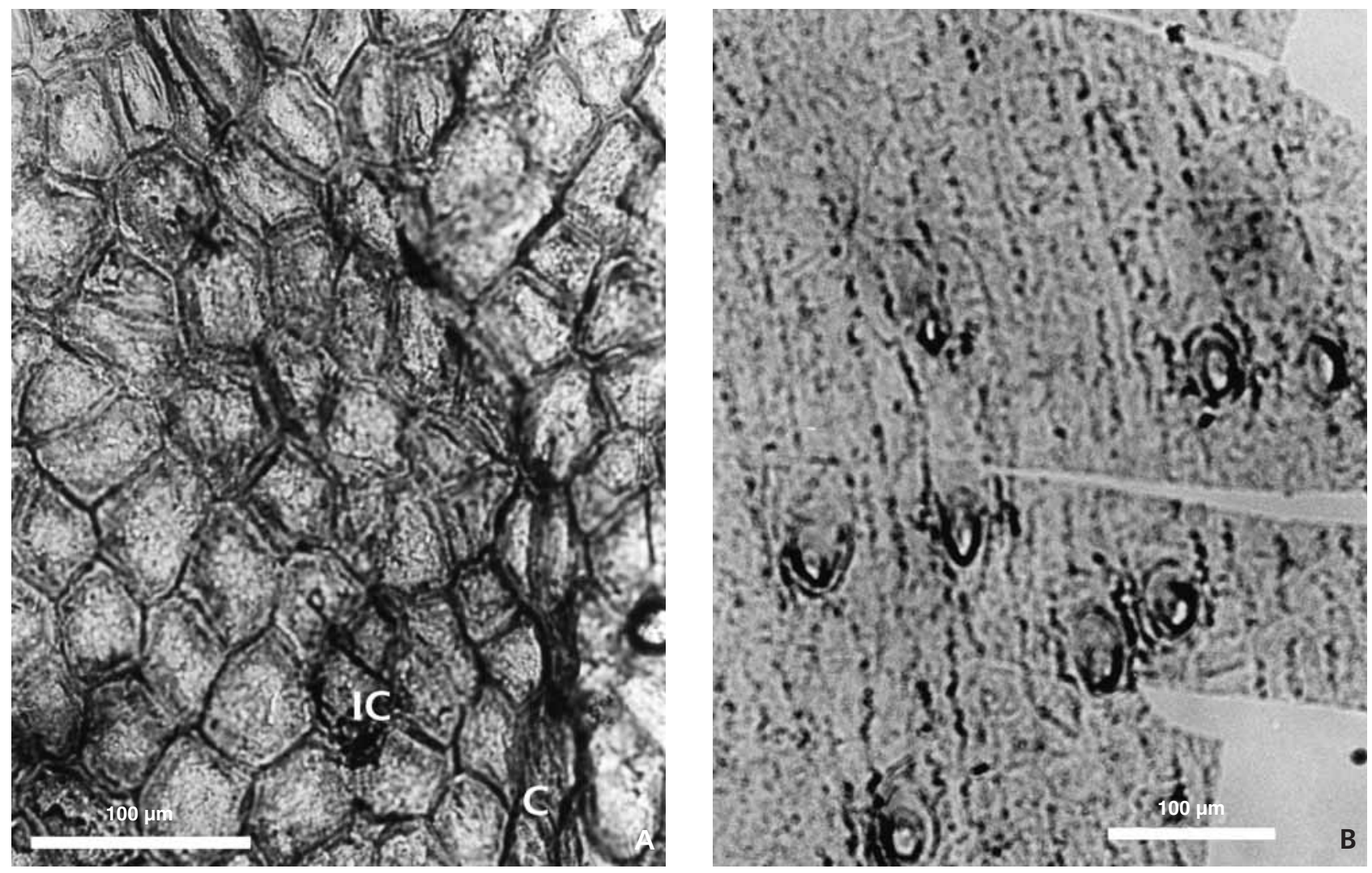

Figure 30. Linopteris obliqua (Bunbury) emend., epidermis; Sydney Coalfield, Cape Breton, Nova Scotia. • A - upper epidermal intercostal (IC) and costal (C) cell structures. 985-212b/6, Stubbart Seam (Prince Mine) (see Fig. 9). • B - lower epidermis with densely-spaced hair bases, (?)hydathodes. Stomatal details are not preserved. 982-201, Harbour Seam (Fig. 31B).

The systematic position of L. obliqua given below is based on the classification given in Anderson et al. (in press).

Class Cycadopsida Brongniart, 1843

Order Medullosales Corsin, 1960

Family Potonieaceae Halle, 1933

\section{Genus Linopteris Presl, 1838}

\section{Linopteris obliqua (Bunbury) Zeiller, 1899 emend. nov.}

Types. - Bunbury (1847) based his description of the species on three syntypes, identified in his hand-written "Catalogue of Fossil Plants in My Collection, 1850" as specimens 186, 187 and 188 . These specimens are photographically illustrated for the first time in the present paper (Fig. 25), and we designated specimen 186 as the lectotype, probably as intended by him. All three syntypes originated from strata associated with the middle Asturian (ex Westphalian D) Harbour Seam in the Sydney Coalfield, Cape Breton, Canada.

Diagnosis. - Frond up to $7 \mathrm{~m}$ long, axis $40 \mathrm{~mm}$ wide, at least quadripinnate, trifurcating, hairy and spiny (all axes), non- planar, winged, (?)laciniate lamina below main trifurcation. Penultimate pinna at least $200 \mathrm{~mm}$ long, with small (4 mm long) linguaeform to round intercalated pinnules that lack a midvein. Ultimate pinna, length variable, at least $200 \mathrm{~mm}$ long, $36 \mathrm{~mm}$ wide, shape linear, oblong, ovate-oblong, variable. Pinnules, densely hairy, polymorphic, asymmetric, round, linguaeform-subtriangular, slightly falcate-frequent form- narrow-elongate falcate, $4 \mathrm{~mm}$ to $27 \mathrm{~mm}$ long and 4 to $\mathrm{mm}$ to $19 \mathrm{~mm}$ wide. Margin curvilinear, parallel, non-parallel. Midvein, with 2 to 4 branches nearly reaching apex, flexuous, longitudinally finely striae and punctae, abaxially $80 \%$ length of pinnule, then replaced by areolae. Venation reticulate; areolate geometry variably elongate-hexagonal at midvein, changing occasionally to being septangular, 5-, 4-, or 3 -sided towards margin with increased frequency of crossover connections, generally showing acute-angled hats, straight-curvilinear sides; areolae $1.2 \mathrm{~mm}$ to $2.7 \mathrm{~mm}$ long, and $0.2 \mathrm{~mm}$ to $0.5 \mathrm{~mm}$ wide at midvein, decreasing at margin to 0.4 to $0.9 \mathrm{~mm}$ in length and $0.4 \mathrm{~mm}$ width; 5 to 10 areolae midvein to concave margin, where at margin elongate openended; line-of-areolae straight to slightly curved meeting margin acutely. Vein density ca 45 veins $/ 10 \mathrm{~mm}$ pinnule margin. Pinnule hypostomatic, stomatal type monocyclic, stomata randomly oriented, lower epidermis with hair bases. 


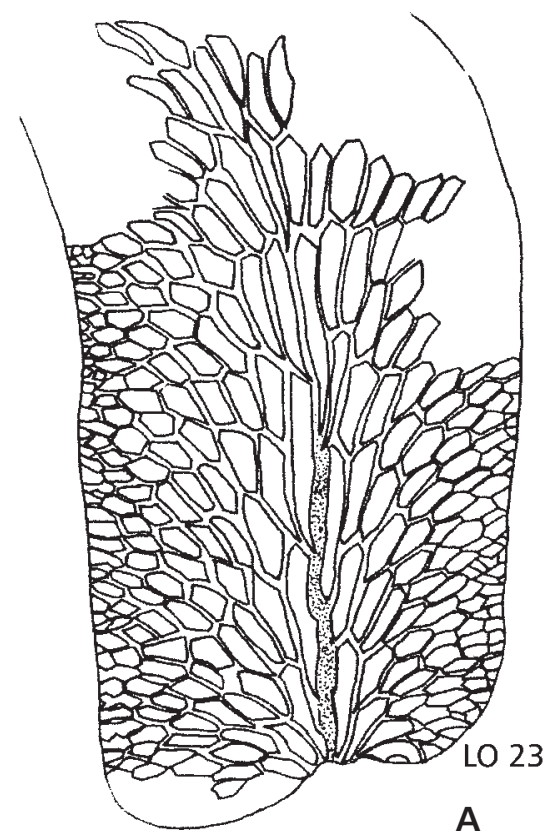

$5 \mathrm{~mm}$

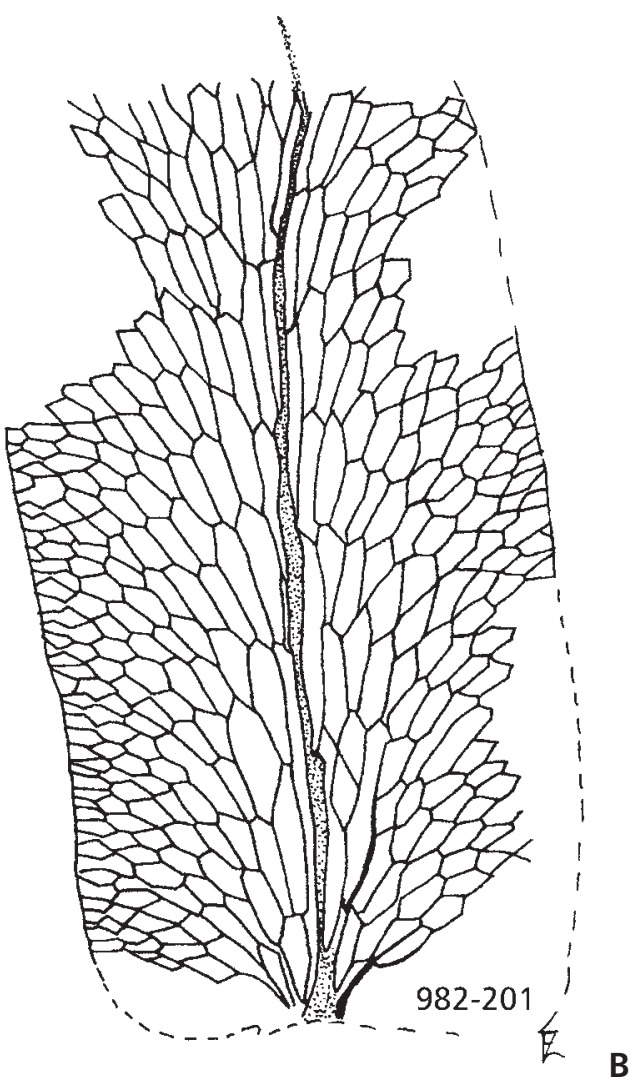

Figure 31. Linopteris obliqua (Bunbury) emend. Adaxial and abaxial midvein representations, type Harbour Seam, Sydney Coalfield, Cape Breton, Nova Scotia. $\bullet$ A - adaxial impression (not macerated), precision hand drawing showing the flexuous midvein (stippled) biased to less than $1 / 2$ the pinnule length, and the highly variable areolate geometry, particularly near the margin. Lo. 23. $・$ B - abaxial compression, precision hand drawing showing the flexuous midvein to about 5/10 of the pinnule length, but it continues to $c a$ 8/10 on the specimen 982-201.

Table 5. Typus characteristics of seven linopterid specimens: areolate geometry at the midvein.

\begin{tabular}{|c|c|c|c|c|c|c|}
\hline \multirow{2}{*}{$\begin{array}{l}\text { Criterion, see text (1) } \\
\text { Fig. } 32 \text { A-G }\end{array}$} & \multicolumn{3}{|c|}{ (2) } & (3) & (4) & (5) \\
\hline & $\begin{array}{l}\text { Proportion of parallelism } \\
\text { to the midvein }\end{array}$ & $\begin{array}{l}\text { Length } \\
\text { mm }\end{array}$ & Width & Hat geometry & Curvature & Pinnule base \\
\hline A - L. obliqua & $100 \%$ & 2.5 & 0.3 & triangular & slight & no rosette \\
\hline B - L. cf. obliqua & $40-100 \%$ & 2.6 & 0.3 & triangular & slight & small rosette \\
\hline $\mathrm{C}-$ L. regniezii & $50-80 \%$ & 4.1 & 0.5 & curvi acuminate & slight & incipient rosette \\
\hline $\mathrm{D}-\mathrm{L}$. neuropteroides var. minor & nearly $100 \%$ & 2.8 & 0.3 & triangular & slight & small rosette \\
\hline $\mathrm{E}-$ L. neuropteroides var. major & $10-40 \%$ & 8.3 & 0.7 & acute & slight & fully developed rosette \\
\hline $\mathrm{F}-$ L. neuropteroides var. minor & nearly $100 \%$ & 2.8 & 0.2 & triangular & none & no rosette \\
\hline $\mathrm{G}-$ L. brongniartii & $10-100 \%$ & 2.5 & 0.3 & triangular & slight & somewhat developed rosette \\
\hline
\end{tabular}

Remarks. - Cuticular data incorporated in the emendation is mostly from Barthel (1962), but also from our Fig. 30.

Bell (1938, p. 64) stated emphatically that Linopteris obliqua var. bunburi Bell has a rather "loose network of veins" (with some open form, neuropteroid areolae). Open-ended areolae (other than marginal ones), or neuropteroid-like areolate venation of any kind, however, have not been observed in the present samples, including the juvenile areolae. More generally, linopterid foliage with the "loose network of veins" mentioned by Bell (1938) has not been observed in the large sample size from Sydney Coalfield that was studied preparatory for this paper. Moreover, re-examination of the material published by Zodrow \& McCandlish (1978) equally showed no such vein characteristics. In a future paper on linopterid typification, the position of Bell's species will be clarified.

The most important distinguishing characteristics of L. obliqua foliage are that the first row of areolae are strictly lengthwise parallel to the midvein, and do not form a rosette-like pattern at the base of the midvein. Areolae at 


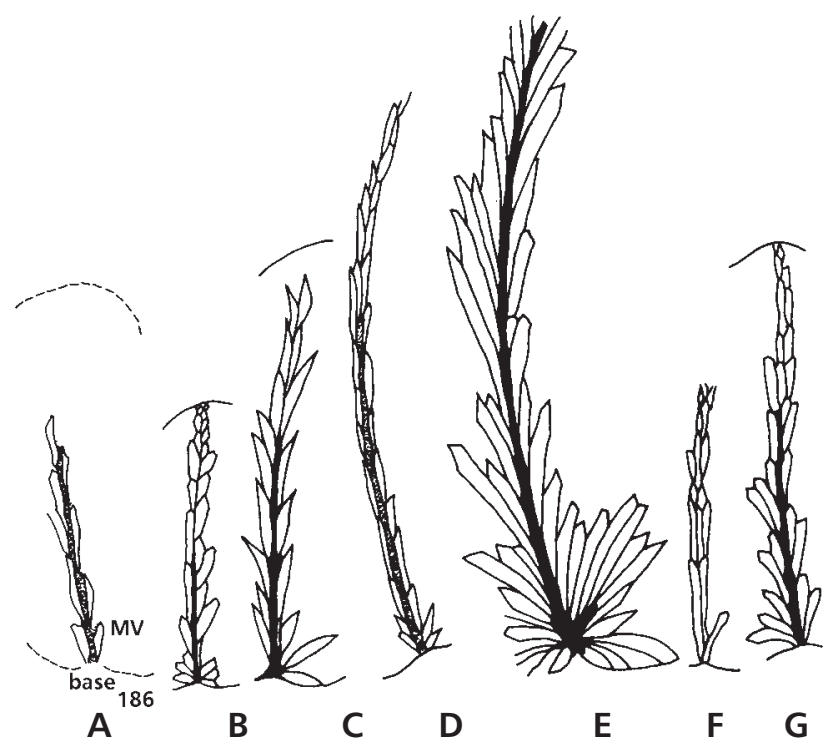

Figure 32. Selected linopterid types and their typus architecture at the midvein. $\bullet$ A - lectotype 186 . $\bullet B-G$ - unaltered original figured by the authors. - B - L. cf. obliqua (Bunbury), Laveine's interpretation (1967a, fig. 47). • C - L. regniezii Laveine (1967a, fig. 48; 1967b). D - L. neuropteroides (Gutbier) var. minor, Zeiller's interpretation (1899, fig. 10). • E - L. neuropteroides (Gutbier) Zeiller var. major (Remy \& Remy 1977, Bild 147). • F - L. neuropteroides (Gutbier) var. minor, Potonié's interpretation (1904, Lief. II, 28, 1). • G - L. brongniartii (Zeiller 1878, Pl. CLXV, fig. 2).

the midvein are elongate-hexagonal with triangular hats, or basal tail, less than $3 \mathrm{~mm}$ long and $\mathrm{ca} 0.4 \mathrm{~mm}$ wide. Thereafter, they are variable in size and shape, strictly closed over the lamina, but consistently elongate-open at the margin. Pinnate characteristics include paripinnate terminals, spiny rachis, small to medium-sized spiny? pinnules, and $4 \mathrm{~mm}$ to $11 \mathrm{~m}$ long intercalated pinnules.

The biostratigraphic range of L. obliqua (Bunbury) emend. is stable in the Sydney Coalfield, Nova Scotia, as outlined by Zodrow \& McCandlish (1978, Table 5).

\section{Conclusion}

For the first time, we provide empirical evidence for reconstructing the L. obliqua plant, including our initial understanding of the complex frond (Fig. 34). It appears to have been a medium-tall arborescent plant with a trunk $c a 0.2 \mathrm{~m}$ wide. Fronds ca $7 \mathrm{~m}$ long probably had ovules attached singly to the base of the petiole, although this still requires confirmation. All orders of rachis were covered in punctae of variable sizes, although further cuticular and phytochemical work will be needed to determine the function of these trichomes. We found no new evidence of attached pollen-organs, although based on previously published evidence they were probably borne in complex clusters, attached either directly to the cauline axis or to the pri-

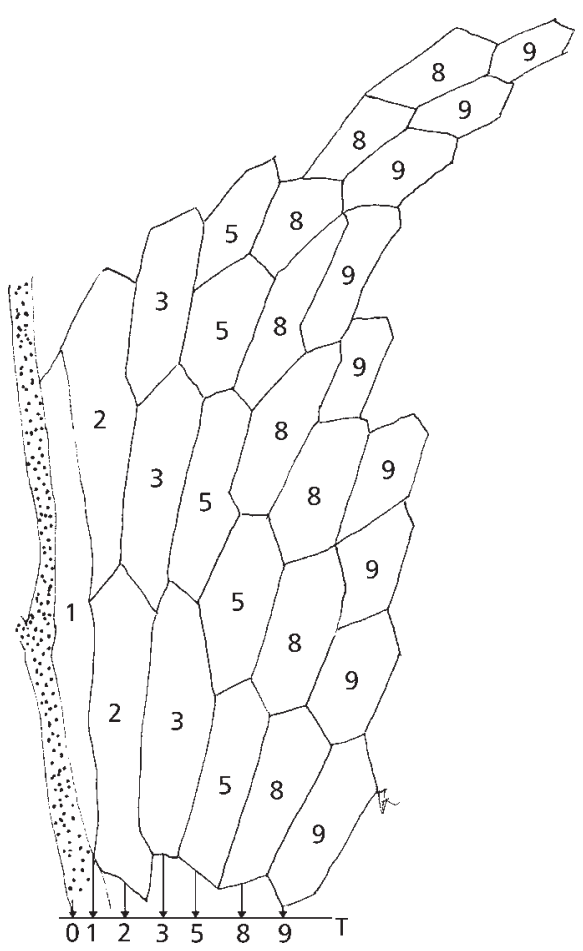

Figure 33. Empirical derivation of the terms for Fibonacci's Series. 982-201, abaxial surface, Harbour Seam, Sydney Coalfield, Cape Breton, Nova Scotia; T, derived from summing the number of vertical areolae, represents the terms (see text).

mary rachis/petiole of the frond (e.g., Laveine et al. 1991). Current evidence suggests that the plants belonged to a family that arose in China in Early Carboniferous times and migrated westwards along southern Laurasia during Late Carboniferous times. The Sydney Coalfield in Nova Scotia seems to have been close to the western limit of this migration of the genus.

The specimens described are small relative to the 7-m probable size of the whole frond. Nevertheless, they provide the first concrete evidence for highly polymorphic ultimate foliar segments, with rapid changes in pinnule shapes being observable even in relatively small specimens. L. obliqua foliage generally cannot be objectively distinguished from other linopterid morphospecies by only one parameter. However, the probability of successful distinction increases when the typus-parameters are combined with morphological parameters of the pinnae. To this end, we propose new parametric variables, which are rooted in geometrical concepts that best mimic the variable geometry of the two-dimensional vein-reticulation. We believe that objective recognition of the linopterid typus, coupled with a geometrical-statistical analysis of the morphological data, would be sufficient for the specific determination even of single pinnules. However, because of the current absence of such data for most other Linopteris species, we have not been able to make detailed comparisons with those species. 


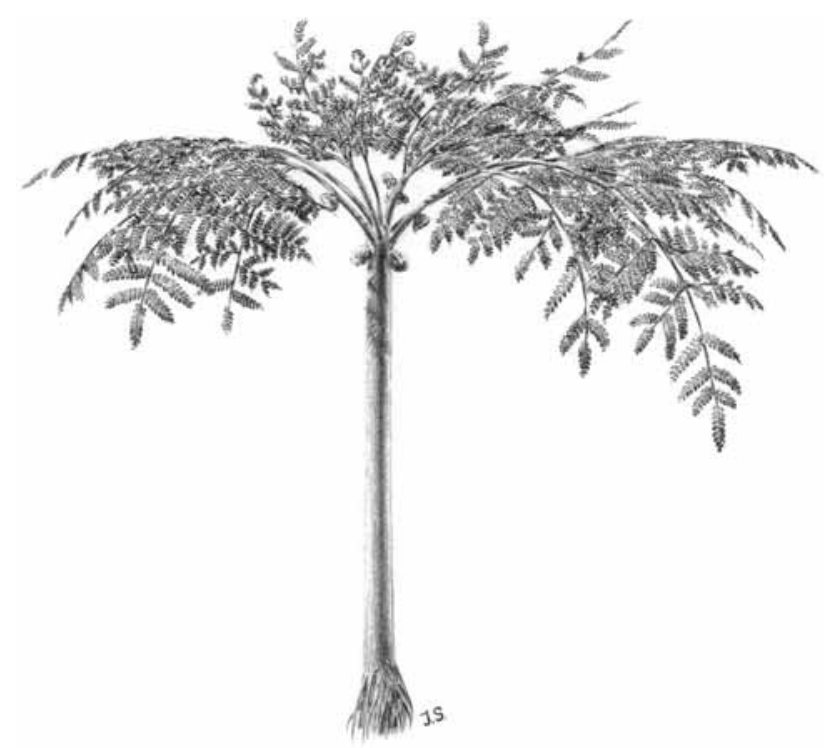

Figure 34. Reconstructed Linopteris plant showing salient features mentioned in the text.

We suggest from indirect evidence that the reproductive biology of the L. obliqua plant was characterized by periodic short-lived intervals of seed production, maybe triggered by ecological stress. These times of seed-production coincided with the mass shedding of the photosynthetic pinnules so as to redirect resources to reproduction.

\section{Acknowledgement}

ELZ is indebted to R.G. West for help in 1983 during his visit to the Botany School, University of Cambridge, and for permission to photograph the types of L. obliqua. Thanks also go to D. Pemberton (Sedgwick Museum, Cambridge) for the loan of Bunbury's specimen 186 (2004). J.-P. Laveine (Lille) is thanked for his expertise and technical advice, copiously offered and gratefully accepted, concerning hypothetical frond interpretations, the nature of the trifurcate linopterid frond, and for making available to us research literature on linopterid fructifications. We also acknowledge C. Shute (The Natural History Museum, London) for advice on leaf abscission in tropical plants. The new bipinnate foliage documented in this paper was collected in September 2004 by A. McKay, and the juvenile foliage by G. Walker, both from Cape Breton, Nova Scotia, to whom we are most grateful for making the material available to us. The work has been made possible by open-pit mine owners and operators Tom Brogan and Sons, Cape Breton, Nova Scotia who promoted, and continue to actively assist collecting efforts by ELZ, ever since 1973. Anonymous journal reviewers, and co-editor J. Pšenička, are cordially thanked for editorial advise and effort. ELZ is grateful to the Natural Science and Engineering Research Council of Canada for funding research on Sydney's Carboniferous-age macrofloras. The authors thank J. Svoboda for the art work of the reconstructed Linopteris plant.

\section{References}

AdDicotT, F.T. 1982. Abscission. 369 pp. University of California Press, Berkeley CA.

Anderson, J., Anderson, H. \& CleAl, C.J. In press. A brief history of the gymnosperms. National Botanical Institute, Pretoria.

BARTHEL, M. 1962. Epidermisuntersuchungen an einige inkohlten Pteridospermenblättern des Oberkarbons und Perms. Geologie Beiheft 11(33), 1-140.

BeLl, W.A. 1938. Fossil flora of Sydney Coalfield, Nova Scotia. Geological Survey of Canada Memoir 215, 1-334.

BOCHEŃSKI, T. 1960. Evolution of pinnule venation in the Carboniferous seed ferns Alethopterides (Alethopteris and Lonchopteris) and the meaning of pinnule (V)enation analysis for diagnosis of species. Prace Instytut Geologiczny, Warszowa 20, 1-42.

Brongniart, A. 1843. Énumeration des genres de plantes cultivés au Muséum d'Histoire Naturelle de Paris suivant l'ordre établi dans l'Ecole de Botanique en 1843. 136 pp. Masson, Paris.

Brown, R. 1850. Section of the Lower Coal-measures of Sydney Coalfield, in the Island of Cape Breton. Quarterly Journal of the Geological Society of London 6, 115-133.

Buisine, M. 1961. Contribution a l'étude de la flore du terrain houiller. Les Aléthoptéridées du Nord de la France. Études Géologiques pour l'Atlas de Topographie Souterraine, 1-317.

BunBury, C.J.F. 1847. On fossil plants from the Coal Formation of Cape Breton. Quarterly Journal of the Geological Society of London 3, 423-438.

CARPENTIER, A. 1911. Note sur les graines trouvées avec Linopteris sub-Brongniarti Grand'Eury dans le houiller du Pas-deCalais. Annales de la Société Géologique du Nord 60, 291-294.

Chaloner, W.G. 1986. Reassembling the whole fossil plant, and naming it, 67-78. In SPICER, R.A. \& THOMAS, B.A. (eds) Systematic and taxonomic approaches in palaeobotany. The Systematics Association, Special Volume No. 31. Linnean Society of London, Academic Press, London.

Cleal, C.J. \& Laveine, J.-P. 1988. The juvenile frond of the Middle Carboniferous pteridosperm Paripteris Gothan. Geobios 21(2), 245-250.

Cleal, C.J. \& Shute, C.H. 1995. A synopsis of neuropteroid foliage from the Carboniferous and Lower Permian of Europe. Bulletin of the British Museum (Natural History), Geology Series $51,1-52$.

CLEAL, C.J. \& ZODROW, E.L. 1989. Epidermal structure of some medullosan Neuropteris foliage from the Middle and Upper Carboniferous of Canada and Germany. Palaeontology 32, 837-882.

Corsin, P. 1960. Classification des Ptéridophytes et des Ptéridospermophytes du Carbonifère. Bulletin de la Société Géologique de France, Série 7(2), 566-572.

CrAmér, H. 1945. Mathematical methods of statistics. 575 pp. Princeton University Press, Princeton.

CRANE, P.R. 1984. A re-evaluation of Cercidiphyllum-like plant fossils from the British early Tertiary. Botanical Journal of the Linnaean Society 89, 199-230.

Crookall, R. 1959. Fossil plants of the Carboniferous rocks of Great Britain [Second Section]. Part 2. Memoirs of the Geological Survey of Great Britain, Palaeontology 4, 85-216. 
DARRAH, W.C. 1969. A critical review of the Upper Pennsylvanian floras of Eastern United States with notes on the Mazon Creek Flora of Illinois. 220 pp. W.C. Darrah, Gettysburg, Pennsylvania.

DELEVORYAS, T. \& TAYLOR, T.N. 1969. A probable pteridosperm with eremopterid foliage from the Allegheny Group of northern Pennsylvania. Postillia 133, 1-14.

DrinnAN, A.N. \& CRANe, P.R. 1994. A synopsis of medullosan pollen organs from the Middle Pennsylvanian Mazon Creek flora of northeastern Illinois. Review of Palaeobotany and Palynology 80, 235-257.

Gibling, M.R. \& BIRD, D.J. 1994. Late Carboniferous cyclothems and alluvial palaeovalleys in the Sydney Basin, Nova Scotia. Geological Society of America Bulletin 106, 105-117.

Gothan, W. 1941. Paläobotanische Mitteilungen 5-7. Paläontologische Zeitschrift 22, 421-438.

Greuter, W., McNeill, J., Barrie, F.R., Burdet, H.M., DeMOUlin, V., Filgueiras, T.S., Nicolson, D.H., Silva, P.C., Skog, J.E., Trehane, P., Turland, N.J. \& Hawksworth, D.L. 2000. International Code of Botanical Nomenclature (Saint Louis Code). 474 pp. Koeltz Scientific Books, Königstein.

HALle, T.G. 1933. The structure of certain fossil spore-bearing organs believed to belong to pteridosperms. Kungliga Svenska Vetenskapsa-kademiens Handlingar, Series 3(12), 1-103.

HegGie, M. \& Zodrow, E.L. 1994. Fractal lobatopterid frond (Upper Carboniferous marattialean tree fern). Palaeontographica, Abteilung B 232, 35-37.

JoNGMANS, W.J. 1952. The female fructification of Sphenopteris hoeninghausii and the supposed relation of this species to Crossotheca. The Palaeobotanist 1, 267-274.

JostEN, K.-H. 1962. Neuropteris semireticulata, eine neue Art als Bindeglied zwischen Neuropteris und Reticulopteris. Palaeontologische Zeitschrift 36(1/2), 33-45.

Kolmogorov, A.N. 1956. Foundations of the theory of probability. 84 pp. Chelsea Publishing Company, New York [second English translation].

KRAUSKOPF, K.B. 1979. Introduction to geochemistry. 617 pp. McGraw-Hill Book Co., New York [2 $2^{\text {nd }}$ ed.].

KrINGS, M. \& KERP, H. 1998. Epidermal anatomy of Barthelopteris germarii from the Upper Carboniferous and Lower Permian of France and Germany. American Journal of Botany 85, 553-562.

KRUMBEIN, W.C. \& GRAYBILL, F.A. 1965. An introduction to statistical models in geology. 475 pp. McGraw-Hill, New York.

LAVEINE, J.-P. 1967a. Contribution a l'étude de la flore du terrain houiller. Les Neuroptéridées du Nord de la France. Études Géologiques pour l'Atlas de Topographie Souterraine 1(5), $1-344$.

LAVEINE, J.-P. 1967b. Supplement a l'étude des Neuroptéridées du Nord de la France. Figuration complementaire du Linopteris regniezi Laveine. Annales de la Société Géologique du Nord, Lille LXXXVII, 211.

LAVEINE, J.-P. 1971. Sporomorphes in situ de quelques Parispermées (Neuroptéridées) du Carbonifère. Annales de la Société Géologique du Nord 91, 155-173.

LAVEINE, J.-P. 1989. Fossilisation and systematics of Carboniferous compression floras. Compte rendu XI ${ }^{\text {th }}$ International Congress of Stratigraphy and Carboniferous Geology 1987(3), 124-127.
LAVEINE, J.-P. 1997. Synthetic analysis of the Neuropterids, their interest for the decipherment of Carboniferous palaeogeography. Review of Palaeobotany and Palynology 95, 155-189.

LaVeine, J.-P., Lemoigne, Y. \& Zhang, S. 1991. L'organisation des appareils reproducteurs dans le genre Paripteris Gothan 1941 (Ptéridospermée du Carbonifère). Comptes rendus de l'Académie des Sciences, Paris, Série II 312, 573-580.

LAVEINE, J.-P., Lemoigne, Y. \& Zhang, S. 1993. General characteristics and paleobiogeography of the Parispermaceae (Genera Paripteris Gothan and Linopteris Presl), pteridosperms from the Carboniferous. Palaeontographica, Abteilung B 230, 81-139.

LAveine, J.-P., Zhang, S. \& Lemoigne, Y. 1989. Global paleobotany, as exemplified by some upper Carboniferous pteridosperms. Bulletin de la Société belge de Géologie 98(2), 115-125.

Laveine, J.-P., Zhang, S., Liu, L., ZhaO, B., Pan, X., CaO, J., LiU, Z. \& Lemoigne, Y. 2003. The Late Carboniferous flora of the Hulstai area (Alxa Zuoqi Banner; Inner Mongolia Autonomous Region, North China). Revue de Palaéobiologie 22(2), 661-716.

Pfefferkorn, H.W., Gillespie, W.H., Resnik, D.A. \& SCheIHING, M.H. 1984. Reconstruction and architecture of medullosan pteridosperms (Pennsylvanian). The Mosasaur 2, 1-8.

PotoniÉ, H. 1904. Abbildungen und Beschreibungen fossiler Pflanzen-Reste der palaeozoischen und mesozoischen Formationen. Lieferung II. 28, 1; 29. 5 pp. Königlich Preussischen Geologischen Landesanstalt und Bergakademie, Berlin.

PRESL, C.B. 1838. In STERnBERG, K.M. vON 1820-1838 Versuch einer Geognostisch-botanischen Darstellung der Flora der Vorwelt. I - 220 pp., pls I-LIX, A-E; II - 220 pp., pls I-LXVIII, A, B, G. Haase Sohne Ed., Prag.

PŠENIČKA, J. 2005. Taxonomy of Pennsylvanian-Permian ferns from the coal basis in the Czech Republic and Canada. $185 \mathrm{pp}$. Unpublished $\mathrm{PhD}$ thesis, Charles University, Prague.

Remy, W. \& Remy, R. 1977. Die Floren des Erdaltertums. 468 pp. Verlag Glückauf GMBH, Essen.

Retallack, G.J. \& Dilcher, D.L. 1988. Reconstruction of selected seed ferns. Annals of the Missouri Botanical Garden 75(3), 1010-1057.

RiCHARDS, P.W. 1952. The tropical rain forest. An ecological study. 450 pp. Cambridge University Press, Cambridge.

Roth-Nebelsick, A., Uhl, D., Mosbrugger, V. \& Kerp, H. 2001. Evolution and function of leaf venation architecture: a review. Annals of Botany 87, 663-566.

SCHINDEWOLF, O.H. 1980. Grundfragen der Paläontologie. 506 pp., 32 pls. Arno Press, New York [reprint of 1950 edition].

SCHOPf, J.M. 1975. Modes of fossil preservation. Review of Palaeobotany and Palynology 20, 27-53.

SEILACHER, A. 1982. General remarks about event deposits, 161-174. In Einsele, G. \& SeIlacher, A. Cyclic and Event Stratification. Springer Verlag, New York.

Shute, C.H. \& CleAL, C.J. 1986. Palaeobotany in museums. Geological Curator 4, 553-559.

Shute, C.H. \& Cleal, C.J. 2002. Ecology and growth habit of Laveineopteris: a gymnosperm from the Late Carboniferous tropical rain forests. Palaeontology 45, 943-972.

SingH, K.P. \& KushwaHA, C.P. 2006. Diversity of flowering and fruiting phenology of trees in a tropical deciduous forest in India. Annals of Botany 97, 265-276.

SмiтH, D.E. 1958. History of mathematics. Vol. 1 General survey 
of the history of elementary mathematics. 596 pp. Dover Publication, New York.

StidD, B.M., Oestry, L.L. \& PhilliPs, T.L. 1975. On the frond of Sutcliffia insignis var. tuberculata. Review of Palaeobotany and Palynology 20, 55-66.

TAYLOR, T.N. 1965. Palaeozoic seed studies: A monograph of the American species of Pachytesta. Palaeontographica Abteilung B 117, 1-46.

Tenchov, Y.G. 2004. The genus Lonchopteris Brongniart in the Dobrudzha Carboniferous Basin, Bulgaria. Geologica Balcanica 34, 97-104.

Tenchov, Y.G. \& Popov, A.B. 1987. The genus Linopteris Presl (Late Carboniferous) in Dobrudza Coal Basin. Geologica Balcanica 17(1), 15-32.

Tenchov, Y.G. \& Popov, A.B. 1991. Morphogenetic transition between genera Neuropteris (Brongniart) and Reticulopteris Gothan in Dobrudza Coal Basin. Geologica Balcanica 20(6), 41-51.

Tryon, R.M., Tryon, A.F. \& Kramer, K.U. 1990. Pteridaceae. Pteridoideae, 230-256. In KRAMER, K.U. \& GREEN, P.S. (eds) The families and genera of vascular plants. Vol. I. Pteridophytes and Gymnosperms. Springer-Verlag, Berlin.

UHL, D. \& MosbrugGer, V. 1999. Leaf venation density as a climate and environmental proxy: a critical review and new data. Palaeogeography, Palaeoclimatology, Palaeoecology 149(1-4), $15-26$.

WAGNER, W.H. 1979. Reticulate veins in the systematics of modern ferns. Taxon 28, 87-95.

WILSON, M.V.H. 1988. Taphonomic processes: Information loss and information gain. Geoscience Canada 15(2), 131-145.

WNuk, C. \& PfeFferkoRn, H.H. 1984. The life habits and palaeoecology of Middle Pennsylvanian medullosan pteridosperms based on in situ assemblage from the Bernice Basin (Sullivan County, Pennsylvania, U.S.A.). Review of Palaeobotany and Palynology 41, 329-351.

ZEILLER, R. 1878. Végétaux fossils du terrain houiller de la France. Explication de la Carte Géologique de la France 4, $1-185$.

ZEILLER, R. 1886. Bassin houiller de Valenciennes, description de la flore fossile (Atlas). 114 pls. Études des Gîtes Mineraux de la France, Paris.

ZEILLER, R. 1899. Étude sur le flore fossile du Bassin houiller d'Héraclée. Mémores de la Société Géologique de la France, Paléontologie 21, 1-91.

Zhang, S., HuO, F., CAO, J., Liu, Z., Laveine, J.-P. \& Lemoigne, Y. 1992. The Carboniferous flora of the Zhongning District, Ningxia Region, North China. Revue de Palaéobiologie 6(1), 1-93.

ZimmermanN, W. 1952. Main results of the "Telome Theory". The Palaeobotanist 1, 456-470.

ZODROw, E.L. 1973. Contribution to the informal theory of geological mineral sample. $321 \mathrm{pp}$. Unpublished $\mathrm{PhD}$ thesis, University of Western Ontario, London.

ZODROw, E.L. 1983. Some geochemical aspects of sedimentary rocks in proximity of coals, Sydney Coalfield (Upper Carboniferous), Cape Breton Island, Nova Scotia, Canada. International Journal of Coal Geology 2, 299-320.

Zodrow, E.L. 1985. Odontopteris Brongniart in the Upper Car- boniferous of Canada. Palaeontographica, Abteilung B 196, 79-110.

ZoDrow, E.L. 2002. The "medullosalean forest" at the Lloyd Cove Seam (Pennsylvanian, Sydney Coalfield, Nova Scotia, Canada). Atlantic Geology 38, 177-195.

ZoDROw, E.L. 2004. Note on singly and multiply-attached trigonocarpolean ovules (Medullosales, Pennsylvanian Sydney Coalfield. Canada). Atlantic Geology 40, 197-206.

ZODROw, E.L. 2005. Colliery and surface hazards through coal-pyrite oxidation (Pennsylvanian Sydney Coalfield, Nova Scotia, Canada). International Journal of Coal Geology 64, 145-155.

ZoDROW, E.L. 2007. Reconstructed tree fern Alethopteris zeilleri (Carboniferous, Medullosales). International Journal of Coal Geology 69, 68-89.

Zodrow, E.L. \& BANERJEe, S.K. 1993. Modeling the lobatopterid frond (tree fern, Carboniferous). Compte Rendus, Douzième Congrès International de la Stratigraphie et Géologie du Carbonifère et Permien (Buenos Aires) 1, 159-172.

Zodrow, E.L. \& CLEAL, C.J. 1985. Phyto- and chronostratigraphical correlations between the late Pennsylvanian Morien Group (Sydney, Nova Scotia) and the Silesian Pennant Measures (south Wales). Canadian Journal of Earth Sciences 22, 1465-1473.

Zodrow, E.L. \& ClEAL, C.J. 1988. The structure of the Carboniferous pteridosperm frond Neuropteris ovata Hoffmann. Palaeontographica, Abteilung B 208, 105-124.

Zodrow, E.L. \& ClEAL, C.J. 1993. The epidermal structure of the Carboniferous gymnosperm frond Reticulopteris. Palaeontology 36(1), 65-79.

ZODROW, E.L. \& CLEAL, C.J. 1998. Revision of the pteridosperm foliage Alethopteris and Lonchopteridium (Upper Carboniferous), Sydney Coalfield, Nova Scotia, Canada. Palaeontographica, Abteilung B 247, 65-122.

Zodrow, E.L., Cleal, C.J. \& ThOmas, B.A. 2001. An amateur's guide to coal-plant fossils on Cape Breton Island, Nova Scotia, Canada. 112 pp. University College of Cape Breton Press, Sydney NS.

ZodRow, E.L. \& MCCANDLISH, K. 1978. Distribution of Linopteris obliqua in the Sydney Coalfield of Cape Breton, Nova Scotia. Palaeontographica, Abteilung B 168, 1-16.

Zodrow, E.L. \& MCCANDLISH, K. 1980. On a Trigonocarpus species attached to Neuropteris (Mixoneura) flexuosa from Sydney Coalfield, Cape Breton Island, Nova Scotia, Canada. Review of Palaeobotany and Palynology 30, 57-66.

ZODROW, E.L. \& MASTALERZ, M. 2001. Chemotaxonomy for naturally macerated tree-fern cuticles (Medullosales and Marattiales), Carboniferous Sydney and Mabou Sub-Basins, Nova Scotia, Canada. International Journal of Coal Geology 47, 255-275.

Zodrow, E.L., Mastalerz, M., Orem, W.H., ŠIMU゚neK, Z. \& BASHFORTH, A.R. 2000. Functional groups and elemental analyses of cuticular morphotypes of Cordaites principales (Germar) Geinitz, Carboniferous Maritimes Basin, Canada. International Journal of Coal Geology 45, 1-19.

Zodrow, E.L. \& VAsey, G.M. 1986. Mabou Mines Section: Biostratigraphy and correlation (Pennsylvanian Pictou Group, Nova Scotia, Canada). Journal of Paleontology 60(2), $208-232$. 